Florida International University FIU Digital Commons

7-26-2005

\title{
Paleolimnological investigation of recent sediments from Lake Monroe, Florida, USA.
}

Bryan P. Carroll

Florida International University

DOI: $10.25148 /$ etd.FI14052589

Follow this and additional works at: https:// digitalcommons.fiu.edu/etd

Part of the Environmental Sciences Commons, and the Geology Commons

\section{Recommended Citation}

Carroll, Bryan P., "Paleolimnological investigation of recent sediments from Lake Monroe, Florida, USA." (2005). FIU Electronic Theses and Dissertations. 2059.

https://digitalcommons.fiu.edu/etd/2059 
Miami, Florida

LAKE MONROE, FLORIDA, USA

\author{
A thesis submitted in partial fulfillment of the \\ requirements for the degree of \\ MASTER OF SCIENCE \\ in \\ GEOSCIENCES \\ by \\ Bryan P. Carroll
}

2005 
To: Interim Dean Mark D. Szuchman

College of Arts and Sciences

This thesis, written by Bryan P. Carroll, and entitled Paleolimnological Investigation of Recent Sediments From Lake Monroe, Florida, USA, having been approved in respect to style and intellectual content, is referred to you for judgment.

We have read this thesis and recommend that it be approved.

Renè M. Price

Evelyn E. Gaiser

Leonard J. Scinto

William T. Anderson, Major Professor

Date of Defense: July 26, 2005

The thesis of Bryan P. Carroll is approved.

Interim Dean Mark D. Szuchman College of Arts and Sciences

Dean Douglas Wartzok University Graduate School

Florida International University, 2005 


\section{ACKNOWLEDGMENTS}

I wish to express extreme gratitude towards my committee members for not only agreeing to be a part of this thesis project, but more importantly, for their unconditional guidance and patience throughout the proposal, research, and writing process. Without them, this document would not have been possible. I know that I am a better student, researcher, and writer because of them.

Additionally, I would like to acknowledge those people outside of my committee, who were gracious enough to offer their help. Thank you to Dean Whitman and Maria Martinez for sharing their GIS knowledge, Jaime Haberer for her help with the nutrient

analysis, Diana Johnson for her general laboratory help and sample preparation, and Mark Kershaw and Romy Lahera for their collective isotope analysis work. This study was funded in part by the St. Johns River Water Management District and Troy Keller. Interpretations and conclusions are not necessarily those of the supporting agency. Thank you all for your time. 


\section{ABSTRACT OF THE THESIS}

PALEOLIMNOLOGICAL INVESTIGATION OF RECENT SEDIMENTS FROM

LAKE MONROE, FLORIDA, USA

by

Bryan P. Carroll

Florida International University, 2005

Miami, Florida

Professor William T. Anderson, Major Professor

Sediments recovered in October 2003 from Lake Monroe, a hypereutrophic lake in central Florida, have been sub-sampled and analyzed for $\delta^{13} \mathrm{C}, \delta^{15} \mathrm{~N}, \mathrm{TC}, \mathrm{TIC}, \mathrm{TOC}$, and TN. A chronology of bulk sediment and nutrient accumulation was established by radiometric analyses $\left({ }^{210} \mathrm{~Pb},{ }^{137} \mathrm{Cs}\right.$, and $\left.{ }^{14} \mathrm{C}\right)$, to aid in evaluating spatial and temporal patterns within the lake since development in the watershed began. A continuous 100year sediment record from Lake Monroe shows significant changes in production, sedimentation, and nutrient abundance following land settlement in the mid 1800's. Sediment nutrient and isotopic analyses demonstrate an increasing trend in nutrients, $\delta$ values, and sediment accumulation relative to pre-disturbance deposits. The sediment geochemical record suggests increased production, possible nutrient limitation, and shifts in primary producer communities through time. The data demonstrates that these historic increases are a direct result of watershed development, land use alterations, and increased nutrient loading within the basin. 


\section{TABLE OF CONTENTS}

1. INTRODUCTION.

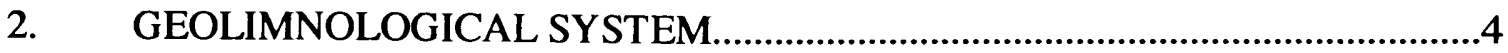

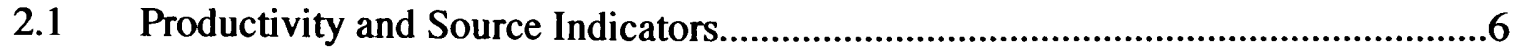

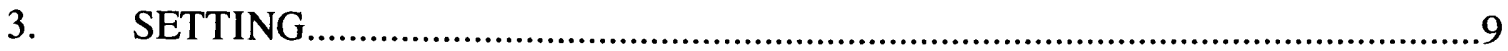

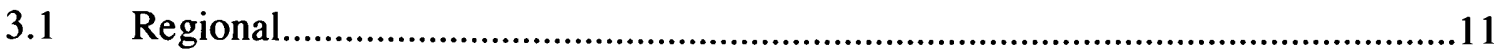

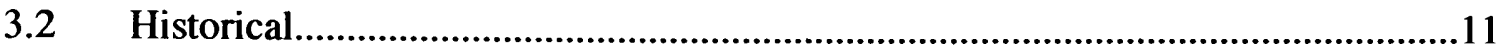

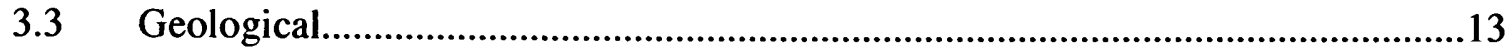

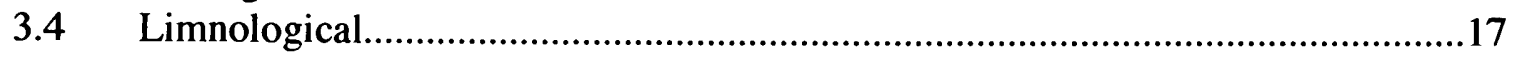

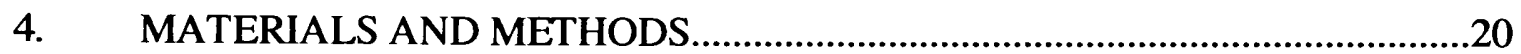

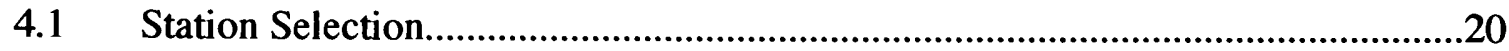

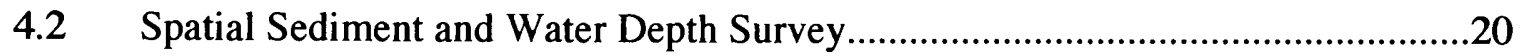

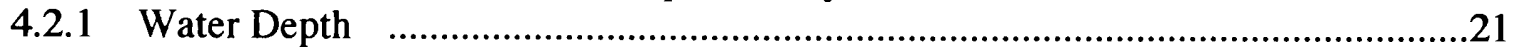

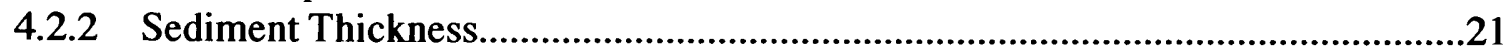

4.2.3 Floc Thickness and Sediment Collection........................................................22

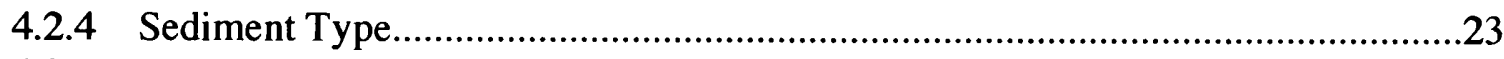

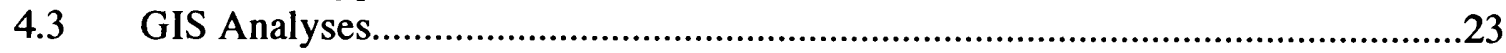

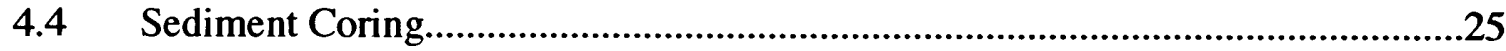

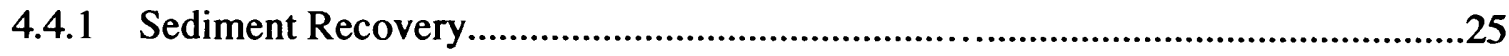

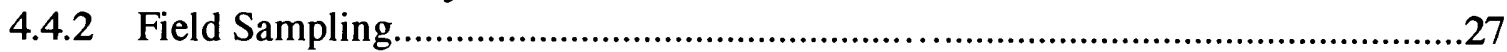

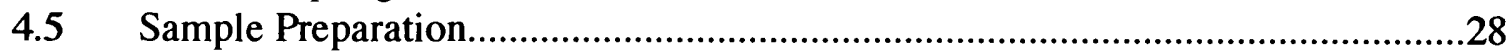

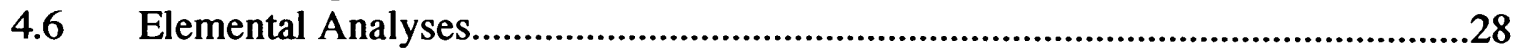

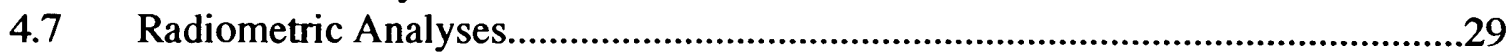

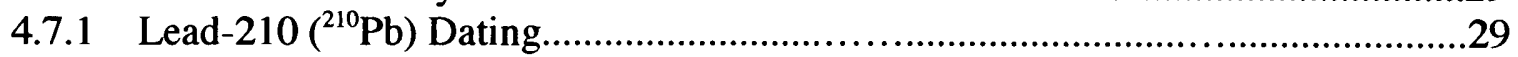

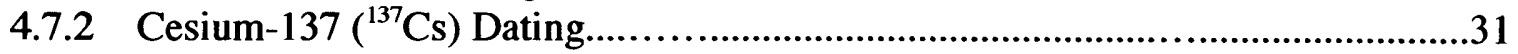

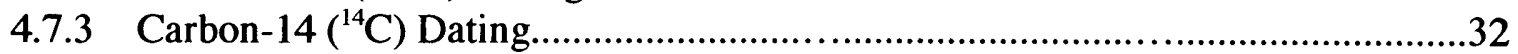

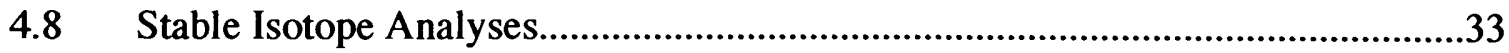

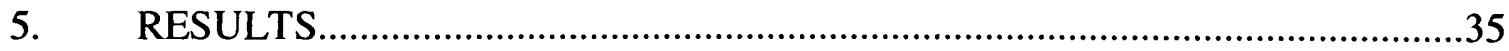

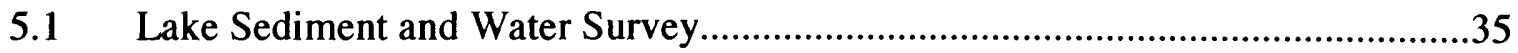

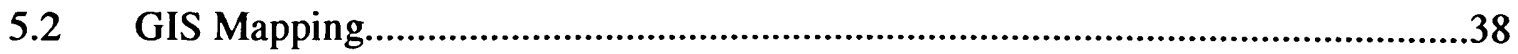

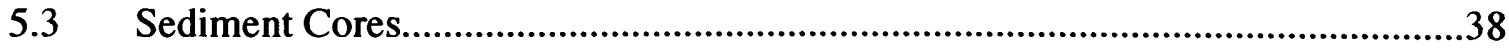

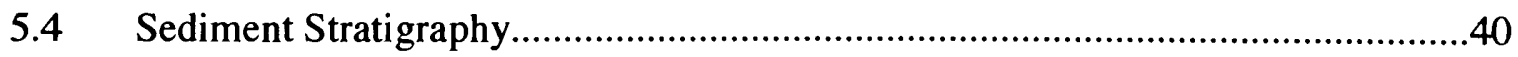

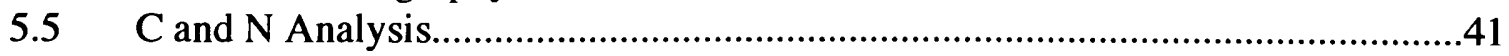

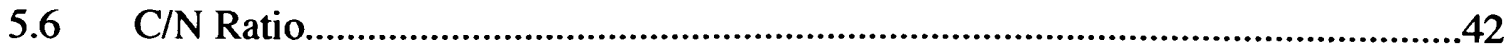

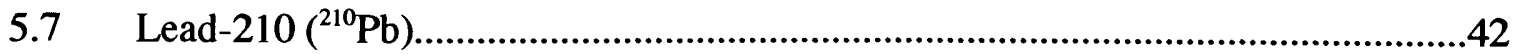

5.7.1 ${ }^{210} \mathrm{~Pb}$ Calculated dates and sediment Mass Accumulation Rate (MAR).................48

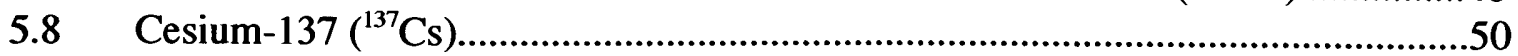

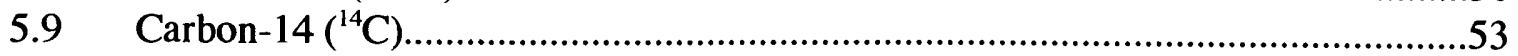




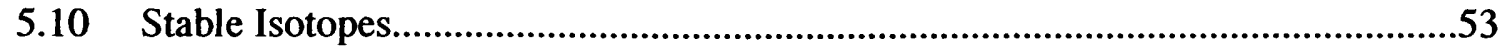

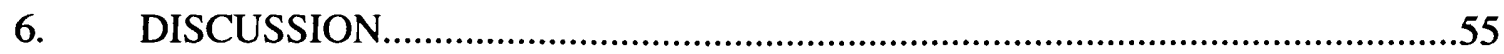

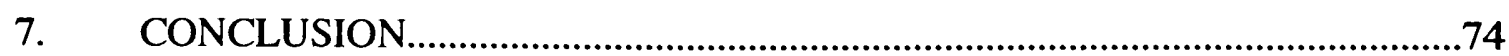

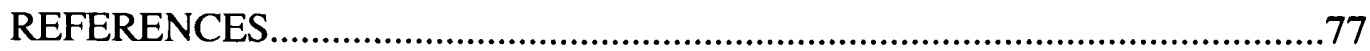

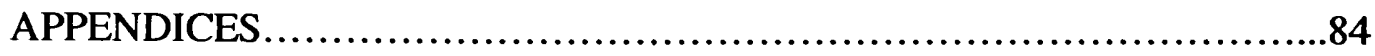




\section{LIST OF TABLES}

TABLE

PAGE

1. Lake Monroe physical dimensions. Water depth measurements recorded in June, 2003.

2. Lake Monroe sediment chemistry statistical results for selected sediment types. $\mathrm{SCM}=$ sands/clays/marls.

3. Lake Monroe A.M.S radiocarbon dates for all cores. $\ddagger$ indicates conventional ${ }^{14} \mathrm{C}$ age exceeding $20,000 \mathrm{yrs}$. BP which are unable to be calibrated to calendar years B.P.

4. Lake Monroe stable isotope statistics for selected six cores (LM-06, LM-28, LM-31, LM-32, LM-45, LM-50). Number of samples = 111 .

5. Lake Monroe $\delta^{13} \mathrm{C}$ and $\delta^{15} \mathrm{~N}$ statistical results for surface sediments $(<3 \mathrm{~cm})$ of all cores. Number of samples $=20$. 


\section{LIST OF FIGURES}

FIGURE

1. Depiction of possible external and internal forcings subjected upon a lake (after Cohen, 2003)

2. Middle St. Johns River Basin (MSJRB) showing Lake Monroe and subbasin (gray). Major roadways, cities, and county lines are represented. Blue arrows indicate flow direction of St. Johns River, which flows east to west through Lake Harney and Lake Monroe (modified from www.sjrwmd.com).....10

3. Historical precipitation record for the city of Sanford, FL, 1931-2004. Station 087982 , Lat. $28^{\circ} 48^{\prime} \mathrm{N}$, Long. $81^{\circ} 16^{\prime} \mathrm{W}$. Precipitation data taken from the NOAA National Climatic Data Center.

4. Florida's central physiographic region depicting the numerous coast parallel ridge and swale features. The St. Johns River is thought to have become entrained in the Eastern Valley. Approximate location of river is marked dashed blue line. Approximate location of Lake Monroe, for reference, is marked by red star (after Miller, 1998)....

5. Lake Monroe site and sample location map with SJRWMD random sampling grid.

6. Sediment and water depth survey measurement schematic (Anderson et al.,

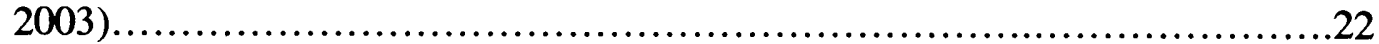

7. Lake Monroe sediment core location map. Sediment was recovered at 20 sites. Yellow sites indicate cores which were later dated.

8. Sediment removal system. Hydraulic jack raises measured wooden dowels and rubber plunger through core barrel, pushing sediment up and out of the

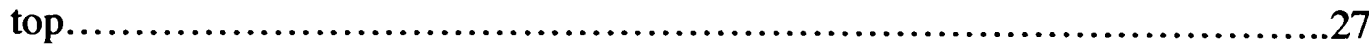

9. Three major sediment types identified during lake sediment survey: a) dark brown gyttja, b) light brown gyttja, c) SCM, and d) fibric peat...................36

10. Lake Monroe shaded bathymetric map with $50 \mathrm{~cm}$ contour interval. Location of greatest measurement of water depth is marked with an $x \ldots \ldots \ldots \ldots . . .38$

11. Lake Monroe floc thickness map with $3 \mathrm{~cm}$ contour interval. Location of greatest recorded measurement is marked with an $\mathbf{x}$ 
12. Lake Monroe sediment thickness map with $50 \mathrm{~cm}$ contour interval.

Location of greatest recorded measurement is marked with an $\mathrm{x}$

13. Lake Monroe generalized stratigraphy. Twenty (20) cores were removed on October 23-26, 2003 and visually described during upwards extrusion and sub sampling.

14. TIC, TOC, $\% \mathrm{~N}, \mathrm{C} / \mathrm{N}, \delta^{13} \mathrm{C}, \delta^{15} \mathrm{~N}$ plotted with depth, radiometric age, and lithology (LM-06, LM-28.)

15. TIC, TOC, $\% \mathrm{~N}, \mathrm{C} / \mathrm{N}, \delta^{13} \mathrm{C}, \delta^{15} \mathrm{~N}$ plotted with depth, radiometric age, and lithology (LM-31, LM-32).

16. TIC, TOC, $\% \mathrm{~N}, \mathrm{C} / \mathrm{N}, \delta^{13} \mathrm{C}, \delta^{15} \mathrm{~N}$ plotted with depth, radiometric age, and lithology (LM-45, LM-50).

17. Lake Monroe total ${ }^{210} \mathrm{~Pb}$ activity for selected six cores. Dashed line represents supported activity....

18. ${ }^{210} \mathrm{~Pb}$ calculated sediment accumulation rates according to $\mathrm{cf}: \mathrm{cs}$ model (LM- 28, LM-31, LM-32, LM-50).

19. TC and TN accumulation rates (LM-28, LM-31, LM-32, LM-50).

20. Total ${ }^{137}$ Cs activity (LM-28, LM-31, LM-32).

21. Overlay of six Holocene sea level curves for the Atlantic coast of the U.S. (after Scholl and Stuiver, 1967).

22. $\delta^{15} \mathrm{~N}$ vs. $\delta^{13} \mathrm{C}$. Values are distinct for sediment type. Blue $=$ gyttja. Red $=$ peat.

23. Cross plot of $\mathrm{C} / \mathrm{N}$ vs. $\delta^{13} \mathrm{C}$ depicting the evolution of biomass within Lake Monroe. Lake Monroe values plotted against Meyers plot (after Meyers, 2001). Values plotting in boxes represent predominate OM source. .68

24. TP values plotted with depth. Radiometric dates and lithology shown for reference. Phosphorus data from Anderson et al. (2005)...

25. $\mathrm{N} / \mathrm{P}$ and $\mathrm{C} / \mathrm{P}$ ratios plotted vs. $\delta^{13} \mathrm{C}$ and $\delta^{15} \mathrm{~N}$. Low $\mathrm{P}$-values, as indicated by high N/P and C/P values, show most depleted $\delta^{15} \mathrm{~N}$. Data suggests $\mathrm{P}$ controls production and subsequent isotope ratios within Lake Monroe sediments. High $\delta^{15} \mathrm{~N}$ corresponds with low $\mathrm{C} / \mathrm{P}$ and $\mathrm{N} / \mathrm{P}$ (high $\mathrm{P}$ concentration). 


\section{INTRODUCTION}

Lacustrine sediments and their organic matter (OM) fraction, by analyses of carbon and nitrogen isotopes and elemental composition (\%TOC, \% TIC, \%N, C/N) records, may be used as indicators of historic limnological change in geolimnological studies (Lehmann et al., 2004; McKenzie, 1985; Meyers, 1997). Subaqueous sediments contain information from which the histories of past climatic and environmental conditions may be reconstructed (Meyers, 2003). Paleolimnology, the interpretation of past conditions and processes in lake basins, is a multidisciplinary science nearly two centuries old (Last and Smol, 2001). Geologists in particular use their discipline to define paleolimnology emphasizing the sedimentological or geomorphic information useful for understanding the physical history of a lake (Cohen, 2003).

An important application of paleolimnology has scientists addressing acute and rapidly changing problems associated with human activity (Cohen, 2003). Paleolimnological records using multi-proxy methods are used to infer historic trophic states within lakes (Brenner et al., 1999b), including those possibly artificially precipitated by human activity in the basin. This information is most sought after by lake scientists concerned with both the natural evolution and the human impacts on lakes, and is of unprecedented value for understanding the current and future state of lake systems (Jinglu et al., 2004).

The recognition and timing of perturbations in lake primary productivity, shifts in trophic states, nutrient abundances, and sedimentation rates, are all important to the paleolimnological record. As their basis, paleolimnological investigations can establish baseline conditions within a particular basin, allowing for an improved understanding of the environmental changes and causes of geochemical variations in lake systems.

Unfortunately, long-term limnological data is lacking for Florida lakes (Brenner et al., 1999b). In the state of Florida alone, there are some 8000 bodies of fresh water 
(Brenner et al., 1999a), occupying approximately $8 \%$ of the total surface area (Ali et al., 1988), and as a result Florida may be considered to possess one of the richest freshwater resources in the world. Since the turn of the century many Florida watersheds have been subjected to increased anthropogenic stress, including, but not limited to: phosphate mining, citrus agriculture, road and railroad construction, residential and commercial development, ranching, row crop production, and hydrologic modifications (Brenner et al. 1999). Disturbances such as these enhance eutrophication and bring about the negative changes observed in so many of Florida's lakes (Ali et al., 1988).

Since development began in the Lake Monroe watershed, the lake has undergone significant changes, mostly in productivity. This condition is a common consequence seen in lakes throughout the world, which are subject to artificial nutrient loading as a result of human activities in the region, also referred to as cultural eutrophication. Cultural eutrophication denotes the effects brought about by increased inputs of nutrients to lakes, with the increase being a function of human activity in the catchment basin (Burgis and Morris, 1987; Cole, 1994).

Ultimately, the biological, chemical, and geological characteristics of a lake basin are related to age, climate, local geology, and lake morphology (Figure 1). But, additional factors, such as local land use and quality of inflow water may have a significant effect (Phelps and German, 1996). Reducing a problem, such as eutrophication, to a particular time, event, or source may be impossible, but an effort may be made to quantify the circumstances that forced the lake into such a state.

Lake Monroe is currently classified as hypereutrophic by the St. Johns River Water Management District (SJRWMD), while the condition of the lake prior to watershed development remains undocumented. A hypereutrophic system is characterized by low 


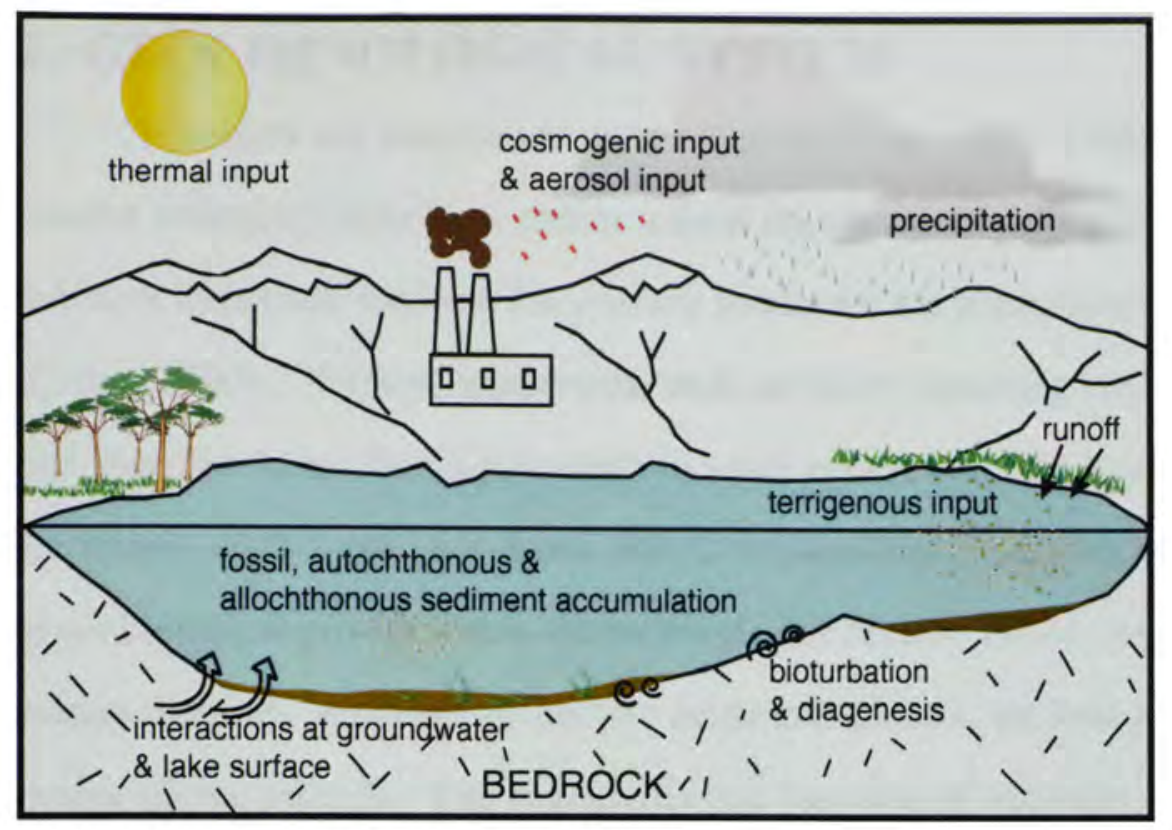

FIGURE 1 Depiction of possible external and internal forcings subjected upon a lake (after Cohen, 2003).

dissolved oxygen (DO), high nutrient loading, and abundant phytoplankton production. Conditions such as these are consistent with the lake's shallow morphometry, organic rich sediments, locally phosphorous enriched soils, and urban and agricultural runoff. The main purpose of this paleolimnological study is to determine if sediment nutrient characteristics within Lake Monroe have changed significantly over the last century. A multi-proxy and multi-disciplinary approach is used to compose a paleolimnological history of the lake to ultimately answer the question as to how Lake Monroe has evolved into a hypereutrophic waterbody.

Studying changes in lake sediments is a common, effective, and necessary approach when quantifying the impact of humans on an ecosystem (Brenner et al., 1999a; Jinglu et al., 2004; Meyers, 2003). The results of this study will contribute fundamental and much needed information to the paleolimnological record of Florida. 


\section{GEOLIMNOLOGICAL SYSTEM}

Nutrients are essential to primary production within a lake ecosystem, as their relative abundance may limit and/or control the growth of cells and populations. Two of the most important nutrients for primary producers are phosphorus $(\mathrm{P})$ and nitrogen $(\mathrm{N})$ (Cohen, 2003). Nutrient compounds, such as those containing combinations of nitrogen and phosphorus, are limiting nutrients in a lake ecosystem. The oxidized form of $\mathrm{N}$ and $\mathrm{P}$ are nitrates $\left(\mathrm{NO}_{3}{ }^{-}\right)$and phosphates $\left(\mathrm{PO}_{4}^{3-}\right)$ respectively. These nutrient compounds serve to aid biological growth within lakes (Burgis and Morris, 1987). As an example, both are essential for the synthesis of nucleic acids and protein, as well as for energy transfer during photosynthesis. The availability and function of nutrients can vary, both within and without of the lake, yet their roles in cell processes and primary productivity remain consistent.

Long-term increases in the concentration of phosphorus in sediments have occurred in many rivers and lakes in recent decades, not only in Florida but throughout the world (Jennings et al., 2003). Phosphorus, not being one of the most abundant elements on Earth ( $0.1 \%$ of earth's crust) is still essential to all life, and may be considered an ultimate regulator of productivity because of its demand and relative scarcity (Cohen, 2003). Phosphorus comes from mainly terrigenous sources, as continental weathering of phosphate bearing igneous and metamorphic rocks releases apatite minerals. These minerals are then transferred to water bodies in particulate form bound in organic material, which can be deposited as sediment or dissolved phosphate, allowing utilization and production of organic matter by primary producers (Sondergaard et al., 2001). Phosphorus can be taken up rapidly and concentrated by living organisms (Cole, 1994), and serves an important role in the metabolism of an organism.

Another important and considerable source of phosphorus, which must be accounted for when studying lakes in an economically developing area, are phosphates 
derived from agricultural fertilizers and urban and agricultural sewage (Cohen, 2003). These phospates may be delivered to a lake at elevated levels via groundwater discharge or overland runoff. Nutrients such as phosphorus, have long been recognized as vital to the overall water quality and health of a lake, as their presence in excess may have severe consequences. If P loading, from either natural or unnatural sources is excessive, a lake may switch from macrophyte dominance to a phytoplankton (algae, cyanobacteria) dominated system (Kenney et al., 2002). This proposed switch may lead to a eutrophic state marked by turbid water quality, toxic algal species, low dissolved oxygen (DO), fish kills, and submerged macrophyte losses (Sondergaard et al., 2001). These conditions have been and are present at Lake Monroe (Ali et al., 1988; Frouz et al., 2004).

Another essential element, nitrogen, is far more naturally abundant and available for biological fixation, in the form of atmospheric $\mathrm{N}_{2}$, than is phosphorus in the biosphere. Nitrogen is an essential component of molecules in all living material, as all organic proteins, nucleic and amino acids contain nitrogen (Brenchley and Harper, 1998; Burgis and Morris, 1987). If bacteria present in the lake are able to break down essential nutrients into forms readily available for organic metabolism, than an increase in production will be eminent, considering no other limiting factors. Nutrient levels in a lake play a large role in the overall synthesis of organic material. Since nutrients, such as nitrates (and phosphates), are the inorganic and organic substances that are essential for the growth of plants, their availability holds a dominant control on productivity (Brenchley and Harper, 1998).

In most cases, an increase of nutrients to a basin through time results in an increase of productivity, a measure of the amount of carbon fixed by primary producers per unit area per time. This increase in production is synonymous with an increase of photosynthesis by aquatic plants. Plants assimilate nutrients from sediment porewater and/or the water column, take in carbon, in the form of $\mathrm{CO}_{2}$ gas (aqueous or 
atmospheric), and "fix" it into solid organic plant material (Burgis and Morris 1987).

Through time, as these nutrients are consumed and assimilated by algal cells and macrophytes, eventual death or aging of the tissue (Sonzogni et al., 1982) will result in the accumulation of OM upon the lake bottom (Ali et al., 1988).

\subsection{Productivity and Source Indicators}

The importance of OM composition in paleolimnological geochemical analyses lies within the ability to identify its sources. As "geochemical fossils", the OM portion of lake sediments can be used to reconstruct a whole variety of human and natural induced changes in basins (Meyers, 2003). Changes in source material can be attributed to a whole suite of climatic, environmental, anthropogenic, and productivity shifts, all of which can potentially be determined geochemically. A convenient record of source materials is provided within the elemental and isotopic compositions of sedimented OM. Although $\mathrm{OM}$ is subject to diagenesis upon deposition, its bulk parameters still remain reliable indicators of sources vital to understanding the past and present lake ecosystem (Meyers and Lallier-Verges, 1999).

Through the recognition of isotopic variations within the organic sediment record, isotope studies are very effective at determining relevant factors related to the paleoproductivity of a lake. (Peterson and Fry, 1987). The majority $(>95 \%)$ of both terrestrial and lacustrine plants photosynthetically fix carbon into organic matter using the $\mathrm{C}_{3}$ pathway. Through this process carbon fixation and photosynthesis occur in the mesophyll (surface) cells of the plant following the standard Calvin Cycle. This is a unique physiological function of select plants, which preferentially take up ${ }^{12} \mathrm{C}$ in the form of ${ }^{12} \mathrm{CO}_{2}$ (Meyers and Lallier-Verges, 1999), thus discriminating against ${ }^{13} \mathrm{CO}_{2}$ and producing a significantly different corresponding isotope ratio (Schleser, 1985) in the plant tissue. This isotope fractionation process, which is biologically mediated, is known 
as the kinetic isotope effect, and it generally records synthesized OM depleted in ${ }^{13} \mathrm{C}$ (Hoefs, 1997).

Organism's metabolic pathways are under non-equilibrium conditions, suggesting biological fractionations which are associated with incomplete or unidirectional processes (Hoefs, 1997). Stable carbon-isotope ratios of TOC are frequently used to distinguish among sedimented terrestrial and aquatic plant sources, which differ in methods of $\mathrm{CO}_{2}$ concentration, photosynthetic fixation pathways and subsequently in the net fractionation against ${ }^{13} \mathrm{C}$ (Filley et al., 2001).

Fractionation is the process that causes stable isotopes to vary in abundance, and refers to the partitioning of an isotope into two or more parts, each which will have different ratios of heavy to light isotopes in the residual. The general rule concerning isotope fractionation is that the heavy isotope concentrates in the compound in which the element is bound most strongly. The cause for this mode of isotope concentration is the relatively inefficient carbon fixation process that occurs between external and cellular $\mathrm{CO}_{2}$ in both aquatic and terrestrial plants, which is responsible for observed large ${ }^{13} \mathrm{C}$ depletions (Hoefs, 1997). During photosynthesis, which is the carbon fractionation process in plants, the light isotope $\left({ }^{12} \mathrm{C}\right)$ is concentrated (enriched) in the living material while the heavier isotope is left remaining in the inorganic pool. Consequently, $C_{3}$ plants can have observed fractionations as high as $-29 \%$. Stable isotope values (\%o) are reported in standard delta $(\delta)$ notation relative to the international standards of atmospheric nitrogen (AIR) and the Vienna Peedee Belemnite (VPDB) using the formula:

$$
\delta^{13} \mathrm{C}_{\mathrm{OM}} \text { or } \delta^{15} \mathrm{~N}_{\mathrm{OM}}=\left(R_{\text {sample }}-R_{\text {standard }}\right) / R_{\text {standard }} \times 1000
$$


Periods of high nutrient (N, P) conditions allows organisms to isotopically discriminate, leading to isotopically depleted organics. However, during periods of increased levels of productivity, ${ }^{12} \mathrm{C}$ becomes relatively depleted from the dissolved inorganic carbon (DIC) pool forcing plants to uptake the heavier isotope, resulting in OM enriched in ${ }^{13} \mathrm{C}$ (Brenner et al., 1999; McFadden et al., 2004; Schelske and Hodell, 1995). The relationship between these processes is simple. As productivity within the lake increases, isotopic discrimination will decrease, forcing cells to rely on the heavier isotopes for carbon and nitrogen fixation leading to isotopically enriched organics. Also, although rare, rapid rates of productivity may deplete the water column of free aqueous $\mathrm{CO}_{2}$ forcing plants to rely on $\mathrm{HCO}_{3}^{-}$(bicarbonate). $\mathrm{HCO}_{3}^{-}$is $8 \%$ heavier than $\mathrm{CO}_{2}$ (aq) thus producing OM that is consequently ${ }^{13} \mathrm{C}$-enriched (Brenner et al., 1999). These basic assumptions regarding productivity and isotope abundances are made without consideration of numerous other limiting factors which occur in the biological world. Factors such as, light, $\mathrm{pH}$, nutrient source, DIN and DIC availibility, all have some control over the detected isotope value. 


\section{SETTING}

Lake Monroe is a relatively large yet shallow (Table 1) open-basin lake situated along the St. Johns River in east-central Florida (Figure 2). The lake lies along the northern fringe $\left(28^{\circ} 50^{\prime} \mathrm{N}\right.$ latitude, $81^{\circ} 15^{\prime} \mathrm{W}$ longitude) of the City of Sanford, on the county line, separating northwestern Seminole and southeastern Volusia Counties, FL. This location places Lake Monroe within the Middle St. Johns River watershed basin (MSJRB), as well as Florida's central lake district. The MSJRB encompasses the watersheds of five major sources to the St. Johns River: the Wekiva and Econlockhatchee rivers, Howell Creek through Lake Jesup, Deep Creek through Lake Harney and various other flows of water into Lake Monroe (Figure 2), and drains an area $3,120 \mathrm{~km}^{2}$ in size. The MJSRB is one of three watersheds delineated by the St. Johns River Water Management District (SJRWMD), the governing board for the St. Johns River, a 310 mile, north-flowing Atlantic bound river, that stretches from the wetlands of Ft. Drum Marsh to Jacksonville, FL, USA. The SJRWMD is one of five water management districts in Florida, and their jurisdiction encompasses 12,300 square miles in the northeast and east-central part of the state, or $21 \%$ of the total area of Florida. SJRWMD includes all or part of 18 counties with nearly four million people, and $25 \%$ of the state's population.

TABLE 1 Lake Monroe physical dimensions.

Water depth measurements recorded in June, 2003.

\begin{tabular}{|c|c|c|}
\hline \multicolumn{3}{|c|}{ Morphometric Data } \\
\hline Surface area & $=$ & $36 \mathrm{~km}^{2}$ \\
\hline Max width & $=$ & $5.8 \mathrm{~km}$ \\
\hline Max length & $=$ & $9.3 \mathrm{~km}$ \\
\hline Depth & $\begin{array}{l}\min = \\
\max = \\
\operatorname{mean}=\end{array}$ & $\begin{array}{c}55 \mathrm{~cm} \\
275 \mathrm{~cm} \\
214 \mathrm{~cm}\end{array}$ \\
\hline
\end{tabular}




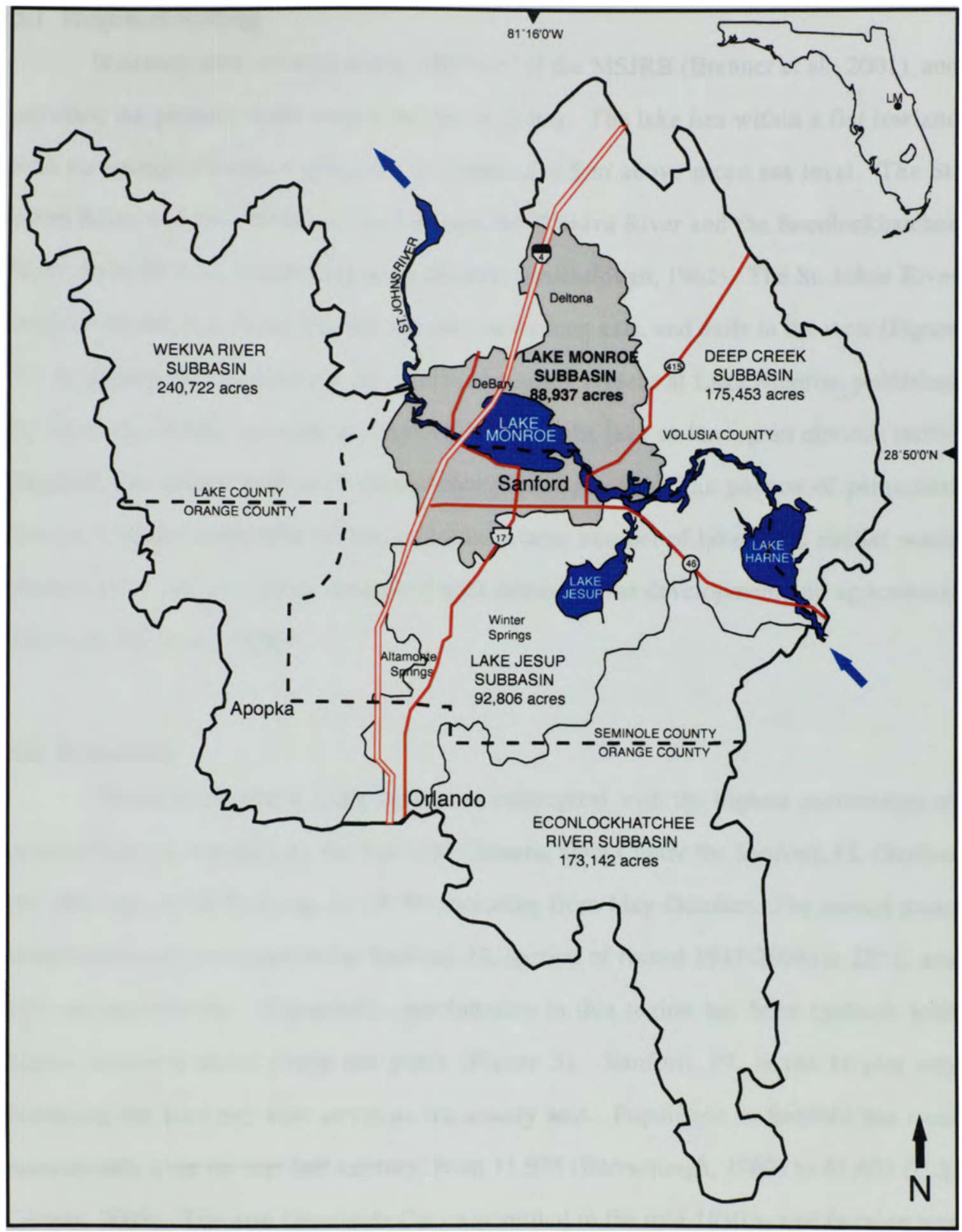

FIGURE 2 Middle St. Johns River Basin (MSJRB) showing Lake Monroe and subbasin (gray). Major roadways, cities, and county lines are represented. Blue arrows indicate flow direction of St. Johns River, which flows east to west through Lake Harney and Lake Monroe (modified from www.sjrwmd.com). 


\subsection{Regional Setting}

Wetlands once covered nearly $1800 \mathrm{~km}^{2}$ of the MSJRB (Brenner et al., 2001), and provided the primary water source for the St. Johns. The lake lies within a flat lowland with an average elevation along the St. Johns of $1.5 \mathrm{~m}$ above mean sea level. The St. Johns River and its tributaries; Lake Jessup, the Wekiva River and the Econlockhatchee River drain the land surrounding Lake Monroe (Barraclough, 1962). The St. Johns River enters from the east, flows through the lake on its long axis, and exits in the west (Figure 2). A pioneering report on the lake water chemistry present at Lake Monroe, published by Ali et al. (1988), reported amongst other things the lake as having an obvious turbid physical appearance with no floating macrophytes present. The portion of peninsular Florida in which Lake Monroe lies, contains a large number of lakes with similar water quality issues, as those often associated with intense urban development and agricultural activities (Ali et al., 1988).

\subsection{Historical}

The local climate at Lake Monroe is subtropical with the highest occurrences of precipitation, as reported by the National Climatic Data Center for Sanford, FL (Station 087982, Lat. $28^{\circ} 48^{\prime} \mathrm{N}$, Long. $81^{\circ} 16^{\prime} \mathrm{W}$ ), occuring from May-October. The annual mean temperature and precipitation for Sanford, FL (period of record 1931-2004) is $22^{\circ} \mathrm{C}$ and $133 \mathrm{~cm}$ respectively. Historically, precipitation in this region has been cyclical, with highs occurring about every ten years (Figure 3). Sanford, FL is the largest city bordering the lake and also serves as the county seat. Population in Sanford has risen considerably over the last half-century, from 11,935 (Barraclough, 1962) to 43,455 (U.S. Census, 2002). The area (Seminole Co.) was settled in the mid 1830's, and farming was not long to follow as the first orange groves were planted in 1840 (Barraclough, 1962). 


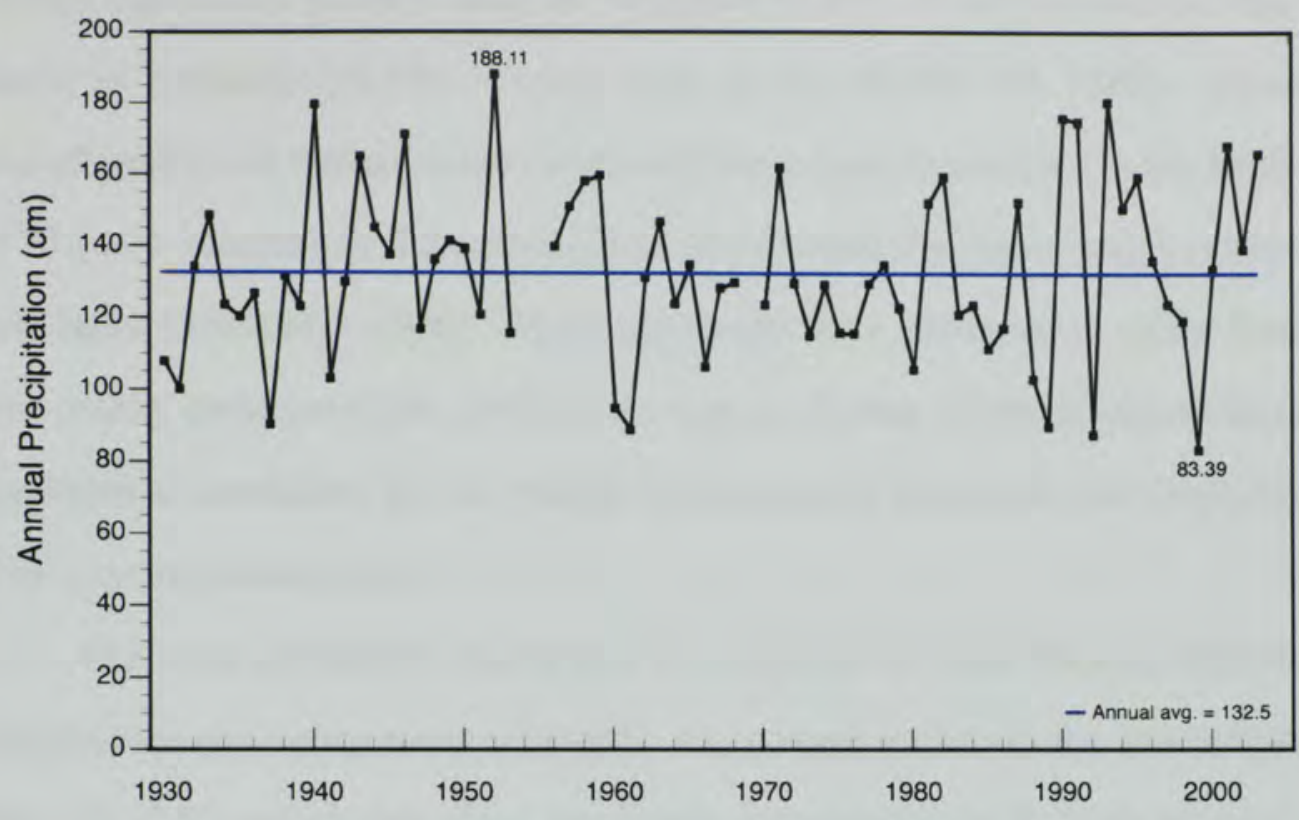

FIGURE 3 Historical precipitation record for the city of Sanford, FL, 1931-2004. Station 087982, Lat. $28^{\circ} 48^{\prime} \mathrm{N}$, Long. $81^{\circ} 16^{\prime} \mathrm{W}$. Precipitation data taken from the NOAA National Climatic Data Center.

Beginning around 1900, the local wetlands, which possessed nitrogen-rich soils, were drained and exploited for ranching, citrus production, row crops (Brenner et al., 2001 ) and private development (EPA, 1992). By the 1950's, Seminole County alone had over 16,000 acres of agricultural land, and as a result, the floodplain was reduced in size to $725 \mathrm{~km}^{2}$. In the mid-1960's, under drought conditions, the floodplain was a meager $260 \mathrm{~km}^{2}$. Additional drainage of the lands came as a result of government intervention. In 1954, Congress authorized flood control works to begin in the Upper St. Johns River Watershed Basin (USJRWB), the watershed basin immediatley upstream from Lake Monroe. The U.S. Army Corps of Engineers began construction of major drainage canals in 1966, used to divert water from the St. Johns Rivers marshes east to the Indian River Lagoon. By 1974, the project was deemed environmentally unacceptable, and put to a 
halt (EPA, 1992). By 1980, nearly $80 \%$ of the USJRWB had been converted to pasture (70.6\%), agriculture $(5.0 \%)$, urban development $(3.4 \%)$, or silviculture $(0.1 \%)$, with the balance in wetlands (18.5\%) or open water (2.3\%) (SJRWMD, 1980). Thousands of miles of canals and ditches, levees and roads have been constructed in the basin over the last 75 years resulting in a significant loss of historical floodplain marsh in the St. Johns River basin (SJRWMD, 1980). These alterations have attributed to major flooding and water quality problems (EPA, 1992) in the region. In fact, 19 waterways within the basin were listed as candidates for the Florida Department of Environmental Protection's 1998 list of impaired water bodies.

The town of Sanford, the largest city adjacent to Lake Monroe, was founded in 1870 , but was not incorporated until 1877 . Main roads leading to the area include what is today US 17/92, which runs along the southwestern boundary of Lake Monroe, entering Sanford near the historic center. Construction of these roads started in 1915 and were finished in 1916 (Anderson et al., 2005). Before 1946, this route was known as FL 3, and included a bridge over the outlet of the lake (as noted on a highway map of the State of Florida, circa 1927). Also, interstate I-4 opened in Sanford in 1969, which included a bridge over the western outlet of the lake (Anderson et al., 2005).

\subsection{Geological}

The only geologic units exposed near the lake are of Recent $(<10,00 \mathrm{yrs})$ age, and consist of fine to coarse quartz sands, ranging in thickness from 3 to $25 \mathrm{~m}$. These deposits are interbedded with layers of clay, and in the proximity of the St. Johns, shell fragments. They rest unconformably upon Pliocene or late Miocene (Figure A-1) age deposits of blue clay, and shell beds termed the Nashua marl, which Brooks (1966) describes as an old estuarine fill. In turn these units are underlain by the Hawthorne Formation, which contains interbedded calcareous clay, limestone and phosphorite- 
bearing ( $>15 \% \quad \mathrm{P}_{2} \mathrm{O}_{5}$ by weight) sediments of middle Miocene Age (Compton, 1997). The Hawthorne is present throughout the Upper/Middle St. Johns River watershed except along the river itself where it has been uplifted (Sanford high) and eroded. The Hawthorne rests unconformably upon the Ocala Group (foraminiferal marine limestone), and where absent, upon the Avon Park Limestone (partially dolomitized chalky limestone) of middle Eocene (Wyrick, 1960).

The evolution and geomorphology of Florida's fresh water lakes and rivers varies depending on the region and more importantly the geology. Landforms, either positive or negative, are the product of geologic structure, rock type, and rate of erosion or aggradation (Schmidt, 1997). Modern Florida landforms show the dominant effect of marine forces in shaping the land surface, as millions of years of sea-level fluctuations have lead to subsequent erosional and depositional events, leaving no doubt that the regional landscape is geologically young and coastal in origin (Miller, 1998; Scott, 1997).

The history of the Florida Platform, on which the current State rests, is complicated, as it is the result of over 500 million years of differing geologic environments, from tectonic rifting during the Mesozoic to carbonate sedimentation throughout the Cenozoic (Randazzo, 1997). Hence, the hydrogeology and hydrology of this area of Florida, is a direct result of the underlying geology. Although the present or exposed surface, is only a minor reflection of the events that preceded, the modern surface may still provide evidence for the formation and location of these surface features. Theories published (Barraclough, 1962; Lane, 1994; Scott, 1997) concerning the evolution and shape of Florida's negative and positive surface features aid with deciphering the geologic history. An abundance of relict features (beach ridges, valleys, karst) are present throughout the state, making interesting ideas over their origins abound. These physical features of the land surface of central Florida have been used to define distinct physiographic regions (Figure 4) within the state (Schiffer, 1998). 


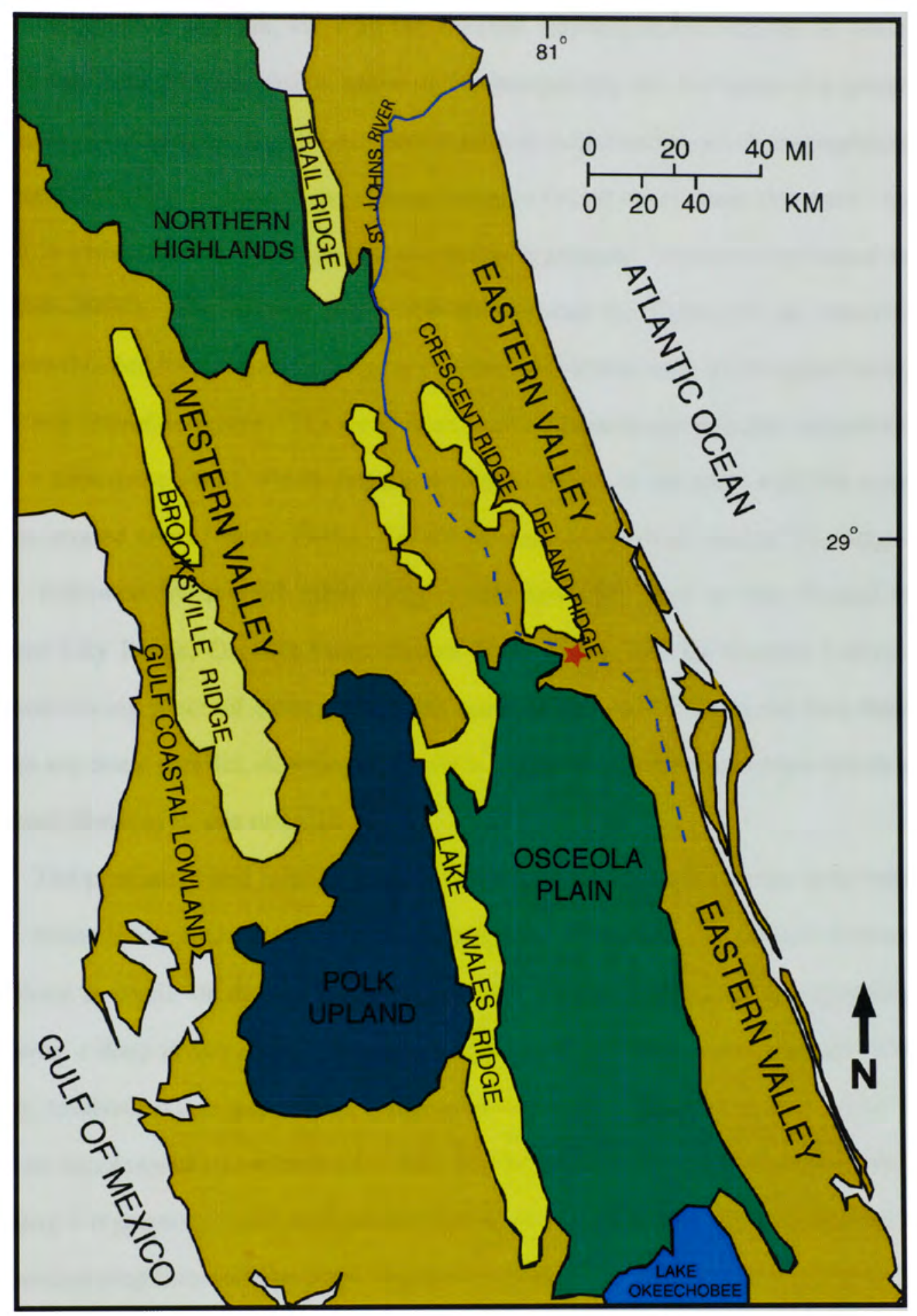

FIGURE 4 Florida's central physiographic region depicting the numerous coast parallel ridge and swale features. The St. Johns River is thought to have become entrained in the Eastern Valley. Approximate location of river is marked dashed blue line. Approximate location of Lake Monroe, for reference, is marked by red star (after, Miller, 1998). 
Physiographic regions, such as the Central Physiographic Region in which the MSJRB and Lake Monroe reside, are used for interpreting the evolution of a geographic area. Ridge (topographic high) (i.e. Atlantic coastal ridge) and swale (topographic low) (i.e. Eastern Valley) are common coastal features found throughout the state. Central Florida is characterized by these discontinuous highlands, separated by broad valleys (Schiffer, 1998). Fluctuating sea levels throughout the Cenozoic are theorized to beresponsible for forming and exposing submarine features such as elongate bars, spits, shoals, and shoreline scarps. The most prominent of these features is the Atlantic Coastal Ridge, a submarine shoal, which extends the entire length of the state, with the exception of some eroded areas (Scott, 1997). On the leeward (westward) side of this ridge lies a valley, followed by several other ridge swale systems, such as the Deland Ridge, Crescent City Ridge, Osceola Plain, Mount Dora Ridge, and the Central Valley. The most convincing piece of evidence for the cause of this landscape is the fact that these features are coast parallel, denoting multiple transgressions and regressions which would leave such features in this orientation.

The prominent and relative feature of the central Florida landscape with respect to the St. Johns River is the Eastern Valley (Figure 4). This negative feature is thought to have been a swale or depression between two ridges, formed by a regressing sea. Following a drop in sea level, these areas adjacent to or behind beach ridges or barrier islands, retained water and became estuarine lagoons. This ponding of water would cause an accelerated movement of water downwards due to the declining water table following a regressive event, and possibly facilitate lake formation due to the dissolution of the underlying carbonate bedrock (Schiffer, 1998). 


\subsection{Limnological}

One, or several different processes, may form lakes and consequently rivers in the region of Florida in which Lake Monroe resides. The most common process is the dissolution of carbonate material by water (karst). Since the Florida Platform has a low relief, highly permeable soil and rock, and experiences a high annual rainfall, this process seems most plausible (Miller, 1997). Surface water may percolate down and dissolve the rock, or in some uplifted areas where rock or sediments are aerially exposed, facilitate accelerated erosion. Areas of central Florida and along the St. Johns River especially, where there are a cluster of relatively round-shaped lakes, are believed to be of karst origin.

Other theories (White, 1970) suggest that depressions (swales) in the ancient sea floor may have retained water or captured freshwater upon a drop in sea level, which may help facilitate dissolution and lengthen a lagoon into a series of lakes possibly coalescing to form a river. Yet, another hypothesized method may have been the enlargement of naturally attenuated lakes by riverine or fluvial processes. Flow through a solution basin would further dissolve material and could enlarge small bodies of waters into larger ones. Most likely, fluvial processes, when combined with other lake formation processes, could enlarge or change the form or path of a lake (Miller, 1997). Lakes that are thought to have formed in this manner will exhibit a particular geometry. They will be roughly round in shape, with an inlet and an outlet at approximately the same position on either side of the lake. These flow through lakes are described as being "threaded" by the river (White, 1970).

The origin of the St. Johns River may have been the result of several geological processes. Historically, the river is reported and assumed to be an ancient intracoastal Pamlico (late-Pleistocene) lagoon that was enclosed or captured by a barrier in the form of the Atlantic Coastal Ridge (White, 1970) in a similar method as to that described in the 
preceding section. Yet, a closer look at the valley, in which the river resides (Eastern Valley), reveals several beach ridges throughout much of the length and width of the valley, leading others to believe that the valley was not a large swale. These relict beach ridges are severely eroded yet still remain aerially recognized based on their influence upon the drainage pattern within the valley. This has led White (1970) to theorize the Eastern Valley as being a regressional or progradational beach ridge plain.

The St. Johns River also exhibits a pattern of widening as it proceeds northward. Widening may be attributed to a greater dissolution of relict beach ridges in that direction, which suggests that the course of the river was determined by the relative composition $\left(\% \mathrm{CO}_{3}\right)$ of the swales between relict beach ridges rather than a consequence to a relict lagoon. This dissolution could certainly be accelerated by the presence of Eocene age limestone at or near the surface in this region (Pirkle, 1971). Therefore, the principal process of formation seems to have been the dissolution of limestone (White, 1970). It may have been a standing body of water at one time, but reacted, and preferentially flowed northward, as a result of dissolution downgradient/stream and infilling along the floodplain, rather than just flowing in the lower plains of the valley.

Additional evidence for dissolution of relict beach ridges driving or capturing the flow of the St. Johns lies at the site of Lake Monroe, where a change in the direction of flow has caused some controversy over its origin (Figure 4). Barraclough (Barraclough, 1962) attributed the St. Johns jog westward at this location to the presence of a fault beneath the lake, as evidenced by a change of the surface elevations north of the lake. The surface is higher north of the lake, possibly suggesting an up-thrusted fault block. If this theory were accurate, the St. Johns would change its northerly course, and flow through the fault basin. This may be the case, yet White (1970) further suggests that the offset may have existed before the headwaters of the river were even formed. If solution had preferentially dissolved a predominately carbonate rich beach ridge at that location, 
than was subsequently flooded during a transgressional event, the depression would have stored water upon a decrease in sea level. It is during this low stand in sea level that it is believed the St. Johns Offset captured the marshy intracoastal lagoon east of its location. A subsequent rise, or rises, of sea level, which occurred throughout the Pleistocene, and as late as $130,000 \mathrm{yr}$ B.P. (Osmond et al., 1970), may have integrated this sequence of lagoons/estuaries into modern day lakes linked together by the St. Johns River. 


\section{MATERIAL AND METHODS}

A total of 81 cores were recovered from Lake Monroe over a period of 5 months. In June, 200360 cores were recovered for surficial sediment description and water depth measurements. This was followd by an additional 21 sediment cores recovered in October, 2003 for sediment subsampling and geochemical analyses. All sediments were analyzed in incremental $3 \mathrm{~cm}$ intervals for TC, TIC, TOC, and TN. Six cores (LM-06, LM-28, LM-31, LM-32, LM-45, LM-50) were analyzed for $\delta^{15} \mathrm{~N}, \delta^{13} \mathrm{C},{ }^{21}{ }^{10} \mathrm{~Pb},{ }^{137} \mathrm{Cs}$, and ${ }^{14} \mathrm{C}$, with the exception of core LM-50B, a replicate core of LM-50, which was analyzed at $1 \mathrm{~cm}$ intervals for dating purposes.

\subsection{Station Selection}

The sampling regime for this study was based upon 60 random pre-determined stations (Figure 5) assigned by the SJRWMD. The stations were chosen by the SJRWMD by overlaying an equal area grid upon the aerial extent of the lake, and choosing random points that fell within each grid space. Coordinates for the stations were taken from the equal area grid, and accompanied with a Wide Area Augmentation System (WAAS) Global Positioning System (GPS) to ensure proper site location when in the field.

\subsection{Spatial Sediment and Water Depth Survey}

On June 25-27, 2003, an initial survey of the sediment type and water depth at each station was carried out (Anderson et al., 2005). The collected data was necessary for determining which stations demonstrated favorable sediment and depth conditions for coring and retrieval of sediments to be used in future geochemical analyses. Data from Anderson et al. (2005) was used to generate several maps, using Geographical Information Systems (GIS) software (see section 4.3). 


\subsubsection{Water Depth}

The depth of the water column to consolidated sediments was measured by taking a sounding using a non-buoyant, 3/4" diameter, schedule 40, PVC pipe, to which a flat bottom \#12 rubber stopper was attached. The device was placed into water, and lowered by hand until resistance was encountered. Upon feeling resistance from the floc/consolidated sediment interface, the water depth was marked on the shaft, measured to the nearest centimeter (Figure 6), and recorded.

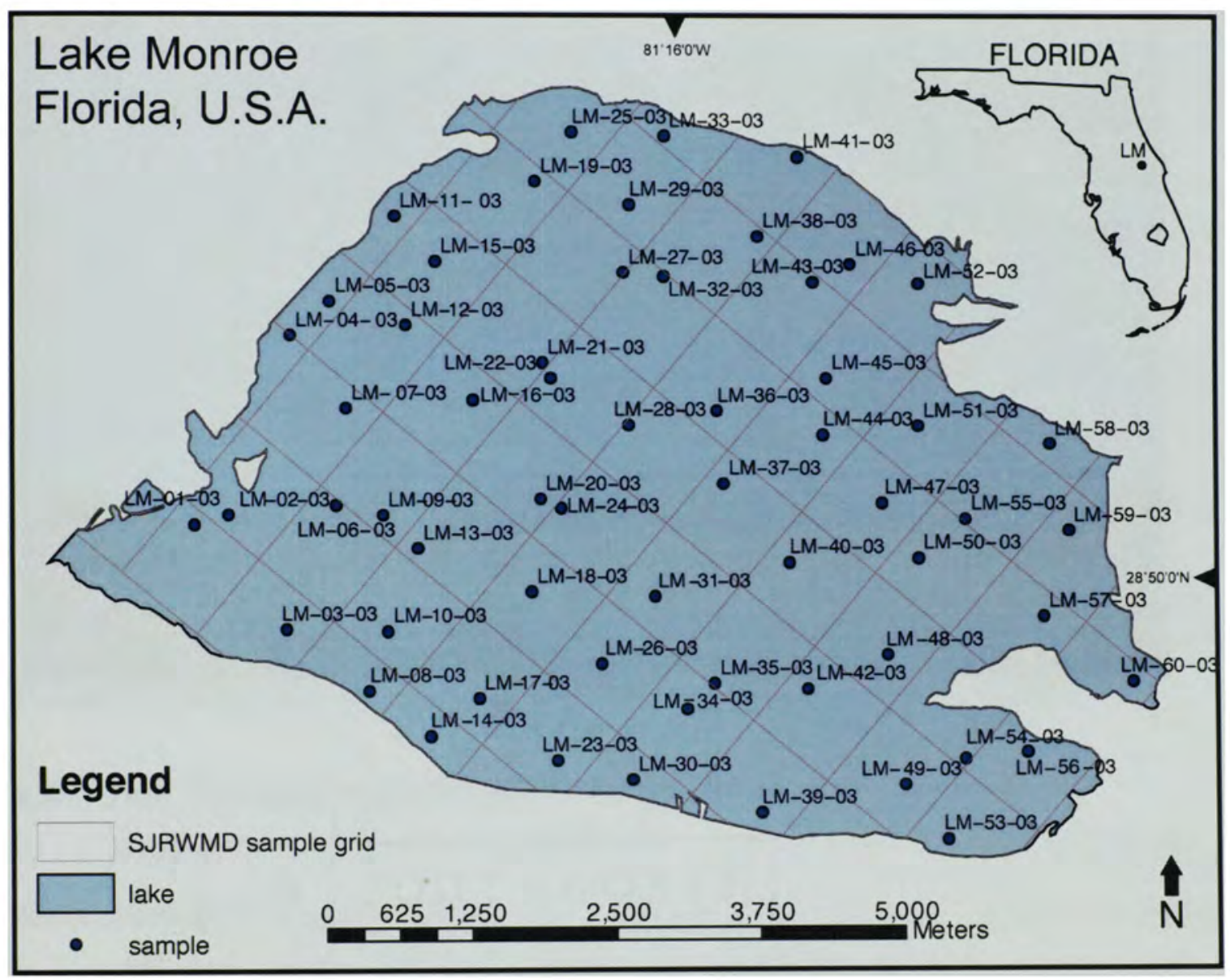

FIGURE 5 Lake Monroe site and sample location map with SJRWMD random sampling grid.

\subsubsection{Sediment Thickness}

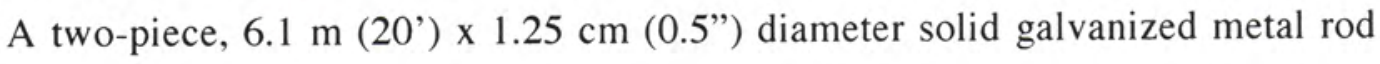
(commercially available lightning rod) was used to measure sediment depth. The rod was 
firmly inserted by hand into the sediment until refusal was met. The point at which the rod could travel no further was considered to be the bedrock surface. The sediment thickness measurement was the distance from the top of the bedrock to the sediment water interface. The rod was marked at the water surface and measured upon removal (Figure 6).

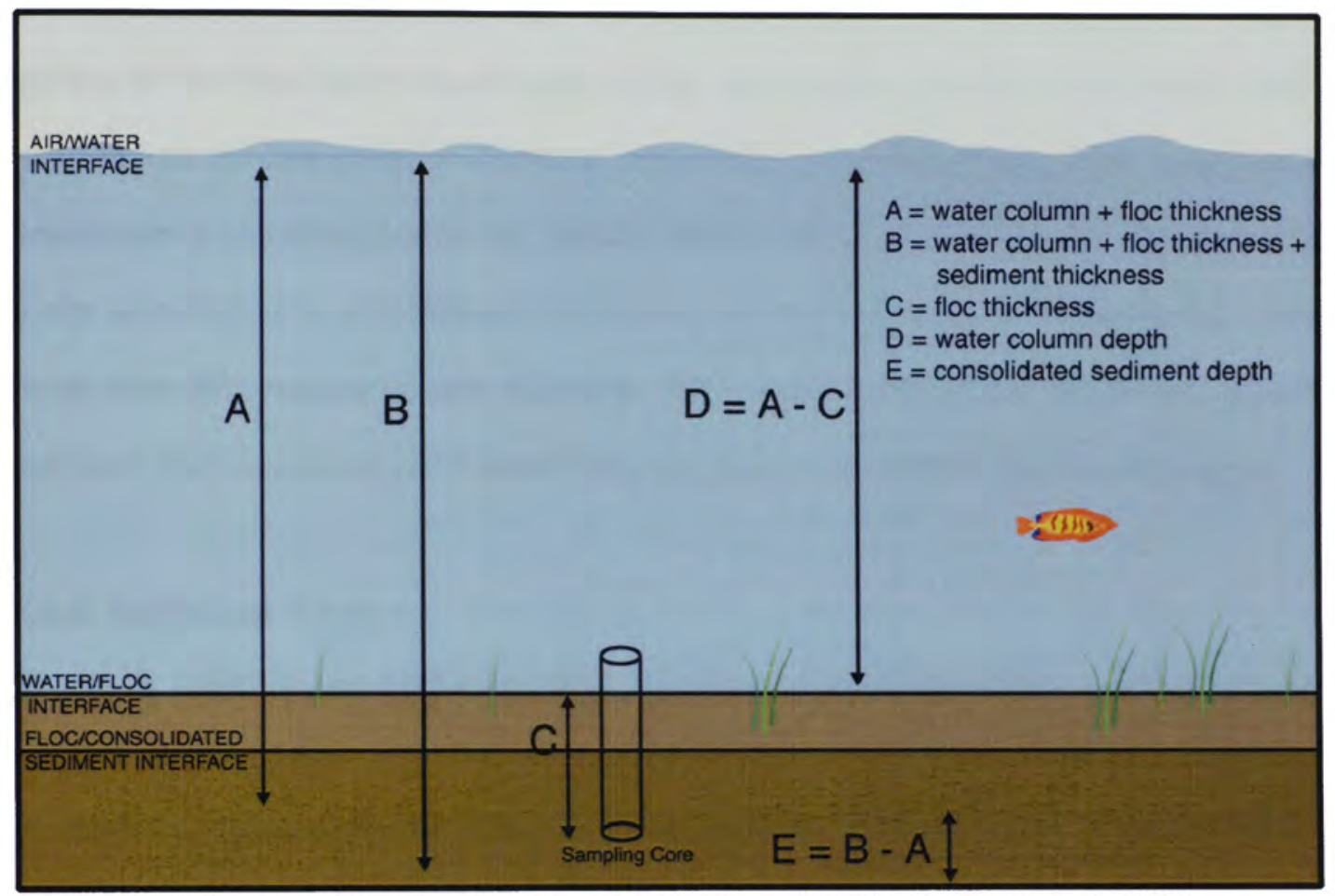

FIGURE 6 Sediment and water depth survey measurement schematic (Anderson et al., 2003).

\subsubsection{Floc Thickness and Sediment Collection}

Collection of sediments for descriptive analysis, were obtained by collecting intact short cores $(<30 \mathrm{~cm})$. Cores were collected using a specially constructed gravity corer with a $5.1 \mathrm{~cm}$ inside diameter (2") core tube made of clear plastic acrylic. Coring was done by firmly inserting the core tube into the sediment, closing a valve on the top to eliminate the downward hydrostatic pressure, and removing the core barrel and sediment intact. The core barrel was removed from the sediment and brought to the water surface where a \#12 rubber stopper was placed in the bottom to prevent loss of the core sample. 
The coring apparatus, attached to the top of the core barrel, was dismantled and the unconsolidated (floc) and consolidated sediment was extracted from the bottom up. A plunger was inserted into the bottom of the core and raised throughout the core barrel, thus forcing upwards and exposing the sediment out of the top. As the sediment was driven upwards, any lake water within the core barrel overlying the sediment/floc was allowed to flow off, leaving only sediment remaining in the core barrel. The upper surface of the floc layer was brought to the top of the core tube and a small ruler was inserted into the floc until resistance of consolidated sediments was felt beneath the layer. Resistance is considered to be the bottom of the floc layer, and the distance from the top of the core barrel to consolidated sediments to be the thickness of the layer. The floc depth was then measured and recorded. With only consolidated sediments remaining, extrusion was continued while measuring the depths of visually discrimnate layers.

\subsubsection{Sediment Type}

In addition to measurements of floc/sediment thickness and water depth, performed at 60 sites (see Figure 5), intact short cores were removed and sediment described. Extruding the sediment from the bottom-up allowed for visual discrimination of consolidated sediment layers, which were identified, described, and measured. This data was then used for creating a spatial sediment distribution map in GIS.

\subsection{GIS Analyses}

Maps (bathymetric, isopach) were created to aid in the decision-making process of where to core, yet the method of creating such maps, proved to be challenging. For data that is unevenly spaced and whose values vary spatially across an area-such as lake water depth, sediment thickness, and floc thickness, a Triangulated Irregular Network (TIN), may be used to create a surface. A TIN is built from a series of irregularly spaced 
points with values that describe the surface at that point (e.g., depth, thickness). A height can be calculated for any point on the surface by interpolating a value from the nodes of nearby triangles. From these points, a network of linked triangles is constructed. Adjacent triangles, sharing two nodes and an edge, connect to form the surface. Here the input TIN was specified based on which lake parameter was being analyzed, as well as the attribute, which in our case was elevation. The $\mathrm{Z}$ factor was left as default (1.00), and the cell size specified: Bathymetric $=10.00$ meters, Floc $=5.00$, Sediment $=5.00$. Furthermore, to smooth these raster grids and create a better surface to contour, the Neighborhood Statistics resample function was performed using Environmental Systems Resarch Institute (ESRI) ArcGIS 8.3 Spatial Analyst software. This focal function, computes an output raster where the value at each location is a function of the input cells in some specified neighborhood of the location. Bathymetric $=$ height/width 15 , grid 5.00, Floc $=$ height $/$ width 10 , grid 5.00, Sediment $=$ height $/$ width 21 , grid 20.00. This method proved to be an effective means of smoothing the raster grid surface in preparation for contouring. Following this re-sampling method, the resultant smoothed raster grid was contoured using the contour option in 3-D Analyst. The contour interval was specified (see figures) and the base contour was set to zero.

One manner of displaying and interpreting data spatially is through the use of GIS. GIS is a relatively new science, which is used across a wide array of disciplines. Earth scientists in particular have made great use of this burgeoning technology. Using ArcGIS 8.3, the large amount of collected data was interpreted and displayed in a spatial manner. Bathymetric, sediment thickness, and floc thickness maps were all created using ArcGIS 8.3, with measurements obtained in the field by Anderson, Scinto, and Haberer in Summer 2003, during the initial survey of the surface sediment characteristics at Lake Monroe. Because core recovery was imperative to conduct this study, it was these maps, which helped determine which areas of the lake would be ideal to core and analyze. 
Considering that the information, collected from sample and/or coring locations, varies throughout the lake, creating a TIN seemed the appropriate method to build a surface and to ultimately create a contour or isopach map. TIN's were constructed using ESRI's ArcGIS 8.3 3-D Analyst extension. The input layer used for creating each TIN was a shapefile containing all of the attribute data (e.g. lake boundary, latitude, longitude, site ID, water depth, etc.) from each of the 60 sampling locations. The height data source specified for each TIN was dependent on the particular surface being generated. The three height data sources used were water depth, for bathymetric map, and sediment and floc layer thickness, for their respective isopach maps. The proceeding triangulation was performed on mass points with no tag value field. In order to constrain the interpolation to within the boundary of the lake, the extent of interpolation was set to "lake" polygon in 3-D Analyst options. The resultant TIN surface was further converted to a raster grid, utilizing the 3-D analyst "convert TIN to Raster" option.

\subsection{Sediment Coring}

A number of site locations on the lake were identified (Figure 7) from the initial surficial sediment and water depth survey, as being favorable for retrieving sediment cores of appropriate length $(\sim 1 \mathrm{~m})$ and material (OM-rich) for use in future analyses. Those sites which previously exhibited OM-rich surface sediments were targeted for removal, for the OM served as the best medium for analyses. This coring task was carried out on October $23-26,2003$ using the same GPS station coordinates as those used during the initial sediment and water survey.

\subsubsection{Sediment Recovery}

Sediment coring is regarded as the most common method of obtaining paleolimnological data (Cohen, 2003). The goal of sediment coring is to recover an 
undisturbed representative sample, typically including the sediment/water interface, and one of appropriate length and resolution (Glew et al., 2001). This particular study required a collection of 20 intact cores, with a desired minimum recovery depth of 1 meter. A modified Wright-Livingston piston corer (Wright, 1991), with a $5.4 \mathrm{~cm}$ inside

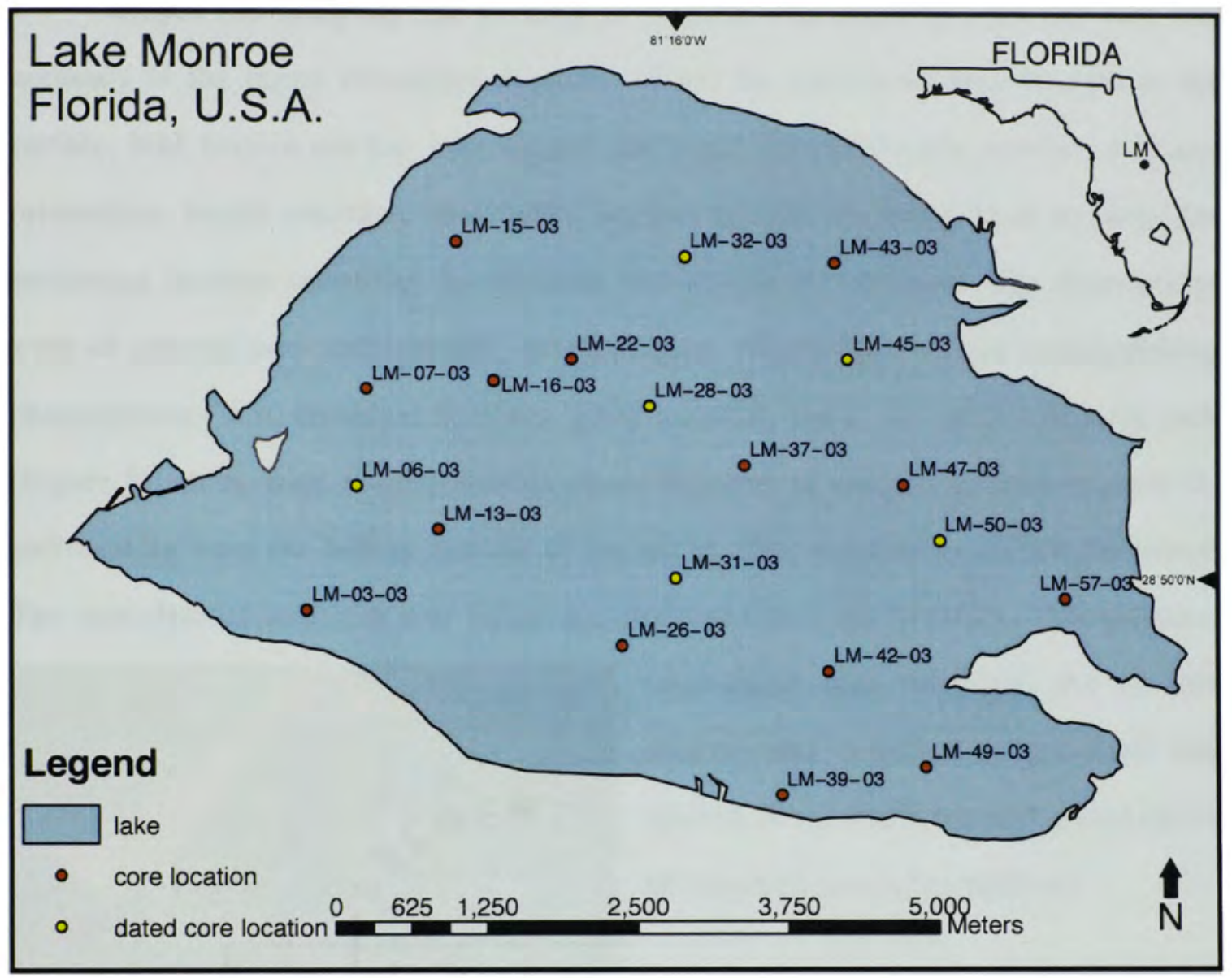

FIGURE 7 Lake Monroe sediment core location map. Sediment was recovered at 20 sites. The yellow sites indicate cores which had intervals dated.

diameter polycarbonate tubing was used. The advantage of using a polycarbonate plastic core tube, instead of a traditional stainless steel core barrel, is that the plastic serves as both a liner and a core barrel. A piston corer uses suction created by a sealed piston, located within the plastic core barrel, and immediately above the removed sediment, to overcome hydrostatic pressure problems which affect other coring systems (Cohen, 
2003), allowing recovery of soft sediment cores with no displacement (Glew et al., 2001).

If the system is properly executed, a long $(>1 \mathrm{~m})$ undisturbed sample may be obtained.

\subsubsection{Field Sampling}

Proper sub-sampling and packing of material was imperative for the ease and accuracy of the future laboratory analyses. Once the intact core was brought to the surface, both bottom and top were capped and taped, labeled for site number, date and orientation, length recorded, and tightly secured upright for travel back to shore for sectioning (portion sampling) by extrusion and written descriptions. The descriptions were of general core stratigraphy, sediment type, fossils present, and distinguishing characteristics (i.e. abundant bivalves, plant material, etc.). A small hydraulic jack (Figure 8), along with wooden dowels (same diameter of core), was used to push the sediment up from the bottom and out of the top in order to be removed and described. The consolidated sediment was raised and sectioned in $3 \mathrm{~cm}$ intervals. The physical

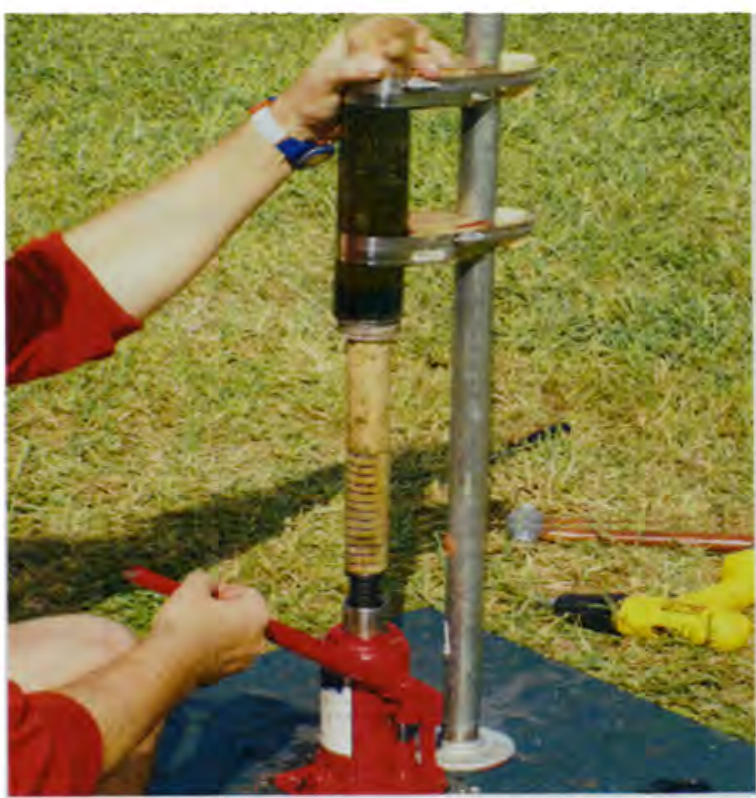

description was recorded, the sample section was sealed in a pre-tared and labeled Whirl-Pak ${ }^{\mathrm{TM}}$ bag and stored on ice for transport and future analyses.

FIGURE 8 Sediment removal system. Hydraulic jack raises measured wooden dowels and rubber plunger through core barrel, pushing sediment up and out of the top. 


\subsection{Sample Preparation}

Upon immediate return to the lab, all samples were removed from Whirl-Pak ${ }^{\mathrm{TM}}$ bags under anerboic conditions in a $\mathrm{N}_{2}$ atmosphere within a sealed glove bag, and placed into $60 \mathrm{ml}$ centrifuge tubes and capped. Samples were then centrifuged at $4000 \mathrm{rpm}$ for 20 minutes at $15^{\circ} \mathrm{C}$ using a Fisher Scientific Marathon 2100R to separate porewater from solids. Porewater was removed and analyzed for nutrients in a related study. The remaining solid pellet sample in the centrifuge tubes was then dried in an oven at $80^{\circ} \mathrm{C}$ for $72 \mathrm{hrs}$. Once dry, all samples were ground to a fine powder. Those samples which were intended for bulk sediment analyses were treated no further, while samples intended for inorganic elemental analyses only, were placed on pre-weighed aluminum crucibles and ashed in a muffle furnace at $550^{\circ} \mathrm{C}$ for 3 hours to effectively burn off all organic material. Samples intended for organic carbon isotope analyses only were pretreated with $1 \mathrm{~N} \mathrm{HCl}$ and rinsed copiously with distilled water to remove remaining chloride until neutral acidity was achieved.

\subsection{Elemental Analyses}

Percent total carbon (\% TC), percent total organic carbon (\%TOC), percent total inorganic carbon (\%TIC), percent total nitrogen (\%TN), and organic content of the sediments, were measured using a Perkin Elmer Series II 2400 CHNS/O Analyzer at the FIU Southeast Environmental Research Center (SERC) Freshwater Biogeochemistry Laboratory. $2.0-2.5 \mathrm{mg}$ of homogenized material was weighed out and analyzed for each $3 \mathrm{~cm}$ interval. Both ashed and non-ashed sediments were analyzed. Standards used were glycine $(32 \% \mathrm{C}, 18.66 \% \mathrm{~N})$ and acetanilide $(71.04 \% \mathrm{C}, 10.36 \% \mathrm{~N})$, with citrus leaves $(43.22 \% \mathrm{C}, 2.74 \% \mathrm{~N})$ as the reference material. Concentrations of TC, TIC, and organic content \% were determined chromatographically on a $\mathrm{CHN} / \mathrm{O}$ analyzer, with TOC determined by difference on a ashed subsample. 


\subsection{Radiometric Analyses}

Three different methods of dating were selected, with each designed to provide a different range of possible ages. Dating techniques using ${ }^{137} \mathrm{Cs}$ (gamma spectrometry) and ${ }^{210} \mathrm{~Pb}$ (alpha spectrometry) were used to date the younger, upper portions of cores (most recent sediments), whereas ${ }^{14} \mathrm{C}$ (accelerated mass spectrometry) was the selected method to date the older or basal portions of the cores. ${ }^{210} \mathrm{~Pb}$ and ${ }^{137} \mathrm{Cs}$ are ideally suited and widely used for measuring high resolution accumulation rates and sedimentological pattern distribution spanning the last 100-150 years (Appleby, 2001; Cohen, 2003), while the relatively new accelerated mass spectrometry (AMS) technique has been developed to effectively date very small amounts of sediment material as well as identified OM, making it ideal for paleolimnological studies. AMS measurements can result in a much better time resolution of the individual samples and of the sediment sequence as a whole (Bjorck and Wohlfarth, 2001), and can date samples up to 50,000 years B.P.

A subset of 6 cores, from the original 20 cores removed, were selected for dating. Cores were selected based on location within the lake, observed stratigraphy, and presence of abundant organic material. Samples from cores LM-06, LM-28, LM-31, LM-32, LM-45, and LM-50B (replicate core to LM-50) were dated at selected intervals. All ${ }^{137} \mathrm{Cs}$ and ${ }^{210} \mathrm{~Pb}$ ages were measured at the St. Croix Watershed Research Station, under the supervision of Daniel Engstrom, while Beta Analytic Inc., located in Miami, Florida, under the supervision of Darden Hood, measured radiocarbon ages. Intervals were chosen based upon sediment type, as well as stratigraphic position.

\subsubsection{Lead-210 $\left({ }^{210} \mathrm{~Pb}\right)$ Dating}

The majority of ${ }^{210} \mathrm{~Pb}$ applications address rapid ecological change and human impacts on lakes and watersheds (Cohen, 2003), such as those subjected upon Lake Monroe post-settlement. Records stored in natural archives, such as lake sediments, 
require accurate or strong chronological control for interpreting the paleolimnological record. ${ }^{210} \mathrm{~Pb}$ dating has proved reliable for both uniform and non-uniform accumulation because it becomes tightly bound to sedimented particles (Appleby, 2001; Cohen, 2003).

For the six cores selected for dating, sediment was analyzed for ${ }^{210} \mathrm{~Pb}$ (half-life 21.6 yrs.) (Cohen, 2003) activity by alpha spectrometry, through its granddaughter product ${ }^{210} \mathrm{Po}$ at incremental $3 \mathrm{~cm}$ intervals between the depths of $9-30 \mathrm{~cm} .0 .2-1.2 \mathrm{~g}$ of the isotope ${ }^{210} \mathrm{Po}$ was extracted from the dry sample by chemical digestion and plated onto silver planchets for assay in a low-background alpha spectrometer (Appleby, 2001).

${ }^{210} \mathrm{~Pb}$ occurs naturally as one of the radionuclides in the ${ }^{238} \mathrm{U}$ decay series following the progression below:

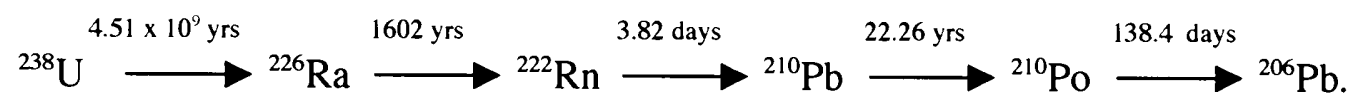

An intermediate isotope ${ }^{226} \mathrm{Ra}$ exists in soils and exposed bedrock in trace amounts. As ${ }^{226} \mathrm{Ra}$ decays it is transformed into the gas ${ }^{222} \mathrm{Rn}$ which moves into the atmosphere (Cohen, 2003). ${ }^{210} \mathrm{~Pb}$ forms in the atmosphere by the decay and release of ${ }^{222} \mathrm{Rn}$, becomes readily attached to airborne particulate matter, and falls out by precipitation or dry deposition as unsupported ${ }^{210} \mathrm{~Pb}$ onto land or water (Appleby, 2001). ${ }^{210} \mathrm{~Pb}$ activity in sediment records is identified as either unsupported ${ }^{210} \mathrm{~Pb}$, derived from atmospheric flux, or supported ${ }^{210} \mathrm{~Pb}$, which derives from the in situ decay of the parent radionuclide ${ }^{226} \mathrm{Ra}$.

Unsupported ${ }^{210} \mathrm{~Pb}$ was calculated by subtracting supported activity from the total activity maeasured at each interval, with supported ${ }^{210} \mathrm{~Pb}$ estimated from the asymptotic activity at depth (the mean of the lowermost three samples in the core). Dates and sedimentation rates were calculated using either the constant rate of supply (c.r.s.) model, or the constant flux: constant sedimentation (cf:cs) model. The c.r.s. model assumes: 1) the rate of deposition of unsupported ${ }^{210} \mathrm{~Pb}$ from the atmosphere is constant, 2) ${ }^{210} \mathrm{~Pb}$ in 
fresh waters is quickly removed from solution onto particulate matter, and 3) the initial unsupported ${ }^{210} \mathrm{~Pb}$ activity in sediments is not redisturbed or redistributed by postdepositional processes, and decays exponentially with time (Appleby, 2001). Conversely, the cf:cs model assumes a constant flux of unsupported ${ }^{210} \mathrm{~Pb}$, but unlike the c.rs. model, additionally assumes a constant sedimentation rate. Therefore, the cf:cs model fits best only to those cores in which the ${ }^{210} \mathrm{~Pb}$ profile declines exponentially, indicating a constant sediment flux.

\subsubsection{Cesium-137 $\left({ }^{137} \mathrm{Cs}\right)$ Dating}

The radiocesium method, performed following ${ }^{210} \mathrm{~Pb}$ analyses, was used on the three cores (LM-28, LM-31, LM-32) which first demonstrated the most reliable ${ }^{210} \mathrm{~Pb}$ records. ${ }^{137} \mathrm{Cs}$ was measured in only 5-7 sections of each of the three cores to verify the post World War II profile of atmospheric ${ }^{137} \mathrm{Cs}$ fallout associated with the atmospheric testing of nuclear weapons during the 1950 's. ${ }^{137} \mathrm{Cs}$ is a mobile radionuclide (not tightly bound to sediment) and therefore at times difficult to interpret (Cohen, 2003). Because of this, only select intervals were chosen at the discretion of Daniel Engstrom, where supported activity could be measured best.

Cesium-137 activity was measured using an Ortec-EGG (Oak Ridge TN) HighPurity, Germanium Crystal Well, Photon Detector (Well Detector) coupled to a Digital Gamma-Ray Spectrometer (Dspec). Plastic tubes containing the samples were placed in the detector well and ${ }^{137} \mathrm{Cs}$ activity was counted for 7-20 x 104 seconds. Cesium-137 activity was quantified using GammaVision (Ortec, Oak Ridge TN) software, which incorporates user defined energy and efficiency standard calibrations. An energyefficiency calibration (i.e. activity calibration) curve was previously prepared using a suite of analytical grade radioisotope standards, including ${ }^{137} \mathrm{Cs}$, encompassing a range of gamma emission energies from $46 \mathrm{kev}$ to $1460 \mathrm{kev}$ (kiloelectron volts). The energy- 
efficiency calibration compares the known activity (decay) of the standards to the counting efficiency of the detectors over the range of emission energies, and GammaVision develops a polynomial curve equating this relationship (Anderson et al., 2005).

${ }^{137} \mathrm{Cs}$ is the most widely used independent dating technique from sediment records of artificial radionuclides (Appleby, 2001). Paleolimnologists can use the occurrence of this isotope as a geochrometric time marker in lake sediments, possibly observing the spike in the radioactivity profile at or around 1963, the period of maximum fallout accumulation (Appleby, 2001; Cohen, 2003). Where there is a qualitative record of atmospheric fallout, sediments recording these events can be dated (Appleby, 2001).

\subsubsection{Carbon-14 $\left({ }^{14} \mathrm{C}\right)$ Dating}

Radiocarbon techniques are based on the decay rate of ${ }^{14} \mathrm{C}$ in organic tissues, which prior to death and deposition, are readily absorbed by water bodies and living organisms. Upon death or burial of an organism, ${ }^{14} \mathrm{C}$ no longer is assimilated into organic tissues but rather begins to undergo radioactive beta-decay. It is this decay which is measured and utilized when determining the age of the expired OM.

Organic matter samples for AMS radiocarbon dating, were selected from basal sample intervals from cores: LM-06, LM-28, LM-31, LM-32, and LM-45. Two bulk samples were selected from LM-50B, bracketing a marl, and the upper sample was immediately below the upper most OM rich layer of gyttja. All AMS samples were pretreated with multiple treatments of hot (sub-boiling) $1 \mathrm{~N} \mathrm{HCl}$ for 2 to $3 \mathrm{hrs}$ to remove carbonates, and to ensure that only organic carbon was analyzed. All $\mathrm{HCl}$ treatments were repeated 2 to 10 times depending on a sample's carbonate content, and until the sample showed no physical reaction. Materials measured by the radiometric technique are analyzed by synthesizing sample carbon to benzene $(92 \% \mathrm{C})$, measuring for ${ }^{14} \mathrm{C}$ 
content in a scintillation spectrometer, and then calculating radiocarbon age. AMS results are derived from reduction of sample carbon to graphite $(100 \% \mathrm{C})$, along with standards and backgrounds. The graphite is then detected for ${ }^{14} \mathrm{C}$ in an AMS.

\subsection{Stable Isotope Analyses}

Stable isotope geochemistry, used in the study of ecosystems, is mainly focused on the variations of only five elements: H, C, N, O, and S (Peterson and Fry, 1987), which happen to comprise the bulk of tissues in living organisms. Here, analyses and methods will be focused solely on the variations of the isotopes of carbon and nitrogen in the sedimented OM of Lake Monroe, with these variations being measured with a high degree of precision using a mass spectrometer.

Carbon and nitrogen isotope values of bulk organic matter were determined by standard elemental analyzer (EA) isotope ratio mass spectrometry (IRMS) procedures at Florida International University's SERC Stable Isotope Laboratory. Elemental composition and gases for isotopic analysis were obtained using an EA to combust organic matter to form both $\mathrm{N}_{2}$ and $\mathrm{CO}_{2}$ gases, which were then measured on a Finnigan MAT Delta $\mathrm{C}$ mass spectrometer in continuous flow mode. Nitrogen isotopic analysis was performed on a bulk sample, while the carbon isotopic analysis was performed on a de-carbonated ( $\mathrm{HCl}$ treated) sample.

Carbon and nitrogen have two light stable isotopes, conventionally written as the ratio (R) of the heavy isotope to the light isotope (i.e. ${ }^{13} \mathrm{C} /{ }^{12} \mathrm{C},{ }^{14} \mathrm{~N} /{ }^{15} \mathrm{~N}$ ) (Hoefs, 1997). Additionally, each one of these isotopes has certain abundances in nature. For example, ${ }^{12} \mathrm{C}$ and ${ }^{14} \mathrm{~N}$, both the lighter isotopes of carbon and nitrogen respectively, make up approximately $99 \%\left({ }^{12} \mathrm{C}=98.89 \%,{ }^{14} \mathrm{~N}=99.63\right)$ of all carbon and nitrogen compounds (Hoefs, 1997) in nature. Considering that both carbon and nitrogen naturally occur in various reduced or oxidized states, this makes them ideal elements for the search of 
natural variations in biological materials (Hoefs, 1997). The measured range of both carbon and nitrogen isotope compositions in nature are over $100 \%$, with most $\delta$ values falling within the range of $-40 \%$ to $10 \%$ (Hoefs, 1997). Stable isotopes from different reservoirs have distinct isotopic signatures, and are considered ideal tracers of organic matter (Peterson and Fry, 1987). This approach therefore can be used to not only determine sources of allochthonous vs autochthonous material, but also the abundances of these organisms in the organic material.

Accumulation rates and temporal changes in $\delta^{13} \mathrm{C}$ of $\mathrm{OM}$ have been used in lacustrine sediment studies as reliable indicators of primary production (McKenzie, 1985; Schelske and Hodell, 1991). In addition to carbon isotopes, nitrogen isotopes have proved to be an additional approach to recording changes in productivity within lakes (Lehmann et al., 2004; Meyers and Lallier-Verges, 1999; Terranes and Bernasconi, 2000). Paleolimnological information about the origins of sedimented organic matter can potentially be obtained from $\delta^{15} \mathrm{~N}$ values, as they faithfully record environmental changes (Meyers and Lallier-Verges, 1999).

An important parallel to this relationship between productivity and isotopes is the requirement of a sufficient supply of nutrients to promote production of OM (McKenzie, 1985). Modern pollution, such as wastewater discharge, contaminated groundwater, and surface water runoff with the basin are suspected of providing these nutrients to the lake (SJRWMD, 2002) but to what extent and for how long is currently undetermined. By withdrawing sediment cores from Lake Monroe and examining the isotopic composition of the OM, an archive of lake productivity and source materials may be be inferred (Schelske and Hodell, 1991, 1995), as both $\delta^{13} \mathrm{C}$ and $\delta^{15} \mathrm{~N}$ can be used as productivity and source material indicators (Meyers, 1997). 


\section{RESULTS}

\subsection{Lake Sediment and Water Survey}

The sediments recovered at Lake Monroe included a mixture of sediment types with compositions primarily made up of: floc, gyttja, sand/clay/marl (SCM), and peat. Gyttja, SCM, and peat were the only consolidated sediments encounterd (Figure 9), and averaged in depth of $134 \mathrm{~cm}$. Floc formed a fluid mud layer overlying the sediments to an average depth of $7.6 \mathrm{~cm}$. The spatial distribution of these sediments varied and showed no discernible pattern. Data for all sediment, floc, and water depth measurements are shown in Table A-1.

Floc (fluid-mud), a dark-brown, unconsolidated, water-rich sediment was found at the sediment-water interface in 52 of the 60 cores, thus covering $80 \%$ of the lakebed. The average fractional water content for the floc sediments, determined by water content analyses, was $81 \%$. Thicknesses of these layers ranged from $0-20 \mathrm{~cm}$ (average 7.6) and often contained fossils of whole and broken mollusks. The floc layer behaved like a fluid when extruded from the core due to high water content, and would flow off the top as the sediment was pushed upwards.

Gyttja, an organic-rich, fine-grained, semi-consolidated sediment, was found at 43 of the 60 sites. Gyttja is commonly referred to in the field of limnology as a copropel. Both terms are synonymous for a fine-grained organic sediment, made up primarily of a mixture of humus material, algal remains, and fecal material. This sediment is derived mainly from the plankton within the water column, but benthic fauna also mix it by both consuming and excreting the sediment. Gyttja, or copropel, has become known as the type sediment for eutrophy due to the presence of abundant algal material, suggesting dominate algal productivity which occurs in eutrophic systems (Cole, 1994). In Lake Monroe, this sediment was dark brown to black, and contained numerous mollusk shells, 


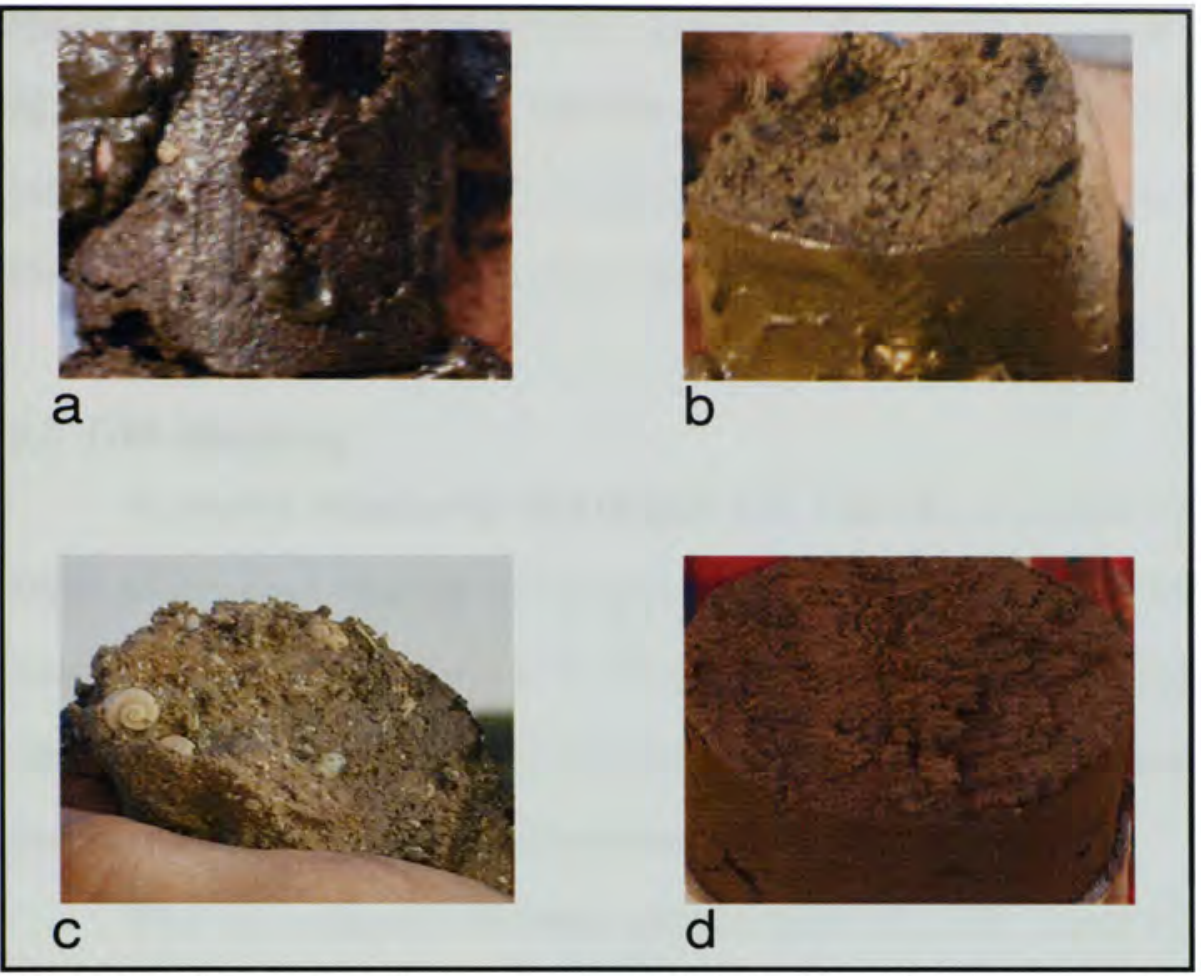

FIGURE 9 Three major sediment types identified during lake sediment survey: a) dark brown gyttja, b) light brown gyttja, c) SCM and d) fibric peat.

both whole and fragmented, which likely fell through the water column and unconsolidated floc layer only to be deposited in the upper gyttja layers.

The bottommost sediment found in 17 of the 60 sites was a well-consolidated, organic-rich, brown fibric peat layer. Peat layers contained abundant visible plant material, and when extruded from core obtained its original shape very well. Weight of overlying sediments has forced water out of the peat, leaving a fairly dry and consolidated sediment. A variety of other sediment types of various abundances were found and described. Thin sand layers $(\operatorname{avg}=0.9 \mathrm{~cm})$ were found in 9 of the 60 sites sampled, These sands were described as fine-grained light-brown/brown sand (Anderson et al., 2003), and their thickness ranged from 0-4 cm. Finer sediments, such as sticky gray clay were also found. Gray clay layers were found in 11 of the 60 sites at Lake Monroe. Clay was found mixed in with other sediment types, forming sandy clays and 
clayey marls. Shelly marl layers were present in 9 of the 60 sites with 6 of the sites (LM28, LM-37, LM-47, LM-50, LM-60) aligned next to each other forming a transect extending from the lake inlet (see Figure 5 for core locations) into the middle of the lake. Marls are soft calcareous sediments comprised mostly of $\mathrm{CaCO}_{3}$.

\subsection{GIS Mapping}

A shaded bathymetric map (Figure 10), with $50 \mathrm{~cm}$ contour lines, depicted water depth within Lake Monroe and revealed the general basin shape. Average water depth was $214 \mathrm{~cm}$ with a maximum of $275 \mathrm{~cm}$ occurring near the geographic middle of the lake. Lake Monroe displayed a typical shallow lake morphometry, with shallowest depths in the littoral zones and increasing towards the center.

Floc and sediment thickness isopach maps (Figures 11 and 12) show the relative distribution of sediments throughout the lake, which the contours suggest is greatest in the southern half of Lake Monroe. Maximum sediment and floc depths of $250 \mathrm{~cm}$ and 20 $\mathrm{cm}$ respectively are displayed on maps.

\subsection{Sediment Cores}

Sediment cores recovered from 20 sites (see Figure 7) ranged in length from 15 $70 \mathrm{~cm}$, and yielded a variety of sediment types. Full recovery at every site was inhibited by field conditions such as wind (boat drift), substrate (hard sand layers) and depth to bedrock. Regardless, sediment type and length was satisfactory for furture geochemical and radiometric analyses.

Sediment types recovered were similar to those encountered during intial surficial sediment survey. The prominent sediments recovered were comprised of three main types : 1) gyttja, 2) peat, and 3) SCM. Unconsolidated floc was present at the sediment water interface, overlying the gyttja, in 17 of the 20 cores. Floc depth average $7.6 \mathrm{~cm}$. 


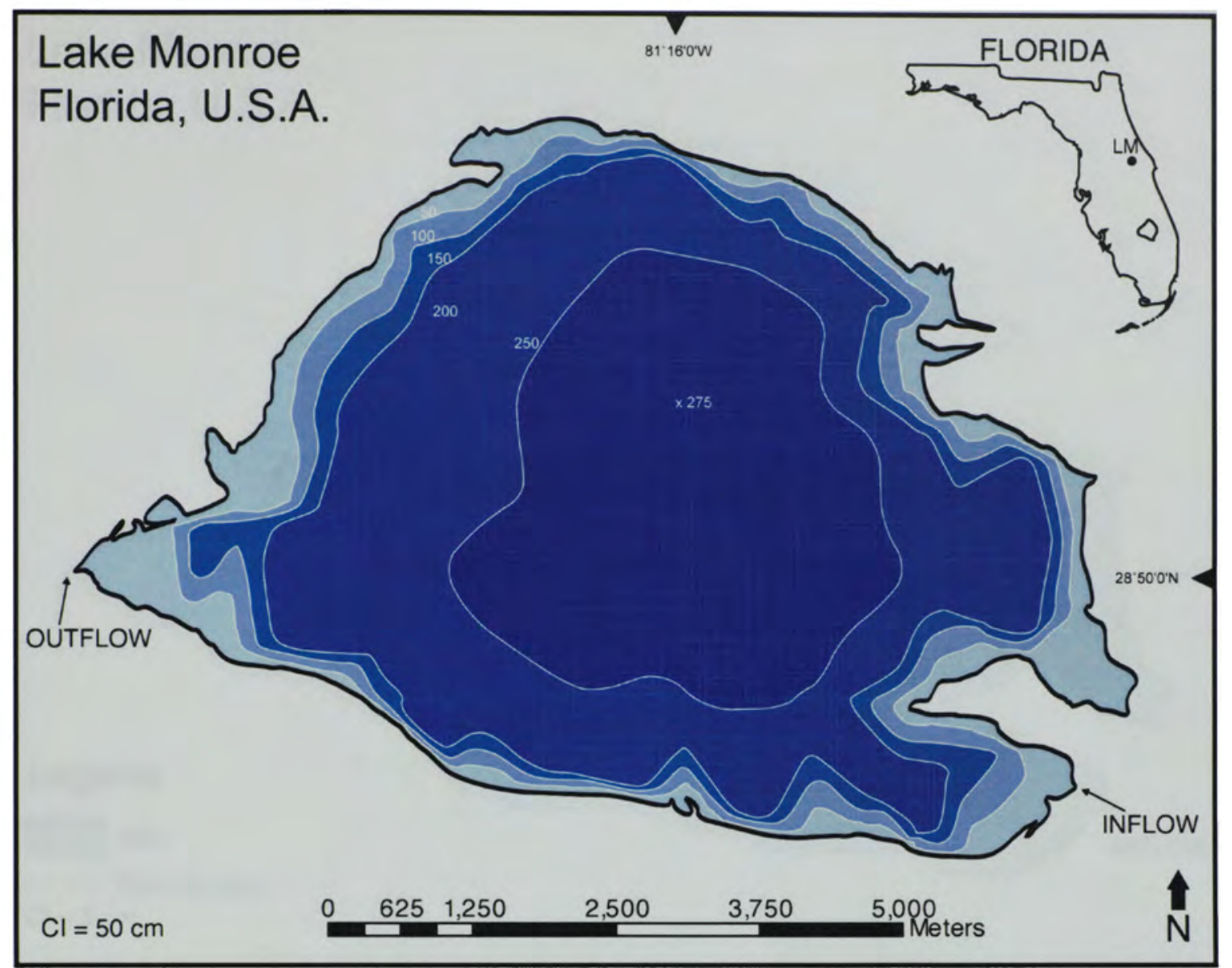

FIGURE 10 Lake Monroe shaded bathymetric map with $50 \mathrm{~cm}$ contour interval. Location of deepest measurement of water depth is marked with an $\times$.

Gyttja was present in the uppermost intervals in 18 of the 20 cores removed, and often contained numerous whole or fragmented mollusk shells. Gyttja was underlain by peat sediments, which were found in the basal portion of 12 of the 20 cores and in 5 of the 6 dated cores. Thicknesses of peat layers ranged from $10 \mathrm{~cm}-72 \mathrm{~cm}$. The peats were fibric and dry, and the presence of parts of plants and roots was not uncommon in these sediments. Peats were classified in the field based on appearance, but were not further sub-divided into peat type or depositional environment. 


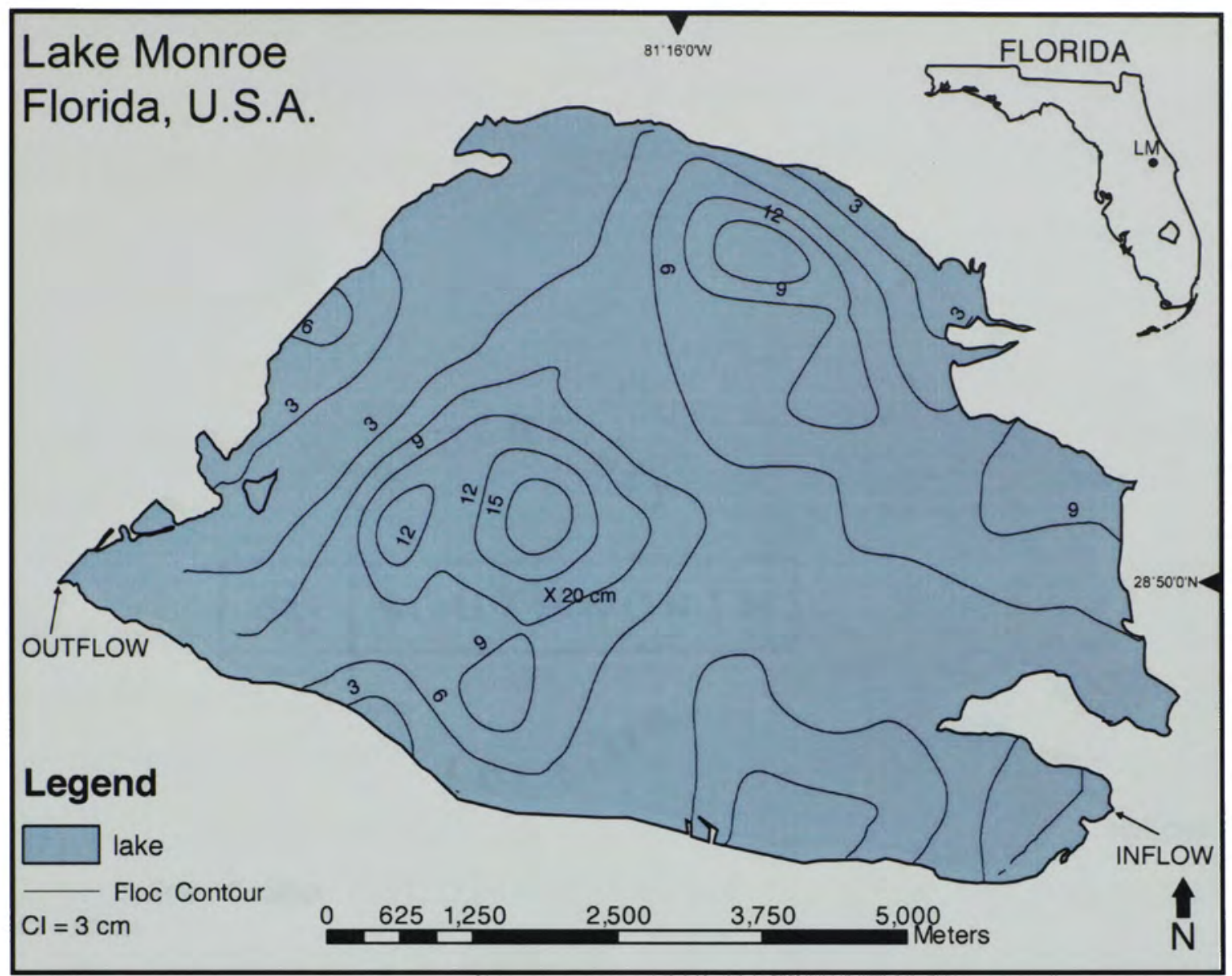

FIGURE 11 Lake Monroe floc thickness map with $3 \mathrm{~cm}$ contour interval. Location of greatest recorded measurement is marked with an $\times$.

\subsection{Sediment Stratigraphy}

A generalized sediment stratigraphy showing length, sediment type, and number of samples removed for various geochemical and radiometric analyses, revealed the pattern of deposition at Lake Monroe. Of the 20 sediment cores recovered, 15 displayed a similar stratigraphy in which upper gyttja sediments overlied peat (Figure 13). Those cores (LM-15, LM-28, LM-37, LM-50B, LM-57) which did not display this stratigraphy were found to have clay layers of various depths as the bottom-most sediment. 


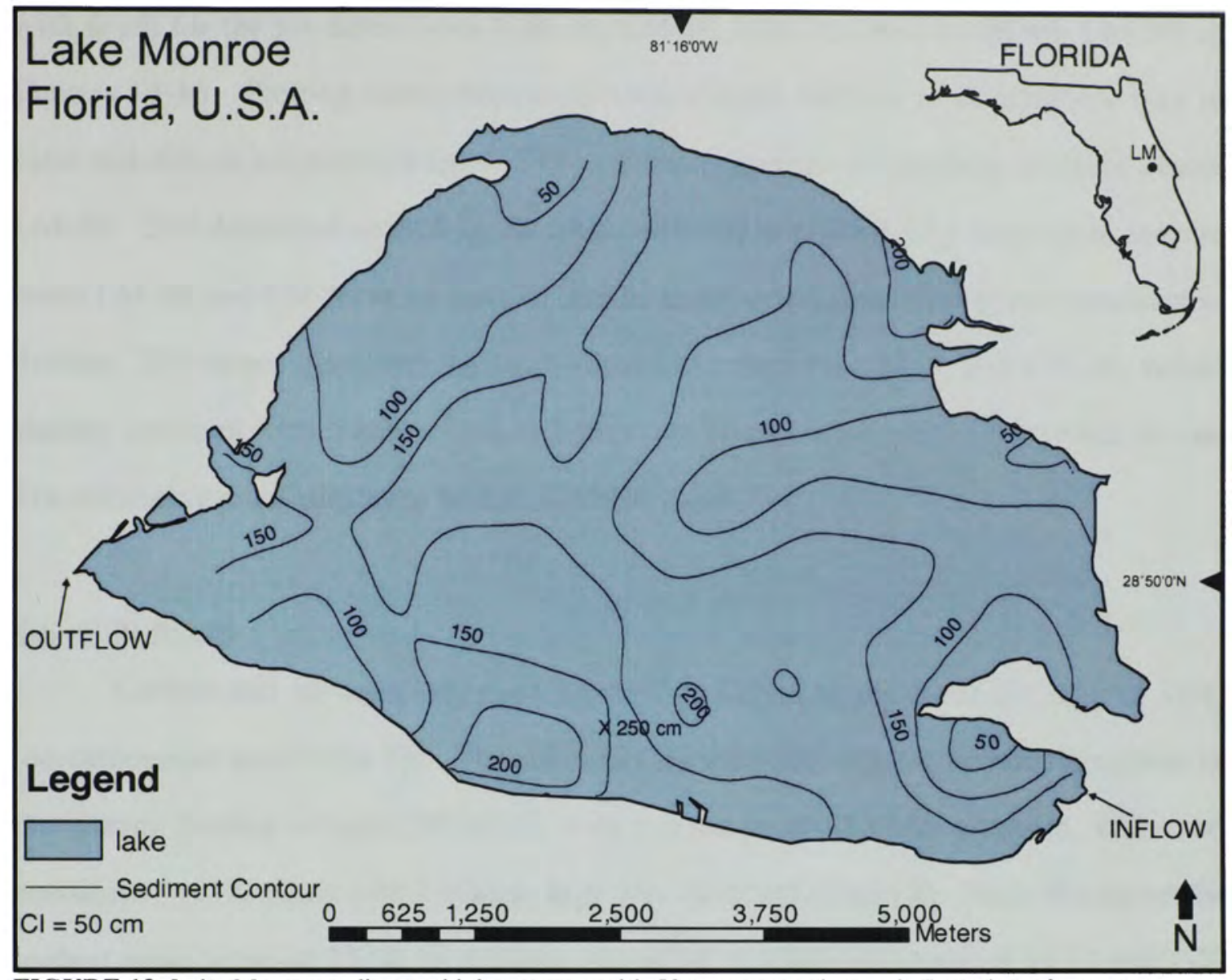

FIGURE 12 Lake Monroe sediment thickness map with $50 \mathrm{~cm}$ contour interval. Location of greatest recorded measurement is marked with an $\times$.

\subsection{C and N Analysis}

Nutrient analyses were performed on 20 cores, and at incremental $3 \mathrm{~cm}$ intervals.

The results for carbon and nitrogen for both ashed and non-ashed samples are given as $\% \mathrm{TC}, \% \mathrm{TIC}, \% \mathrm{TOC}$, and \%TN, with TOC determined by difference (Table A-2).

Several upper intervals were unable to be analyzed for lack of sufficient material. Viewing the results by sediment type (Table 2) elucidates the range of values between sediments as well as which sediments contain the highest/lowest proportions of $\mathrm{C}$ and $\mathrm{N}$. Results show that the peat sediments have the highest mean values of TOC and N, while SCM represented the highest mean value of TIC. \% TIC, $\% \mathrm{TOC}$, and $\% \mathrm{~N}$ are plotted 
with depth for the six dated cores (LM-06, LM-28, LM-31, LM-32, LM-45, LM-50) in Figures 14-16. Plotting these parameters versus depth and age is an effective way to view and discern temporal changes. TOC values increased with depth in all cores except LM-28. TIC decreased overall in all cores, with the exception of a large peak seen in cores LM-45 and LM-50 at $33 \mathrm{~cm}$. At depths below this peak, TIC values continued to decline. TN values displayed the most variability. In cores LM-06 and LM-28, values sharply declined with depth, and core LM-31 declined with depth only beyond $20 \mathrm{~cm}$. The remaining cores displayed higher values at depth.

\subsection{C/N Ratio}

Carbon and nitrogen ratios are reported as $\mathrm{C} / \mathrm{N}$, and represent the ratio of TOC (de-carbonated sample) to TN. The ratios demonstrate that organic carbon dominates in the system, leading to high $\mathrm{C} / \mathrm{N}$ values, with an average of 10.37 for all cores. Observed variations in $\mathrm{C} / \mathrm{N}$ ratios with sediment type was observed (Table 2). Peats displayed the highest mean value of 13.20, with gyttja and SCM each having values of 11.77 and 7.20 respectively. The highest $\mathrm{C} / \mathrm{N}$ values, in cores $\mathrm{LM}-06$ and $\mathrm{LM}-28$, corresponded with the upper $12 \mathrm{~cm}$ (Figure 14), while cores LM-31, LM-32, LM-45, and LM-50 (Figures $15,16)$ all showed a relative increase with depth. Maximum $\mathrm{C} / \mathrm{N}$ values were reached at depths greater than $45 \mathrm{~cm}$ in cores LM-31 and LM-32, and greater than $30 \mathrm{~cm}$ in cores LM-45 and LM-50.

\subsection{Lead-210 $\left({ }^{210} \mathrm{~Pb}\right)$}

In view of the documented environmental changes which have taken place over the past 150 years along the St. Johns River and within the MSJRB, rates of erosion, and sediment and nutrient accumulation are likely to have varied significantly at times. Where this has occurred, ${ }^{210} \mathrm{~Pb}$ activity will vary with depth and ${ }^{210} \mathrm{~Pb}$ profiles will be 


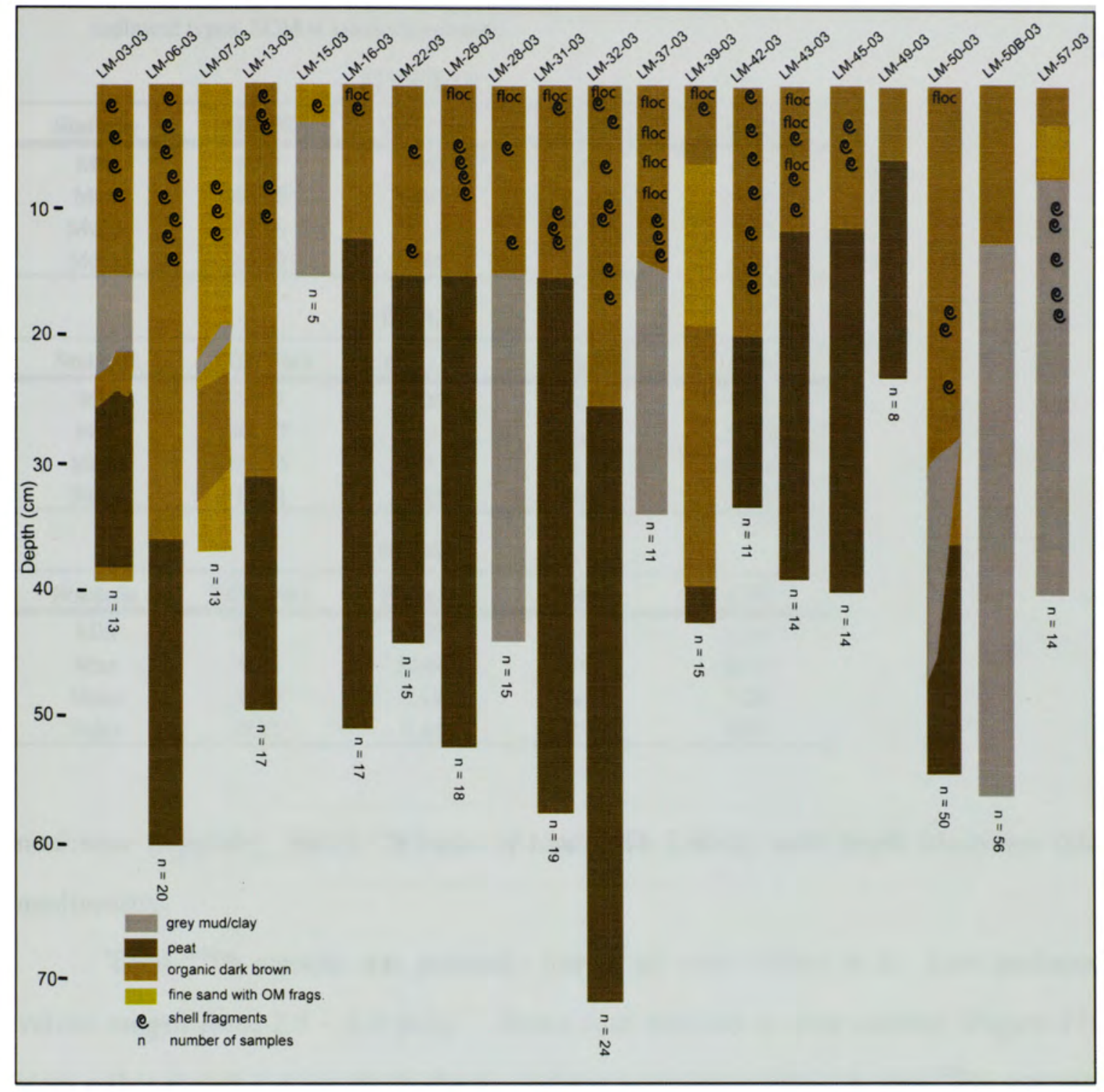

FIGURE 13 Lake Monroe generalized stratigraphy. Twenty (20) cores were removed on October 23-26, 2003 and visually described through upwards extrusion and sub-sampling. 
TABLE 2 Lake Monroe sediment chemistry statistical results for selected sediment types. $\mathrm{SCM}=$ sands/clays/marls.

GYTTJA

\begin{tabular}{ccccc}
\hline Statistic & TOC $(\%)$ & TIC $(\%)$ & TN(\%) & C/N \\
\hline \hline Min & 0.74 & 0.05 & 0.09 & 1.88 \\
Max & 43.82 & 9.02 & 3.86 & 15.86 \\
Mean & 18.48 & 1.33 & 1.73 & 11.77 \\
Stdev & 14.29 & 1.56 & 1.10 & 3.44 \\
\hline \multicolumn{5}{c}{ PEAT } \\
\hline Statistic & TOC $(\%)$ & TIC $(\%)$ & TN(\%) & C/N \\
\hline \hline Min & 6.19 & 0.09 & 0.65 & 9.60 \\
Max & 46.17 & 10.17 & 4.40 & 17.32 \\
Mean & 28.85 & 0.93 & 2.57 & 13.20 \\
Stdev & 13.51 & 1.23 & 0.97 & 2.64 \\
\hline & & & & \\
& & SCM & TN $(\%)$ & C/N \\
\hline Statistic & TOC $(\%)$ & TIC $(\%)$ & 0.01 & 1.36 \\
\hline \hline Min & 0.01 & 0.02 & 0.95 & 24.33 \\
Max & 0.95 & 10.66 & 0.39 & 7.20 \\
Mean & 0.36 & 4.14 & 0.35 & 4.80 \\
Stdev & 0.32 & 4.44 &
\end{tabular}

nonlinear (Appleby, 2001). Results of total ${ }^{210} \mathrm{~Pb}$ activity with depth illustrates this nonlinearity.

Total ${ }^{210} \mathrm{~Pb}$ activity was generally low in all cores (Table A-3). Low surfaces values ranged from $2.8-6.0 \mathrm{pCig}^{-1}$. Down core declines in total activity (Figure 17) were rather abrupt and are likely due to changes in sediment lithology and ${ }^{226} \mathrm{Ra}$ content. In some instances (LM-06, LM-31), total activity even showed reversals at depth. High ${ }^{210} \mathrm{~Pb}$ activities in the recent surficial sediments, as opposed to basal sediments, derive from their exposure to recent inputs from the atmosphere (Appleby, 2001). In cores LM28, LM-31, LM-32, and LM-50B, background (supported ${ }^{210} \mathrm{~Pb}$ ) activity values were reached between 13-21 cm, while cores LM-06 and LM-45 reached background activity values only between $6-9 \mathrm{~cm}$. The low background values which were exhibited in all 


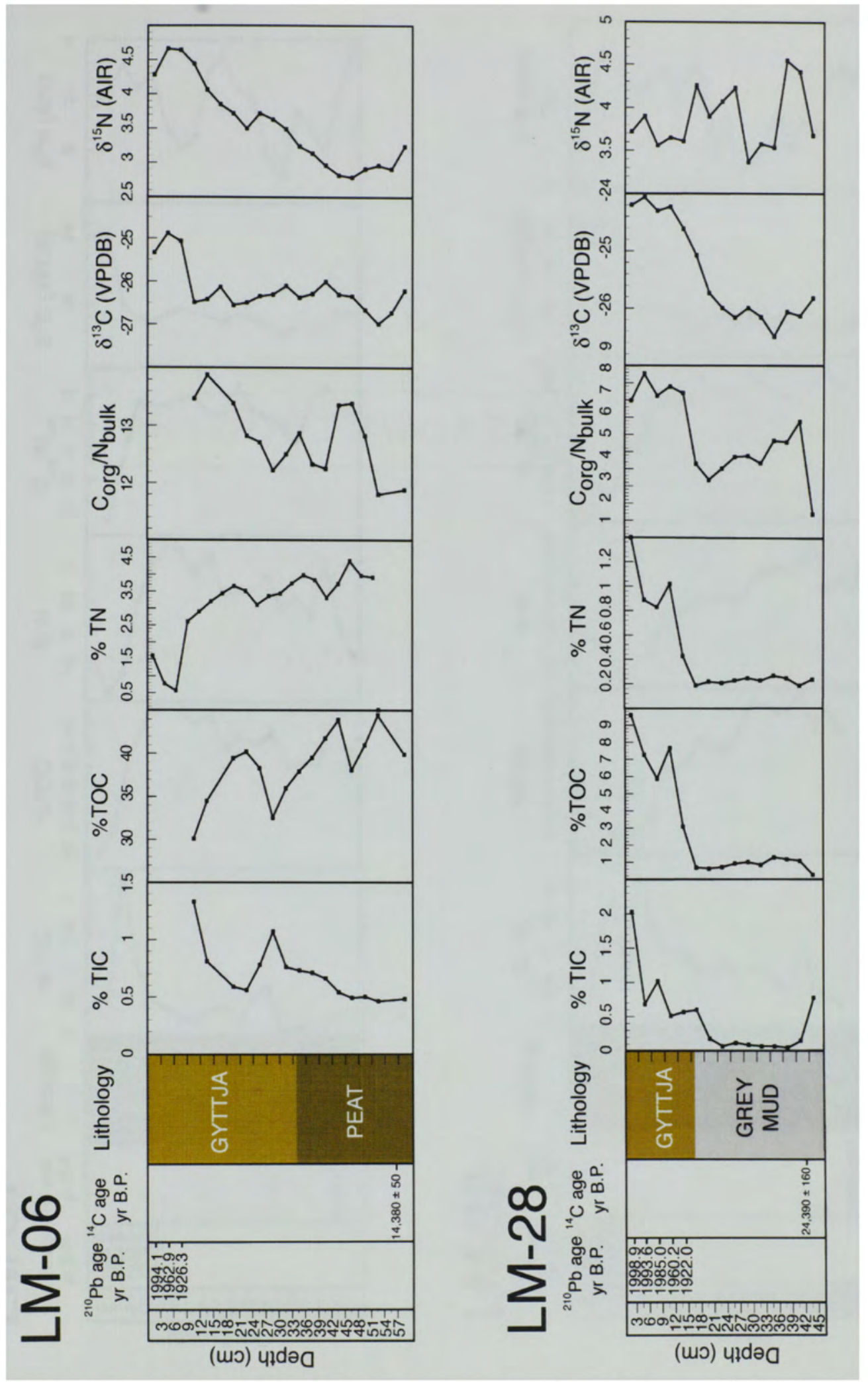

FIGURE $14 \mathrm{TIC}, \mathrm{TOC}, \% \mathrm{~N}, \mathrm{C} / \mathrm{N}, \delta^{13} \mathrm{C}, \delta^{15} \mathrm{~N}$ plotted with depth, radiometric age, and lithology for cores LM-06, LM-28. 


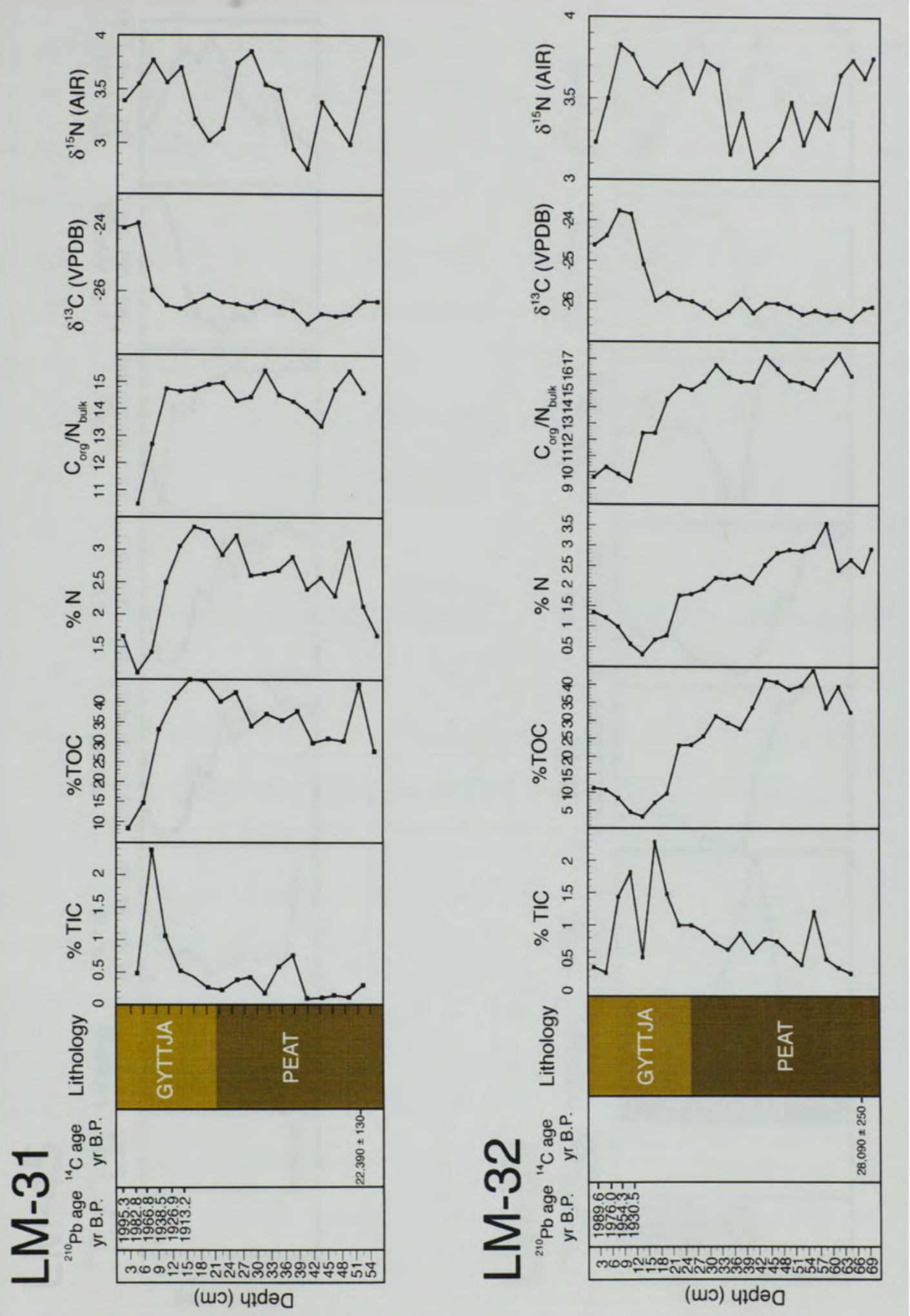

FIGURE 15 TIC, TOC, $\% \mathrm{~N}, \mathrm{C} / \mathrm{N}, \delta^{13} \mathrm{C}, \delta^{15} \mathrm{~N}$ plotted with depth, radiometric age, and lithology for cores LM-31, LM-32. 


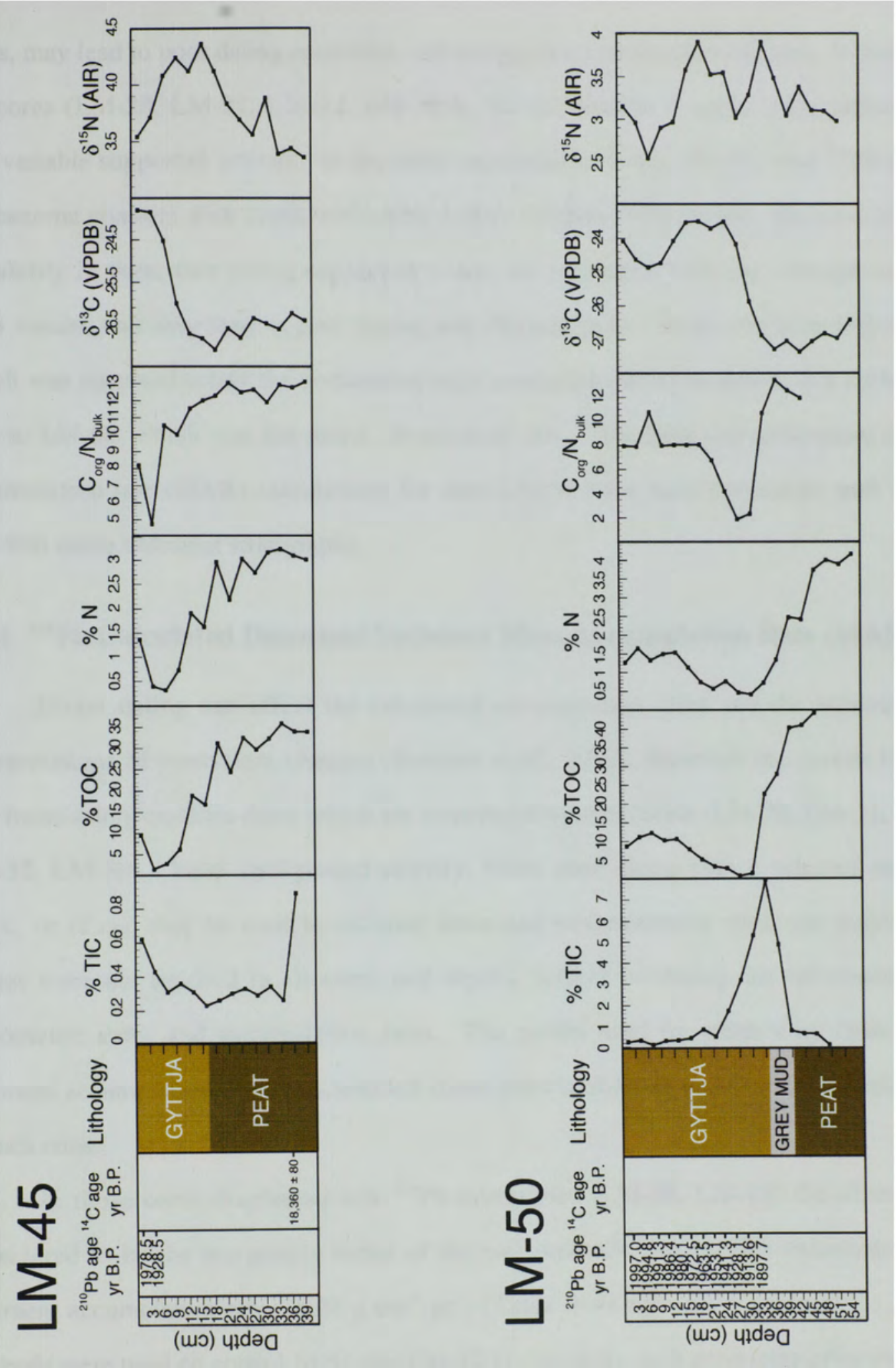

FIGURE 16 TIC, TOC, $\% \mathrm{~N}, \mathrm{C} / \mathrm{N}, \delta^{13} \mathrm{C}, \delta^{15} \mathrm{~N}$ plotted with depth, radiometric age, and lithology for cores LM-45, LM-50. 
cores, may lead to poor dating resolution and uncertainties in the chronologies. In four of the cores (LM-28, LM-31, LM-32, LM-50B), the delineation is quite clear indicating non-variable supported activity. In the other two cores (LM-06, LM-45) total ${ }^{210} \mathrm{~Pb}$ does not become constant with depth, indicating a more variable ${ }^{210} \mathrm{~Pb}$ profile. Because of the variability in these two cores, supported values are estimated from the average of the ${ }^{210} \mathrm{~Pb}$ values, and may lead to poor dating and chronologies. Note that core LM-50B, which was removed solely for performing high resolution dating analyses, is a replicate core to LM-50, which was not dated. Because of this, ${ }^{210} \mathrm{~Pb}$ dates and subsequent mass accumulation rate (MAR) calculations for core LM-50 have been correlated with core LM-50B using sediment stratigraphy.

\subsection{1 ${ }^{210} \mathrm{~Pb}$ Calculated Dates and Sediment Mass Accumulation Rate (MAR)}

Errant dating can affect the calculated accumulation rates and the subsequent interpretations of ecosystem changes (Brenner et al., 1999), therefore the results listed will focus solely on those dates which are considered most accurate (LM-28, LM-31, LM-32, LM-50). Total background activity, when used along with a selected model (c.r.s., or cf:cs), may be used to calibrate dates and sedimentation rates, yet supported values were not reached in all cores and depths, further inhibiting the calculation of radiometric dates and accumulation rates. The model used for calibrating dates and sediment accumulation rates was selected consequent to the supported activity displayed in each core.

In those cores displaying low ${ }^{210} \mathrm{~Pb}$ inventories (LM-06, LM-45) the cf:cs was considered to be the marginally better of the two methods, yet yielded extremely low sediment accumulation rates $\left(0.01 \mathrm{~g} \mathrm{~cm}^{-2} \mathrm{yr}^{-1}\right)$ (Table A-4) not worth considering. Both methods were used on cores LM-31 and LM-32 (Table A-5), each producing effectively similar results with slightly greater sedimentation rates $\left(0.02-0.04 \mathrm{~g} \mathrm{~cm}^{-2} \mathrm{yr}^{-1}\right)$ than those 


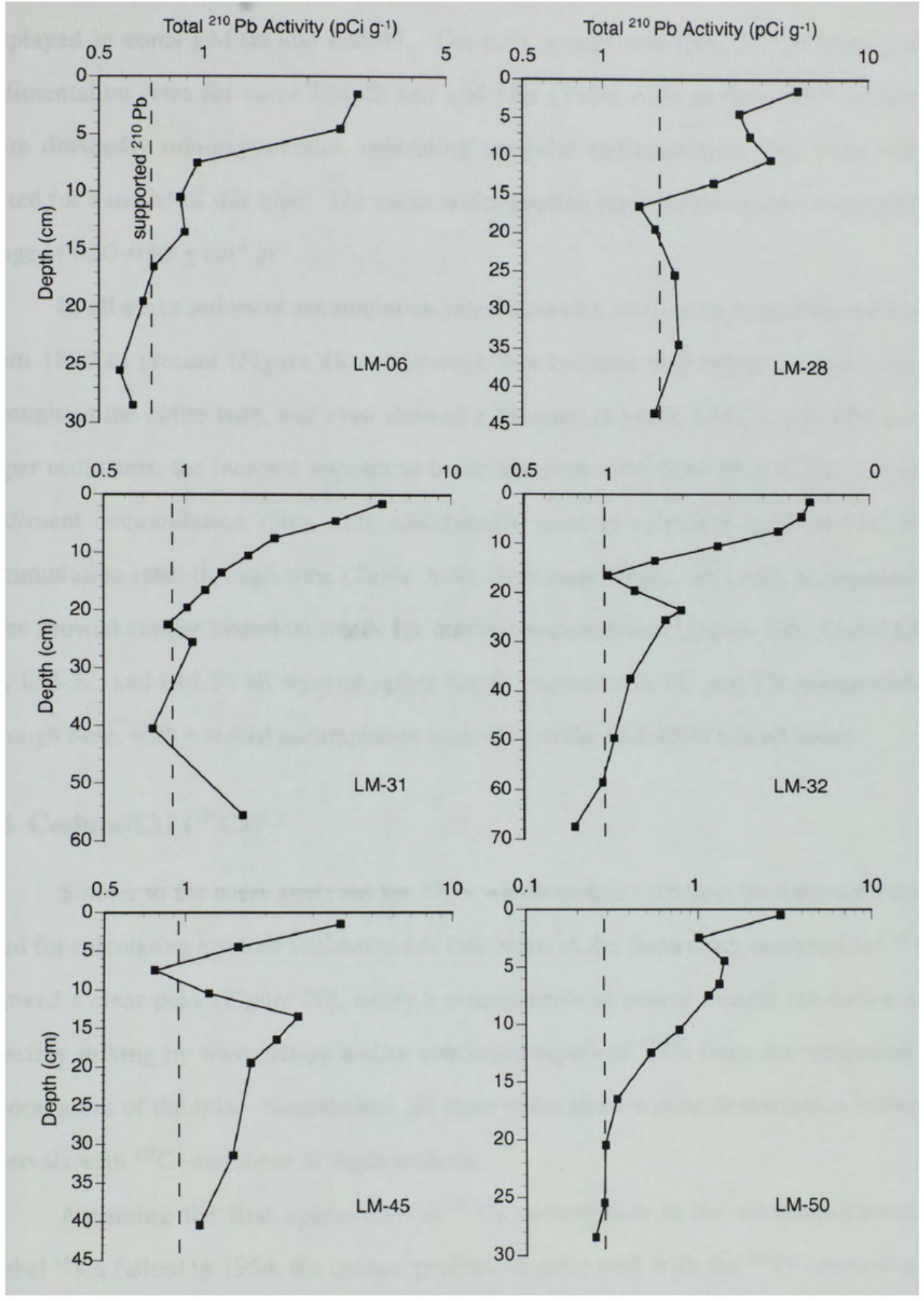

FIGURE 17 Lake Monroe total ${ }^{210} \mathrm{~Pb}$ activity for selected six cores. Dashed line represents supported activity. 
displayed in cores LM-06 and LM-45. The c.r.s. model was used for calculating the sedimentation rates for cores LM-28 and LM-50B (Table A-5) as their ${ }^{210} \mathrm{~Pb}$ activities were decidedly non-exponential, indicating irregular sedimentation, and were better suited for a model of this type. The mean sedimentation rates for these cores were in the range of $0.03-0.08 \mathrm{~g} \mathrm{~cm}^{-2} \mathrm{yr}^{-1}$.

In all cores sediment accumulation rates showed a relative increase through time, from 1890 to present (Figure 18). Although this increase was not necessarily linear throughout the entire core, and even showed a decrease (LM-28, LM-31, LM-50) in the upper sediments, the increase appears to be drastic post-1960 (LM-28, LM-32, LM-50). Sediment accumulation rates were additionally used to calculate nutrient (TC,TN) accumulation rates through time (Table A-6). Not surprisingly, sediment accumulation rates showed similar historical trends for nutrient accumulation (Figure 19). Cores LM06, LM-32, and LM-50 all showed rather drastic increases in TC and TN accumulation through time, with a record accumulation occurring in the mid-1990's in all cores.

\subsection{Cesium-137 $\left({ }^{137} \mathrm{Cs}\right)$}

Similar to the cores analyzed for ${ }^{210} \mathrm{~Pb}$, which lacked sufficient background values used for calculating age and sedimentation rate, none of the three cores analyzed for ${ }^{137} \mathrm{Cs}$ showed a clear peak (Figure 20), likely a consequence of coarse sample resolution and possibly mixing by wave action and/or continued inputs of ${ }^{137} \mathrm{Cs}$ from the watershed or littoral areas of the lake. Nonetheless, all three cores show a clear demarcation between intervals with ${ }^{137} \mathrm{Cs}$ and those at depth without.

Assuming the first appearance of ${ }^{137} \mathrm{Cs}$ corresponds to the commencement of global ${ }^{137} \mathrm{Cs}$ fallout in 1954 , the cesium profiles fit quite well with the ${ }^{210} \mathrm{~Pb}$ chronologies in all cases. The ${ }^{137} \mathrm{Cs}$ results thus confirm that recent $\left({ }^{137} \mathrm{Cs}\right.$-bearing) sediments are present in the upper sections of these cores (the cores have not been truncated by erosion 

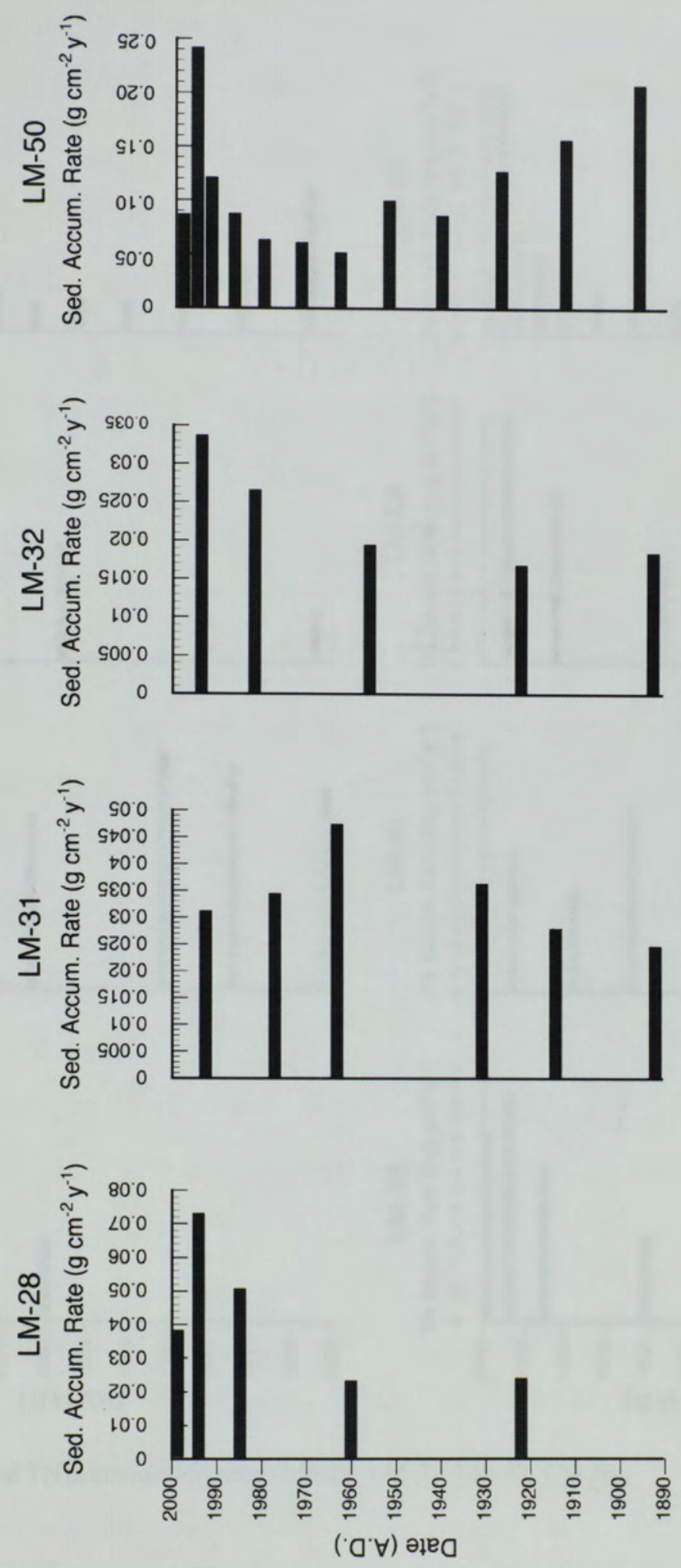

FIGURE $18{ }^{210} \mathrm{~Pb}$ calculated sediment accumulation rates according to $\mathrm{cf}: \mathrm{cs}$ model (LM-28, LM-31, LM32, LM-50). 

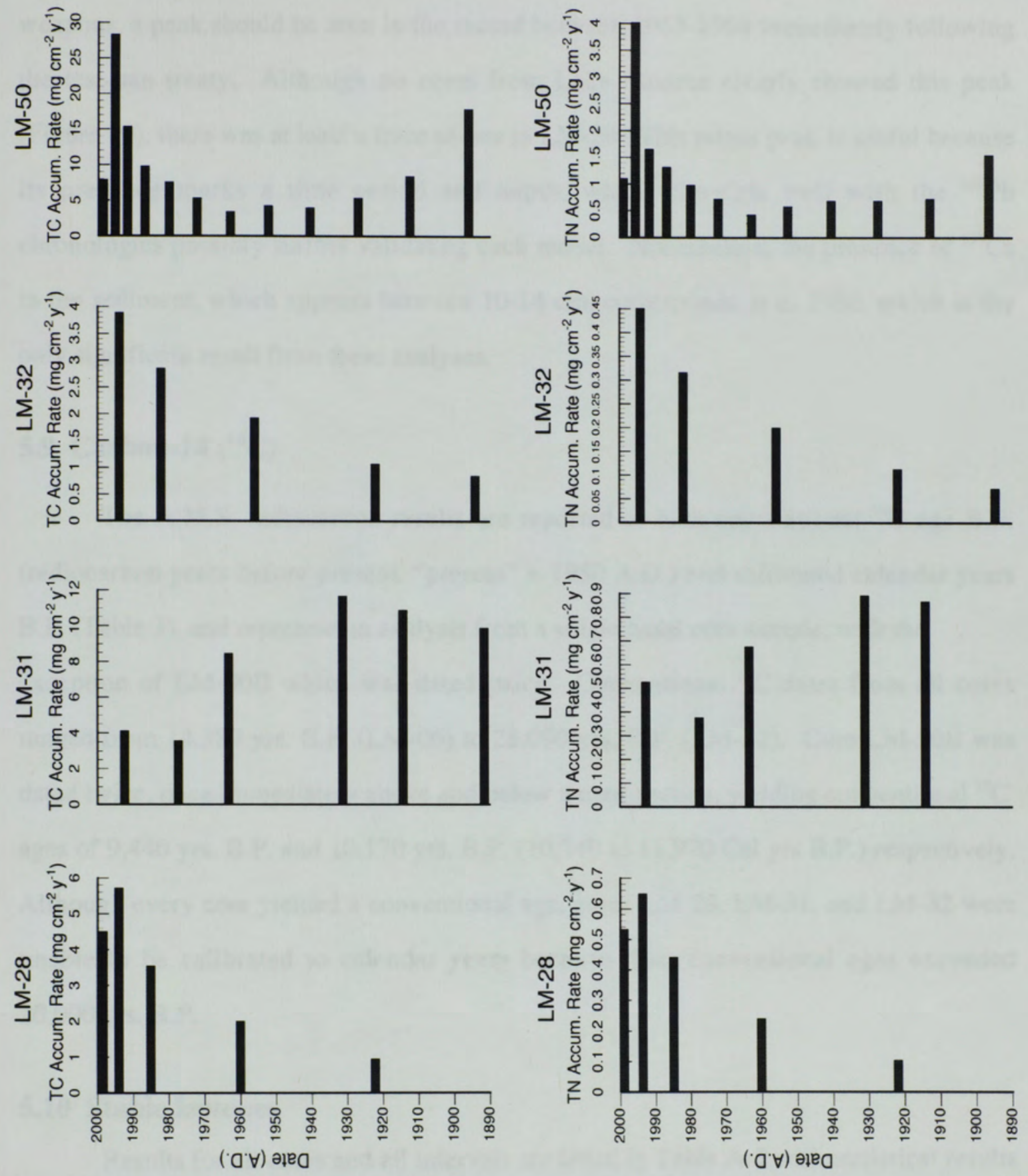

FIGURE 19 TC and TN accumulation rates (LM-28, LM-31, LM-32, LM-50). 
or coring problems). With, due to the atmospheric testing of high-yield thermonuclear weapons, a peak should be seen in the record between 1963-1964 immediately following the test-ban treaty. Although no cores from Lake Monroe clearly showed this peak (Figure 20), there was at least a trace of one in LM-28. This minor peak is useful because its presence marks a time period and depth, which correlate well with the ${ }^{210} \mathrm{~Pb}$ chronologies possibly further validating each model. Nonetheless, the presence of ${ }^{137} \mathrm{Cs}$ in the sediment, which appears between 10-14 cm, corresponds to c. 1950, which is the only significant result from these analyses.

\subsection{Carbon-14 $\left({ }^{14} \mathrm{C}\right)$}

The A.M.S. radiocarbon results are reported as both conventional ${ }^{14} \mathrm{C}$ age B.P. (radiocarbon years before present, "present" = 1950 A.D.) and calibrated calendar years B.P. (Table 3), and represent an analysis from a single basal core sample, with the exception of LM-50B which was dated twice. Conventional ${ }^{14} \mathrm{C}$ dates from all cores ranged from 14,380 yrs. B.P. (LM-06) to 28,090 yrs. B.P. (LM-32). Core LM-50B was dated twice, once immediately above and below a marl section, yielding conventional ${ }^{14} \mathrm{C}$ ages of 9,440 yrs. B.P. and 10,170 yrs. B.P. (10,740 to 11,970 Cal yrs B.P.) respectively. Although every core yielded a conventional age, cores LM-28, LM-31, and LM-32 were unable to be calibrated to calendar years because their conventional ages exceeded 20,000 yrs. B.P.

\subsection{Stable Isotopes}

Results for all cores and all intervals are listed in Table A-8 with statistical results listed in Tables 4 and 5. A relative ${ }^{13} \mathrm{C}$ enrichment trend is seen in all cores (see Figure $14,15,16)$, particularly following the turn of the century, with the most negative values occurring below $30 \mathrm{~cm}$. A linear increase in ${ }^{15} \mathrm{~N}$ is seen only in core LM-06 while the 


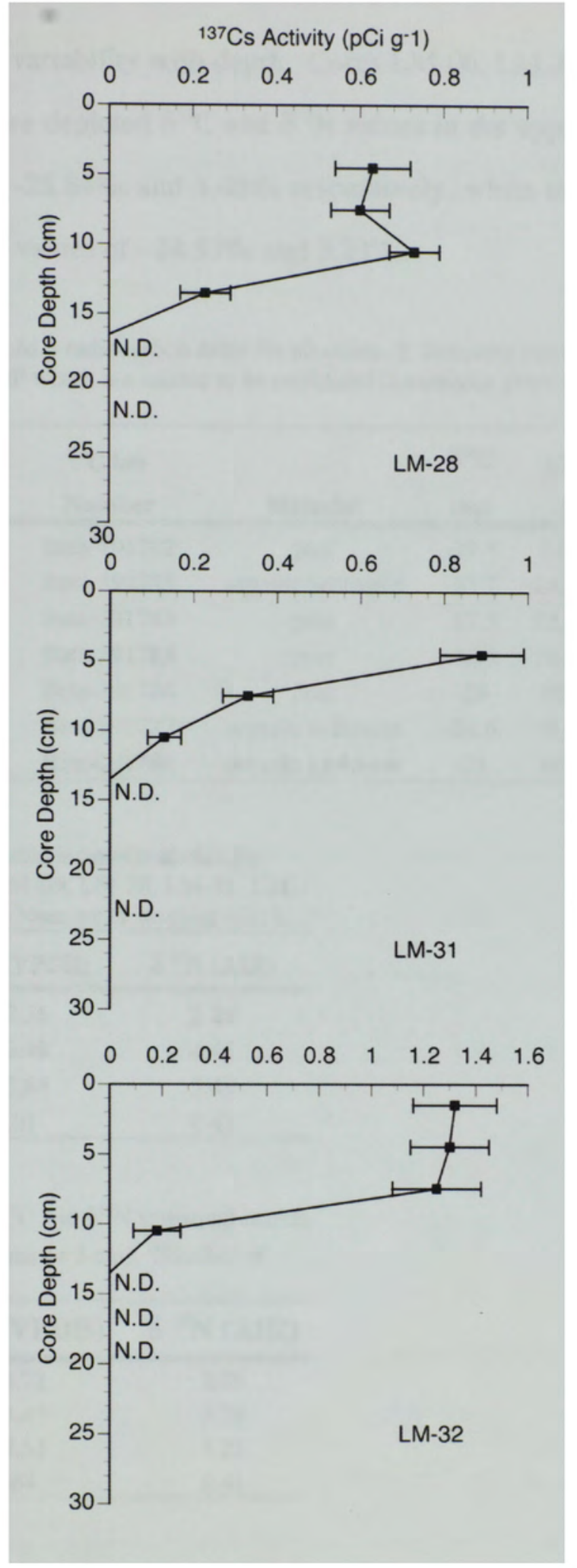

FIGURE 20 Total ${ }^{137} \mathrm{Cs}$ activity (LM-28, LM-31, LM-32). 
remaining cores show variability with depth. Cores LM-06, LM-28, LM-31, LM-32, and LM-45, all shift to more depleted $\delta^{13} \mathrm{C}$ and $\delta^{15} \mathrm{~N}$ values in the upper $6 \mathrm{~cm}$. Mean values for $\delta^{13} \mathrm{C}$ and $\delta^{15} \mathrm{~N}$ are $-25.84 \%$ and $3.45 \%$ respectively, while the surface values show slightly more enriched values of $-24.53 \%$ and $3.23 \%$.

TABLE 3 Lake Monroe A.M.S radiocarbon dates for all cores. $\ddagger$ indicates conventional ${ }^{14} \mathrm{C}$ age exceeding 20,000 yrs. BP which are unable to be calibrated to calendar years B.P.

\begin{tabular}{ccccccc}
\hline Core & $\begin{array}{c}\text { Depth in } \\
\text { Core }(\mathbf{c m})\end{array}$ & $\begin{array}{c}{ }^{14} \mathbf{C} \text { lab } \\
\text { Number }\end{array}$ & Material & $\begin{array}{c}\boldsymbol{\delta}^{13} \mathbf{C} \\
(\%)\end{array}$ & $\begin{array}{c}\text { Conv. }{ }^{14} \mathbf{C} \\
\text { Age BP }\end{array}$ & $\begin{array}{c}\text { Cal yrs } \\
\text { BP }\end{array}$ \\
\hline \hline LM-06 & $54-57$ & Beta-191782 & peat & -27.5 & $14,380 \pm 50$ & $17,225 \pm 355$ \\
LM-28 & $39-42$ & Beta-191783 & organic sediment & -25.7 & $24,390 \pm 160$ & $\ddagger$ \\
LM-31 & $51-54$ & Beta-191784 & peat & -27.3 & $22,390 \pm 130$ & $\ddagger$ \\
LM-42 & $66-69$ & Beta-191785 & peat & -26.3 & $28,090 \pm 250$ & $\ddagger$ \\
LM-45 & $36-39$ & Beta-191786 & peat & -26 & $18,360 \pm 80$ & $21,820 \pm 520$ \\
LM-50B & $19-21$ & Beta-191787 & organic sediment & -24.6 & $9,440 \pm 40$ & $10,740 \pm 90$ \\
LM-50B & $47-49$ & Beta-191788 & organic sediment & -24 & $10,170 \pm 40$ & $11,970 \pm 330$ \\
\hline
\end{tabular}

TABLE 4 Lake Monroe stable isotope statistics for selected six cores (LM-06, LM-28, LM-31, LM32, LM-45, LM-50). Number of samples $=111$.

\begin{tabular}{ccc}
\hline Statistic & $\boldsymbol{\delta}^{13} \mathbf{C}(\mathbf{V P D B})$ & $\boldsymbol{\delta}^{15} \mathbf{N}(\mathbf{A I R})$ \\
\hline \hline Min & -27.36 & 2.29 \\
Max & -23.49 & 4.45 \\
Mean & -25.84 & 3.45 \\
Stdev & 1.01 & 0.47 \\
\hline
\end{tabular}

TABLE 5 Lake Monroe $\delta^{13} \mathrm{C}$ and $\delta^{15} \mathrm{~N}$ statistical results for surface sediments $(<3 \mathrm{~cm})$. Number of samples $=20$.

\begin{tabular}{ccc}
\hline Statistic & $\boldsymbol{\delta}^{13} \mathbf{C}(\mathbf{V P D B})$ & $\boldsymbol{\delta}^{15} \mathbf{N}(\mathbf{A I R})$ \\
\hline \hline Min & -25.72 & 2.08 \\
Max & -23.45 & 3.78 \\
Mean & -24.53 & 3.23 \\
Stdev & 0.64 & 0.41 \\
\hline
\end{tabular}




\section{DISCUSSION}

The surface sediments represent the most recent sediments deposited in Lake Monroe. The presence of these sediments is indicative of the contemporary biological and sedimentological regime in place at Lake Monroe and of most interest to this study. The most recent, or upper-most consolidated sediment type recovered in 18 of 20 cores was gyttja.

Gyttja, also referred to as copropel, was earlier described as fine-grained dark brown organic sediment. Gyttja is the most recent sediment being deposited at Lake Monroe, and is distributed with no discernible pattern. Gyttja forms under oxygenated conditions and may be composed partially or entirely of fecal material having been transformed by chironomids or other benthos (Cohen, 2003). Mud Lake, a shallow (>1 m) eutrophic lake located in Marion Co. in central Florida, has a rich organic copropellic gyttja composed almost entirely of fecal pellets from Chironomus (chironomid) larvae with diets restricted to blue-green algae (Cole, 1994; Ioviono and Bradley, 1969). This is fitting, considering that gyttja is the common lacustrine sediment of eutrophy (Cohen, 2003), and that eutrophic lakes often are characterized by the occurrence and abundance of algal blooms.

Furthermore, experiments by Ioviono and Bradley (1969) on laboratory-reared midges from Mud Lake, FL (Marion Co.) show that the number of fecal pellets produced and sedimented, increased with the concentration of algal cells available for consumption. The authors found that larvae which were fed blue-green algae produced the greatest amount of coherent fecal material. Glyptotendipes paripes (G. paripes), a major pestiferous chironomid midge species in Florida, reproduce and emerge in large numbers from suburban lakes like Lake Monroe (Frouz et al., 2004), even resulting in economic losses due to nuisance related problems. The presence of these midges 
indicates a suitable environment, characterized by the appropriate algal composition, and may lead to an abundance of fine-grained $(<25 \mathrm{~mm})$ sedimented fecal material. The production of fecal pellets corresponds with chironomid larval abundance, their feeding activity and food quality (Frouz et al., 2004). The relative thickness and position of the gyttja layer in the sediment record may mark the extent and onset of eutrophy in Lake Monroe forced by the extensive feeding and excreting of algal material by chironomid larvae.

The peats from Lake Monroe represent the oldest sediments recovered, and therefore hold paleoecological significance for the lake basin. Peats form in a variety of conditions, both fresh and marine, and in temperate and tropical regions. Peats from temperate regions generally form in vegetated, nutrient poor, acidic water logged areas, referred to as bogs, whereas the freshwater peats forming in subtropical Florida (Everglades) are in fact much different. Analyses of $\mathrm{pH}$, performed on bulk sediments show that Lake Monroe peats are not acidic (Anderson, 2005). The average $\mathrm{pH}$ value for peat in all cores was 7.4, with a maximum and minimum value of 8.3 and 6.6 respectively. This suggests that the peats, although formed in a wetland environment, did not form in an acidic bog-type system but rather in system similar to modern day freshwater Everglades.

Peat types representing 12 different depositional environments have been identified in Florida Bay through the investigation of over 600 sites (Davies and Cohen, 1989). Of the 12 peats identified, 7 were of freshwater origin and occurred at the bases of 134 cores, which contained peat. These findings suggest that Florida Bay at one time was an extension of the Everglades, only to be later inundated by rising seas. This scenario may be similar to the evolution of the Lake Monroe peats. Lower base level during the late Pleistocene would allow freshwater peats to form in the shallow river and 


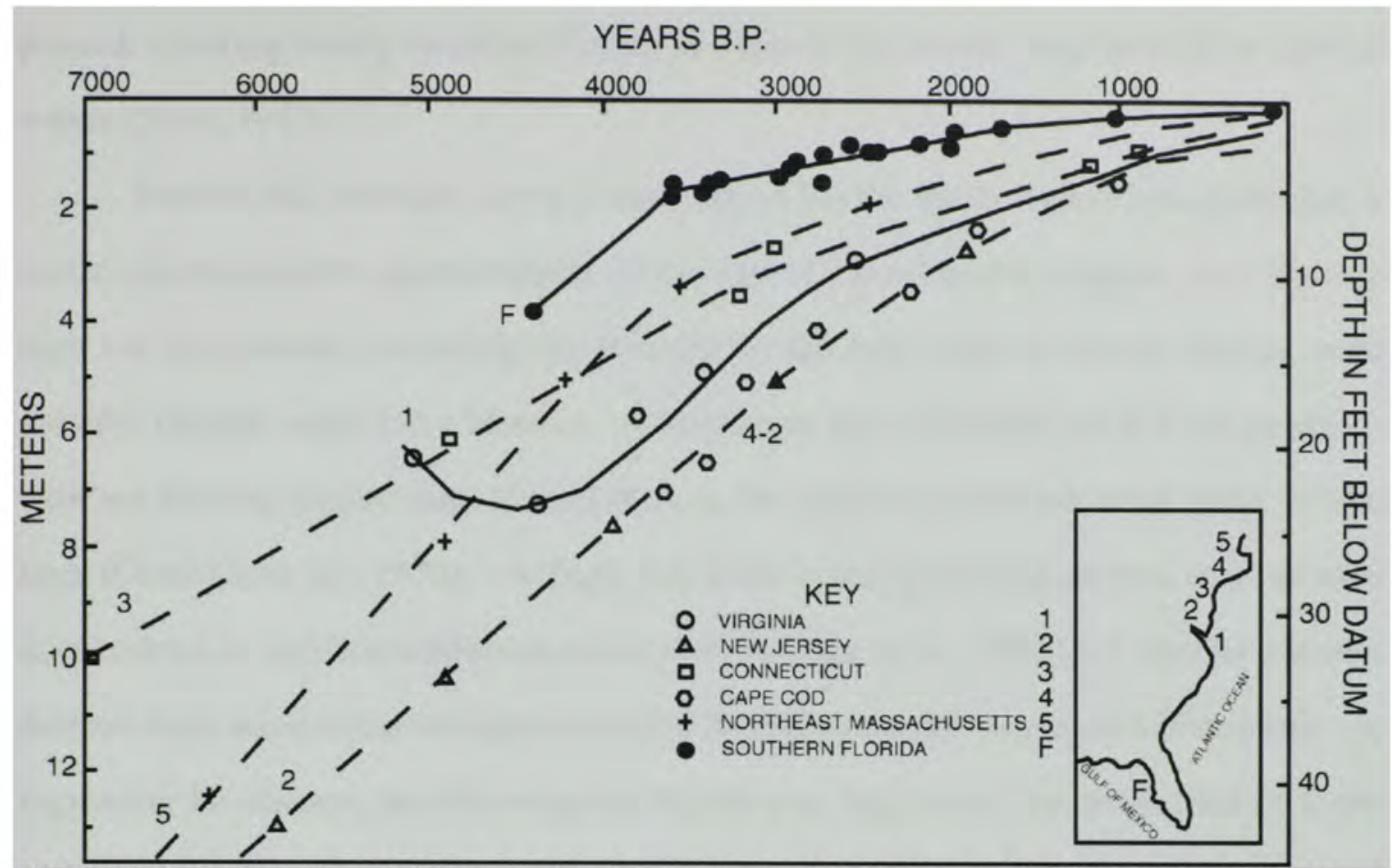

FIGURE 21 Overlay of six Holocene sea level curves for the Atlantic coast of the U.S. (after Scholl and Stuiver, 1967),

lake basins of the St. Johns. A rapid increase in sea level in the early Holocene (Figure 21) would have raised water levels in the St. Johns River, flooded the peats forming in shallow water (Davis, 1946), and altered the sedimentological regime within Lake Monroe leading to the deposition of more recent sediments like gyttja.

Few radiocarbon dates are available for Lake Monroe, but the basal peat samples which were dated, range in age from $14,380 \pm 50$ B.P. (LM-06) to $28,090 \pm 250$ (LM-32). These dates are currently the oldest documented for the St. Johns River valley. The age range of these basal sediments may indicate the accumulation and subsequent flooding of sediments associated with the ancient St. Johns River valley, beginning as early as the late Pleistocene. Unlike sea-level transgressions during the Pliocene which inundated the entire Florida platform, Pleistocene transgressions did not rise higher than $20 \mathrm{~m}$ above 
present, covering mostly southern Florida and low-lying coastal areas in shallow marine waters (Scott, 1997).

Radium and thorium isotopic analyses of fossils shells from Cape Kennedy, a barrier island complex approximately $25 \mathrm{~km}$ east of Lake Monroe, suggest three distinct high sea level stands (including the Recent) for the east coast of central Florida, with possible impacts upon Lake Monroe. A Sangamon age ( 130,000 yrs B.P.) high stand, with sea level no higher than $10 \mathrm{~m} \pm 4 \mathrm{~m}$, is the oldest reported sea level stand for the area (Osmond et al., 1970). A high sea level stand occurring at this time is also documented in uplifted Caribbean coral reefs (Dodge et al., 1983). A second but less defined high stand occurred approximately 30,000 years B.P in the mid-Wisconsin. A regressing Pleistocene sea following the 30,000 year high stand was proceeded by a dry early-Holocene environment, inferred not only from pollen data but from charcoal (indicating dry fuel) deposits in lake deposits (Watts and Hansen, 1988) from central Florida. Levels rose quickly in the Holocene beginning around 8,000 yrs B.P., only to slow around 4,000 yrs B.P.

Groundwater and surface water approached modern day levels as early as the mid-Holocene (Figure 21). Lake sediment studies in Florida show that many lake basins were dry until about 8,000 years ago (not including Lakes Annie and Tulane) as a result of low sea level and increased infiltration (Filley et al., 2001; Watts, 1975). Radiocarbon dated pollen recovered from Lake Annie, a deep solution lake in south-central Florida $\left(27^{\circ} 12^{\prime} \mathrm{N}, 81^{\circ} 25^{\prime} \mathrm{W}\right)$, indicate three distinct stratigraphic zones, each the result of a different climatic regime in central Florida. Zone 3 (37,000 $\pm 3,200$ B.P.), marked by dune vegetation and a lack of pine species, indicates a much drier climate and lack of sufficient soil moisture. Zone 2 and 1 (13,010 \pm 165 B.P. and 4,715 \pm 95 B.P.) show evidence of increased precipitation and soil moisture. Increased percentages of pollen from bald cypress and long-leaf pine replaced dry oak species around 2,630 \pm 85 B.P. 
suggesting the flourishment of cypress swamps at this time (Watts, 1975). These palynological records show that in south-central Florida, before 15,000 B.P., the climate was much drier than present, and as early as 5,000 yrs. B.P. modern vegetation and peatland communities were being established (Watts and Hansen, 1988).

The presence of peat layers at Lake Monroe suggests a wetland once existed before lake impoundment, possibly as old as 130,000 yrs B.P. This wetland was most likely a standing body of brackish water (White, 1970) that formed during the Pleistocene, as transgressing and regressing seas shaped the Florida platform (Scott, 1997) (see section 3.3). As sea level dropped, so to would the water levels in the ancient river valley, only to be filled later by a possible high stand at 30,000 yrs B.P. This may account for the presence of diatoms indicative of modern-day Everglades sloughs and saline environments at depths greater than $30 \mathrm{~cm}$ in Lake Monroe cores (Anderson, 2005).

More evidence of Lake Monroe as a part of a larger peat-forming wetland, is found in the shape of the lake itself. Unlike other fairly circular lakes in Florida (Apopka, Kissimmee, Cypress), which formed further inland consequent to solution and are grouped together, Lake Monroe is elongate in the direction (east-west) of St. Johns River flow. This suggests that a larger, broader wetland once existed in place of the river, and has since been differentially infilled with sediment and vegetation. The headwaters of the St. Johns can be found in a broad swampy valley, while downstream at the rivers mouth, still remains an active estuary. In between these two reaches lies the river itself, along with its chain of lakes. It is the unfilled remains of the ancient wetland that have become modern-day river and its lakes.

Given sufficient time, lakes will become infilled with sediment, later evolving into shallow marshes in which emergent vegetation can take growth. It is the nature of peat-forming environments to be oligotrophic and nutrient starved. Nutrient analyses of 
$\mathrm{C}, \mathrm{N}$, and $\mathrm{P}$ (see later discussion) of these peats show the lowest values of $\mathrm{P}\left(\mathrm{ug} \mathrm{g}^{-1} \mathrm{dw}\right.$ ) at depth, yet highest $\mathrm{C} / \mathrm{N}$ values, suggesting possible emergent macrophyte dominance in a P-limited environment. This relationship is quite unlike the modern system in which $\mathrm{P}$ concentration increases are thought to have increased productivity by algae. Further coring, not in the lake, but rather in the floodplain, should see the recovery of peats that may have formed in the ancient wetland. A transect of cores extended into the floodplain could help reveal the breadth of this wetland.

Additional radiocarbon dating of macrofossils is necessary to truly establish an accurate historical and high resolution age model for the peat-forming sediments, not unlike studies of Florida lakes Tulane and Annie (Grimm et al., 1993; Watts, 1975). The ${ }^{14} \mathrm{C}$ dates may have been affected by the sedimentation of older particulate $\mathrm{OC}$ from outside the basin. Sediments which have been transported into the lake from other basins via the St. Johns River may be the cause for these extremely old dates. Also, fine-grained sediments, prone to re-suspension within the Lake Monroe basin, could have caused dating discrepancies as these particles can easily become re-suspended and re-sedimented through time by turbulent wind-induced waves. Macrofossils (leaf material, wood, roots), which likely would be deposited in place, would be ideal for dating and establishing a better chronology. A total of 5 radiocarbon dates is not enough to establish these results as truly significant, though the possibilities for further dating and confirmation of these results are exciting.

The sands/clays/marls, found in 9 of the 20 cores, separate the gyttja from the bottom-most peat layers in 5 of these 9 cores, and represent a much different time or transitional state in the lakes history. The fine brown sands, which were not analyzed, represent terrigenous material, most likely entering the basin through overland runoff or river discharge. Spatial analyses of the core locations showing sand (not shown), revealed no significant spatial distribution, but cores LM-07, LM-39, LM-57, which had 
substantial $(>10 \mathrm{~cm})$ sand deposits in the upper portions of the cores, are all located on the periphery of the lake, and likely received higher amounts of terrestrial input then the other sites without sand layers. In the case of LM-07 and LM-57 specifically, which are located at the outflow and inflow respectively, sediment transport could have been accelerated by the construction of roads over both areas. Most likely, sand at site LM-07 signifies deposition of sediment as the St. Johns River enters the larger Lake Monroe, depositing entrained sediments.

The presence of marls (8 sites), which were dated to 11,970 Cal yrs. B.P. in core LM-50B, indicate the onset of shallow water Holocene sedimentation at Lake Monroe at that time. Contributions from freshwater gastropods and bivalves can be important to the formation of this sediment, as whole and broken shell fragments, were found in all 20 cores typically overlying peat. Marls were not found at depth, in any cores except LM50B. The $\mathrm{CO}_{2}$, derived from the decay of $\mathrm{OM}$, dissolves marl and hinders deposition. The decay of peat material, during low water times may be why no marls are found with peats. Also, increased photosynthesis of benthic and planktonic algae can precipitate $\mathrm{CaCO}_{2}$ (Cole, 1994). The inferred abundance of these algae from the $\mathrm{C}$ and $\mathrm{N}$ record, may suggest the role of blue-greens in forming marls.

The only unconsolidated sediment recovered throughout the study period was floc. The average thickness of this layer was $7.6 \mathrm{~cm}$, and it is likely increasing. Other eutrophic lakes, most notably Lake Apopka, contain a similar floc layer which has increased in thickness on average of $1 \mathrm{~cm} / \mathrm{yr}$ (Bachmann et al., 2005). Several theories concerning the origin and role of the floc layer at Lake Apopka to the lakes prolonged eutrophic state are documented (Bachmann et al., 2005). One theory (Schelske, 1997) suggests the presence of the floc layer as the accumulation of dead algal remains, while the other (Bachmann et al., 2005) suggests wave-induced liquefaction of underlying consolidated sediments to be the cause. Theories over the formation of this layer differ, 
but the presence of the fluid mud remains to have significant effects on lake water quality. Not only does this layer contribute to the turbid water quality, but also it prevents the rooting of submersed macrophytes and serves as an internal source of nutrients.

The sediment survey from the short cores, and the sediment stratigraphy from the long cores, offer some interesting questions and possible answers as to why those sediment types are present and in a particular order. Floc, gyttja, sands, clays, and freshwater marls are not uncommon lake sediments, yet the presence of the thick peat layer suggests a drastically different sediment-forming environment than the one present at Lake Monroe and worth further investigation.

Applying the dating models to the sediment record implies that Lake Monroe was in a eutrophic state, possibly for the first time, as early as 100 years ago. Radiometric dating $\left({ }^{137} \mathrm{Cs},{ }^{210} \mathrm{~Pb}\right)$ provided the framework for interpreting both the sedimentological and geochemical data. The ${ }^{137} \mathrm{Cs}$ and ${ }^{210} \mathrm{~Pb}$ chronologies, which were in good agreement, provided a solid chronological framework for the deposition of sediments. Although these records appear to support each other, re-suspension, diagenesis, and mixing of sediments, coupled with the outflow of fallout radionuclides, will provide only generalized rates of sedimentation over the last century (Colman et al., 2004). The interpretation of recent sediment ages and accumulation rates will be limited to dates post-1900, because old, or low activity samples, yield large error estimates. Accordingly, it is only during this short period (post-settlement) which is of concern to the study.

In comparison to other eutrophic lakes in Florida, these sediment accumulation rates are consistently lower than expected. Orange Lake, located in north-central Florida $\left(29^{\circ} 27^{\prime} 20^{\prime \prime} \mathrm{N}, 82^{\circ} 10^{\prime} 20^{\prime \prime} \mathrm{W}\right)$, is of similar size and depth to Lake Monroe, yet has sedimentation rates $\left(1.73 \mathrm{~g} \mathrm{~cm}^{-2} \mathrm{yr}^{-1}\right)$ several orders of magnitude higher (Brenner et al., 1999). Lake Monroe may owe its relatively low sedimentation rates to outflow through 
the St. Johns Rivers and continual re-suspension of sediments upon its shallow bottom by wind-induced waves. The fact that Orange Lake is eutrophic and highly productive seems not to hold as dominant a control over sedimentation as does flushing rate. Lake Monroe and Lake Harney, both within the MSJRB and connected by the St. Johns River, have mean annual streamflows $\left(\mathrm{ft}^{3} / \mathrm{sec}\right)$ of 2,243 and 1,932 respectively for the period 1982-2003. Conversely, Orange Lake which is drained by the relatively small Orange Creek in Marion Co., Florida, has a mean annual streamflow $\left(\mathrm{ft}^{3} / \mathrm{sec}\right)$ of 127 for the period 1943-2003.

Within Lake Monroe's watershed and throughout the world, industrialization increased exponentially during this time ( $>1900)$, accompanied by land use changes with a strong influence on the sedimentological and chemical behavior of many lake basins (Alvisi and Frignani, 1996). During this brief period in the history of Lake Monroe, the ${ }^{210} \mathrm{~Pb}$ calculated sediment accumulation rates were low, but showed an increase with time (except LM-31). This increase may be attributed to the natural evolution and sedimentation within a productive lake in the 20th Century, or these results may point to increased sedimentation caused by land use changes and increased nutrient loading within the watershed associated with land settlement.

The MAR's of nutrients in the sediments, although fairly low at the turn of the century, steadily increased throughout the historical period with only a recent decline in the last 10 years observed in LM-31 and LM-50. The historical steady increase is likely the result of land use changes and nutrient supply within the basin. These increases in sediment accumulation are observed in other sections of the St. Johns River Watershed Basin. Brenner et al. (2001) report an historical increase in both sediment and nutrient $(C, N, P)$ accumulation over the past century at Blue Cypress Lake in the USJRB. Recent sediment accumulation rates $\left(\mathrm{g} \mathrm{cm}^{-2} \mathrm{yr}\right)$ were consistently higher than rates deeper in the profiles at Blue Cypress Lake. Values approaching zero (0.01) were observed in 
sediments ${ }^{210} \mathrm{~Pb}$-dated to 1813 , with maximum values of 0.06 occurring in 1991 (Brenner et al., 2001).

The recent decline in sediment accumulation observed at Lake Monroe may be attributed to possible nutrient abatement measures applied within the watershed, thus decreasing productivity, or it may indicate a heterotrophic system. A heterotrophic lake is one in which community respiration of OM exceeds production, and is fueled by either an external or internal supply of excess carbon (Bachmann et al., 2000). In a lake such as Lake Monroe, which the sediment record suggests was once macrophyte dominated, the source of excess carbon may be the remains of macrophytes deposited in the sediments prior to the switch to algal production.

The $\mathrm{C}$ and $\mathrm{N}$ analysis of the sediments provided some interesting insight into the lake's physiochemical nature. TOC values increased with depth in all cores except LM28. TOC concentration is a bulk value that represents the fraction of OM that escaped remineralization during sedimentation (Meyers, 2003), suggesting higher proportions of OM and delivery of organic carbon in the older sediments of Lake Monroe. Consequently, the highest TOC values were in peat sediments. For all cores, except LM06 , the TOC and TN curves parallel each other, suggesting that $\mathrm{C}$ and $\mathrm{N}$ are bound primarily in the organic sediment fraction (Brenner et al., 1999b).

TOC and TC are important indicators of OM. Since sedimented OM contains approximately $50 \%$ carbon, the concentration of $\mathrm{OM}$ in the sediment is equal to twice the calculated TOC value (Meyers, 2003). Additionally, TIC (bio-induced calcite) production and accumulation in sediment is a strong indicator of primary production (Jinglu et al., 2004), which can also be attributed to historical nutrient loading (Hodell and Schelske, 1998; Schelske and Hodell, 1991) and possible eutrophication.

Stratigraphic trends (increases vs. decreases) in $\mathrm{C}$ and $\mathrm{N}$ accumulation within the sediment may provide evidence for historical production, and may also reflect 
proportions of sedimented terrestrial and algal carbon in OM (Kaushal and Binford, 1999; Meyers and Lallier-Verges, 1999; Talbot and Laerdal, 2000). Notable increases in both $\mathrm{C}$ and $\mathrm{N}$ accumulation can be attributed to increases in productivity and rapid settling of OM (Teranes et al., 1999). Vascular plants, which have greater proportions of cellulose to protein, generally exhibit $\mathrm{C}: \mathrm{N}$ ratios greater than 20 , whereas phytoplankton, which have greater proportions of protein to cellulose, have lower values between 4-10 (McFadden et al., 2004; Meyers and Lallier-Verges, 1999). Possible reasons for different observed C:N ratios in the sediment could be the availability and proportions of nutrients $(\mathrm{C}, \mathrm{H}, \mathrm{N}, \mathrm{O}, \mathrm{P})$ in natural waters, which would ultimately affect the production of OM (Lehmann et al., 2004; Meyers, 1997).

The $\mathrm{C} / \mathrm{N}$ ratios vary with depth in all cores, but high $\mathrm{C} / \mathrm{N}$ values are consistently observed in the basal sediments. Cores LM-32 and LM-45 show the least variability with depth, as C/N values increased, while cores LM-06, LM-28, and LM-50 displayed the greatest variability. Consequently, in core LM-50, which has the longest complete age model, $\mathrm{C} / \mathrm{N}$ values shift to more positive values around 1900 immediately following a negative shift in which values changed by 12 . Prior to this shift, core LM-50 displayed a high of 14 and a low of 2 . Following this shift, $\mathrm{C} / \mathrm{N}$ values increase for the remainder of the sediment record.

The higher $\mathrm{C} / \mathrm{N}$ ratios, observed in the basal portions of cores LM-31, LM-32, LM-45, and LM-50 indicate greater contributions of plant material with more structure, while the lower values, seen at depth in LM-06 and LM-28, reflect greater contributions of phytoplankton (Brenner et al., 1999a). Variability displayed in these cores, may reflect not only greater contributions of terrestrial material from land use changes, but also from littoral vegetation which may have proliferated during low lake stages only to be inundated upon a rise in water levels and later sedimented. 
The isotope record, when viewed as an indicator of productivity, fits well with the TC and TN stratigraphy. With carbon and nitrogen abundances increasing in the basin, the isotope records show relative enrichment through time, suggesting increased production and uptake, and depletion of the light isotope $\left({ }^{12} \mathrm{C},{ }^{14} \mathrm{~N}\right)$ pool. All cores show a relative enrichment trend in $\delta^{13} \mathrm{C}$ through time, with a slight negative excursion (LM06, LM-28, LM-31, LM-32) in the most recent sediments $(<6 \mathrm{~cm})$, suggesting possible reductions in nutrient levels and production. This shift may be the result of the diversion of excess nutrients from the basin by local municipalities, or a possible explanation may be the utilization of isotopically light $\mathrm{CO}_{2}\left(\delta^{13} \mathrm{C}_{\text {(fossil fuel) }}=-28 \%\right.$ ) (Peterson and Fry, 1987) caused by increased rates of fossil fuel combustion (Brenner et al., 1999).

$\delta^{13} \mathrm{C}$ shifts to more positive values, observed in the recent sediments $(<6 \mathrm{~cm})$ of cores LM-45 and LM-50, may also reflect a different source of carbon utilization. For instance, freshwater phytoplankton can produce relatively ${ }^{13} \mathrm{C}$-enriched biomass under $\mathrm{CO}_{2}$ limiting conditions (Filley et al., 2001; Meyers and Lallier-Verges, 1999). Cyanobacteria, a major producer of algal organic carbon in surface sediments of eutrophic lakes, which fix $\mathrm{CO}_{2(\text { aq })}$ in isotopic equilibrium with the atmosphere, have the ability to internally concentrate ${ }^{13} \mathrm{C}$-enriched $\mathrm{HCO}_{3} \cdot\left(\delta^{13} \mathrm{C}=1 \%\right.$ ) when rates of photosynthesis exceed $\mathrm{CO}_{2}\left(\delta^{13} \mathrm{C}=-7 \%\right)$ availability. Although rare and species dependent, situations occur where $\mathrm{HCO}_{3}{ }^{-}$is utilized during times of high photosynthetic uptake. In such cases, the $\delta^{13} \mathrm{C}$ values of algal $\mathrm{OM}$ can be as enriched as $-9 \%$ (Meyers and Lallier-Verges, 1999).

The $\delta^{15} \mathrm{~N}$ record in Lake Monroe displays more variability than the carbon isotope record but still may hold some major implications for historic production inferences. A stable isotope study of sediment and plankton isotope ratios by Gu et al. (1996), in 83 lakes, shows a relationship between $\delta^{15} \mathrm{~N}$ of plankton and increasing trophic gradients, from oligotrophic to eutrophy. $\delta^{15} \mathrm{~N}$ values within Lake Monroe range from $2.5 \%$ 
4.5\%o, with the most enriched values, as observed in cores LM-06, LM-32, LM-45, and LM-50, occurring post-settlement. Yet, the fixation of $\mathrm{N}_{2}$ directly from the atmosphere $\left(\delta^{15} \mathrm{~N}=0 \%\right.$ ) by algal species during widespread algal blooms, could account for the modern decrease in $\delta^{15} \mathrm{~N}$ values observed in cores LM-06, LM-28, LM-31, LM-32, and LM45. The shift of $\delta$-values towards 0 throughout the sediment record, could indicate times of eutrophy which were marked by algal blooms.

The ${ }^{13} \mathrm{C}$ isotopic values appear somewhat straightforward. The relative enrichment through time infers heightened productivity and increased eutrophication. When the isotope values are plotted together (Figure 22) a clear distinction between sediment types can be observed. Peats represent those values less than $-26 \%$, while gyttja's are greater than $-25 \%$. When considering the isotope effects associated with diffusion of $\mathrm{CO}_{2}$ into and out of the cell, and environmental factors such as water stress, the resulting natural range of $\delta^{13} \mathrm{C}$ values for bulk terrestrial $\mathrm{C}_{3}$ cellular organic matter is approximately $-23 \%$ to $-31 \%$, while freshwater phytoplankton having a larger range of $-10 \%$ o to $-47 \%$ (Filley et al., 2001). Nonetheless, gyttja represents the most recent sediment being deposited in a highly productive system, and should display higher or more enriched ${ }^{13} \mathrm{C}$ values.

$\mathrm{C} / \mathrm{N}$ ratios may be employed to differentiate between the proportions of terrestrial and algal carbon (Filley et al., 2001; Kaushal and Binford, 1999) contributing to the sediment and the resultant isotopic values. Plotting $\mathrm{C} / \mathrm{N}$ versus $\delta^{13} \mathrm{C}$ (Figure 23) is one method of viewing and interpreting the evolution and source of biomass in a lake (Meyers, 2001). Viewing the Lake Monroe data in this manner reveals that the isotopic signal and $\mathrm{C} / \mathrm{N}$ for the $\mathrm{OM}$ is clustered around algae. This suggests a greater contribution from planktonic algae coincident with increased productivity in a hypereutrophic lake. Yet, these values may also indicate an increased epiphytic load from the presence of macrophytes. Macrophytes provide habitat for the growth of epiphytic algae (Cole, 


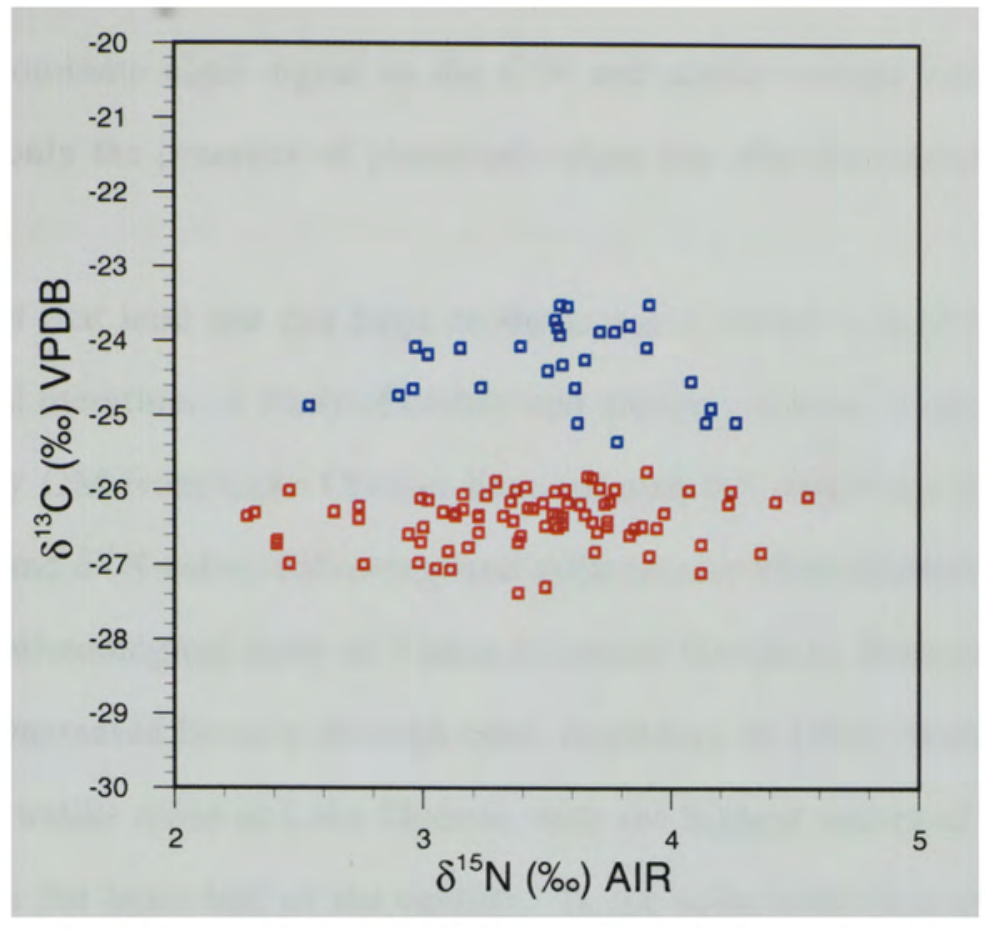

FIGURE $22 \delta^{15} \mathrm{~N}$ vs. $\delta^{13} \mathrm{C}$. Isotopic values are distinct for sediment type. Blue = gyttja. Red = peat.

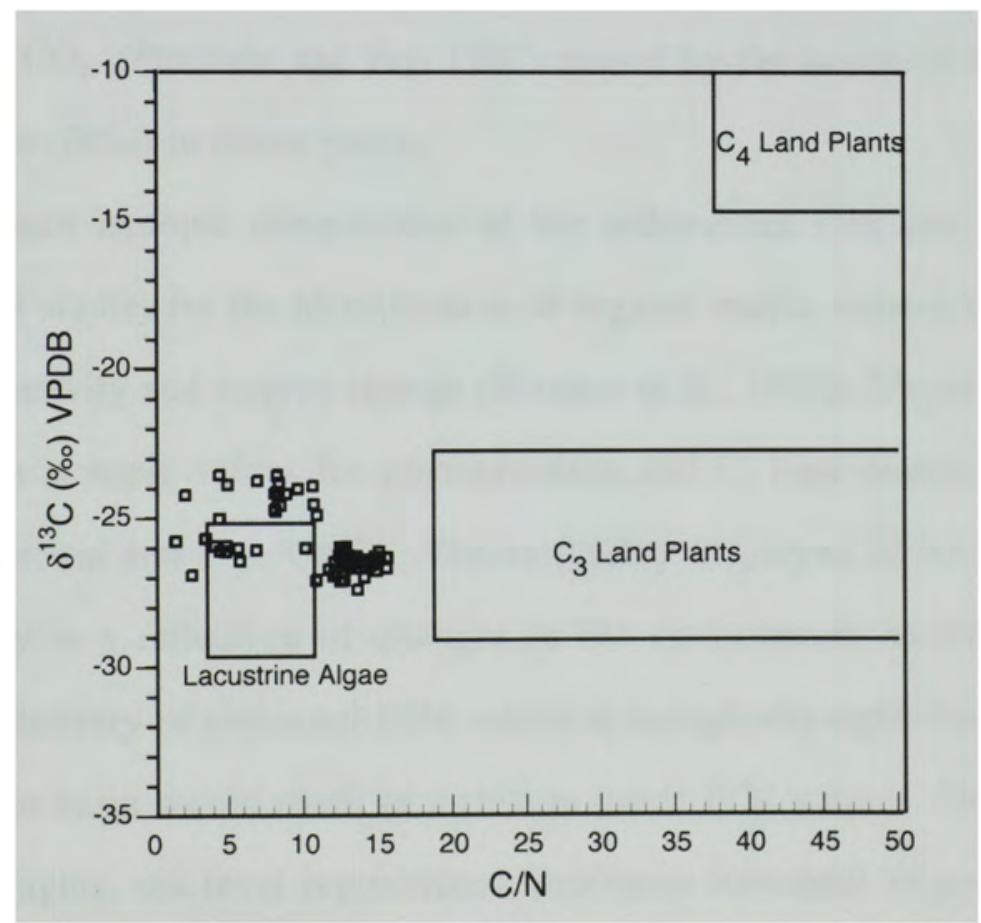

FIGURE 23 Cross plot of $\mathrm{C} / \mathrm{N}$ vs. $\delta^{13} \mathrm{C}$ depicting the evolution of biomass within Lake Monroe. Lake Monroe values plotted against Meyers plot. Values plotting in boxes represent predominate OM source (after Meyers, 2001). 
1994) so a predominate algal signal in the $\mathrm{C} / \mathrm{N}$ and stable isotope record must also account for not only the presence of planktonic algae but also macrophytes supporting epiphytes.

The effect that land use can have on the isotopic record is well documented in paleolimnological literature. A study of carbon and nitrogen isotopic composition of bulk sedimentary OM from Lake Ontario demonstrates this relationship with a linear increase in $\delta^{13} \mathrm{C}$ and $\delta^{15} \mathrm{~N}$ values following land settlement in 1840 (Hodell and Schelske, 1998). In a paleolimnological study of 4 lakes in central Florida by Brenner et al. (1999), the $\delta^{13} \mathrm{C}$ of OM increased linearly through time, beginning in 1900 . Both these studies show results not unlike those at Lake Monroe, with the highest values of both $\delta^{13} \mathrm{C}$ and $\delta^{15} \mathrm{~N}$ occurring in the latter half of the century. In the uppermost $(<6 \mathrm{~cm})$ portions of cores LM-06, LM-28, LM-31, and LM-32, there are slight declines in $\delta^{13} \mathrm{C}$ values. These declines may reflect reductions in nutrient levels and productivity, or the utilization of isotopically light $\mathrm{CO}_{2}$ (Peterson and Fry, 1987) caused by the increased combustion of fossil fuels $\left(\delta^{13} \mathrm{C}=-28 \%\right.$ ) in recent years.

The nitrogen isotopic composition of the sedimented OM can be applied to paleolimnological studies for the identification of organic matter sources to lakes and to reconstruct productivity and trophic change (Brenner et al., 1999a; Meyers, 2003). The range of nitrogen isotopic values for phytoplankton and $\mathrm{C}_{3}$ land plants is $1 \%$ to $8 \%$ respectively (Peterson and Fry, 1987). The variability displayed in the Lake Monroe cores most likely is a reflection of changes in the environment as well as nutrient utilization. The delivery of terrestrial DIN, which is isotopically light, from agricultural sources within the basin would result in a shift to lower $\delta^{15} \mathrm{~N}$ values. During low lake level stages (droughts, sea-level regressions), emergent terrestrial vegetation delivery may have increased while the algal contribution decreased in the Lake Monroe basin leading to a shift towards lower $\delta^{15} \mathrm{~N}$ values, such as those observed in some of the peat 
sediments. Also, as the environment became wetter through time inundating the peats as lake levels rose, fluvial inputs would increase, and so to would the availability of dissolved nitrate. This would lead to less discrimination by algae assimilating nitrogen (Meyers, 2003), which normally prefer the lighter ${ }^{14} \mathrm{~N}$ over ${ }^{15} \mathrm{~N}$.

Furthermore, shifts towards lower nitrogen isotope values have been observed in Florida lakes. Shifts to lower $\left(\delta^{15} \mathrm{~N}=-1 \%\right.$ to $3 \%$ ) values in sediments deposited since the early 1900's record increases in the contributions of nitrogen-fixing (atmospheric $\delta^{15} \mathrm{~N}=$ 0\%o) (Meyers and Lallier-Verges, 1999) cyanobacteria (Eilers et al., 2004) to OM production, as eutrophication of these lakes increased (Brenner et al., 1999a). Negative excursions in the Lake Monroe nitrogen isotope record could reflect an increase in nitrogen fixation by cyanobacteria, potentially explaining the relative depletion trends observed in cores LM-28, LM-31, LM-32, and LM-50.

Land use changes, mainly agricultural, that have taken place within the basin and throughout the St. Johns River, may also be the cause of lower isotope values. Additional chemical and biological data for Lake Monroe, not shown in this report, were taken from a report by Anderson et al. (2005). Phosphorus concentrations in lakes, mentioned earlier as an important limiting nutrient vital to productivity, was analyzed in all cores. Results show that phosphorous content generally declined with depth (Figure 24), especially throughout the gyttja layers. A decrease in P concentration with depth is also observed at Blue Cypress Lake in the USJRB suggesting similar nutrient dynamics downstream. High $\mathrm{P}$ concentrations in recent sediments may reflect either the presence of P-rich benthic algae or increased P loading through time (Brenner et al., 2001).

Lake Monroe peat sediments averaged the lowest concentrations of P, while SCM and gyttja averaged higher concentrations. Recent models of nutrient enrichment in shallow lakes show that macrophytes dominate when P loading is low (Kenney et al., 2002) and phytoplankton dominate when P loading increases (Figure 25). Here, nutrient 

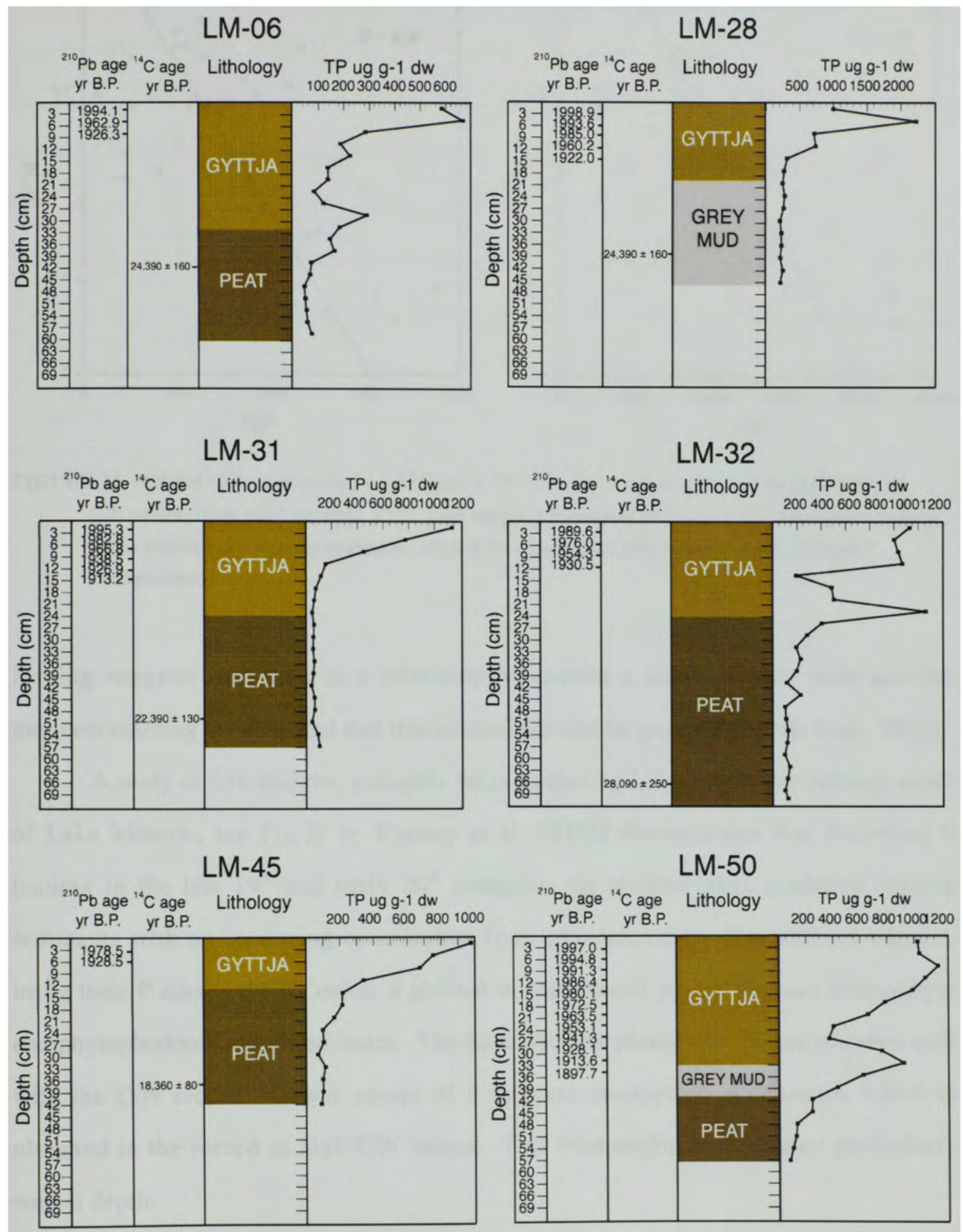

FIGURE 24 TP values plotted with depth. Radiometric dates and lithology shown for reference. Phosphorus data from Anderson et al. (2005). 


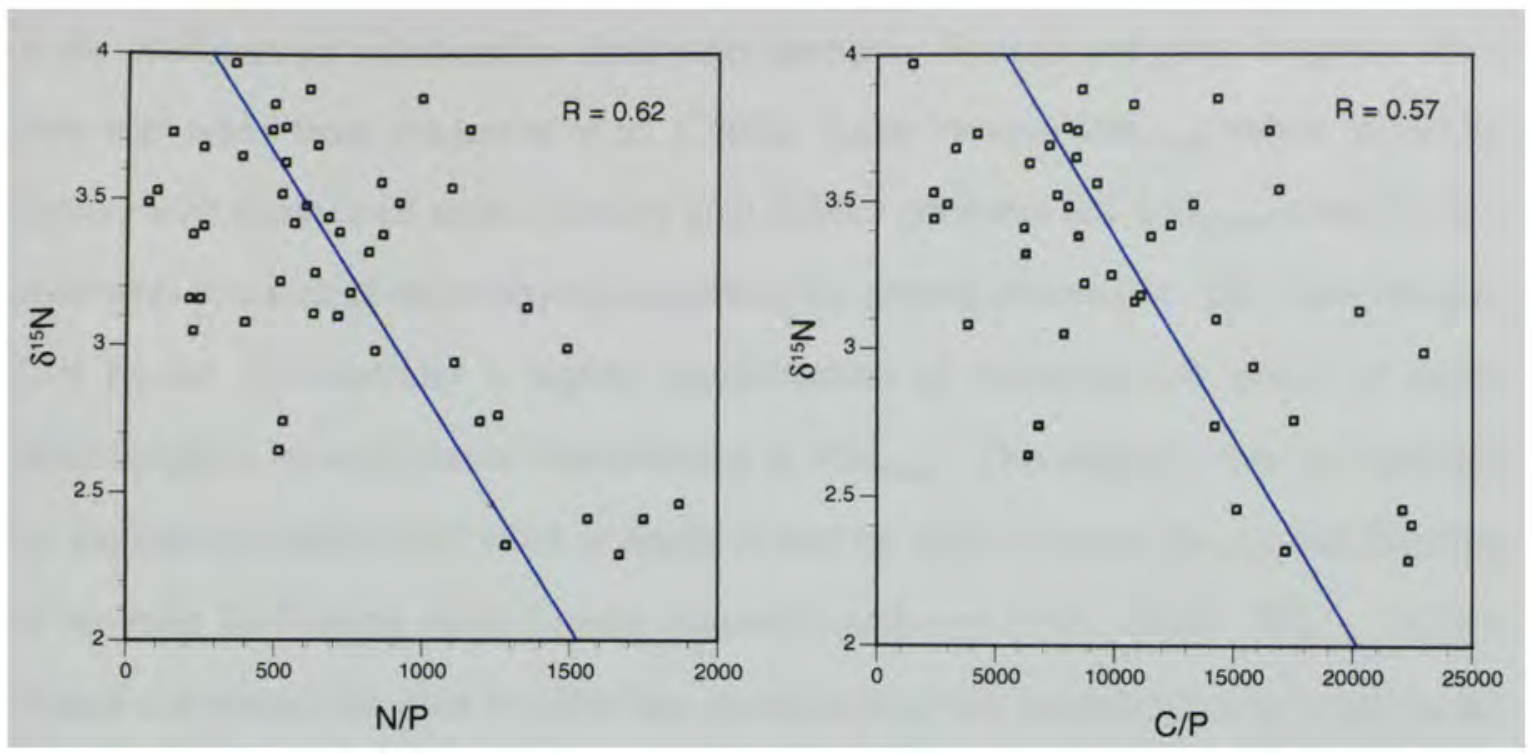

FIGURE $25 \mathrm{~N} / \mathrm{P}$ and $\mathrm{C} / \mathrm{P}$ ratios plotted vs. $\delta^{13} \mathrm{C}$ and $\delta^{15} \mathrm{~N}$. Low P-values, as indicated by high N/P and $\mathrm{C} / \mathrm{P}$ values, show most depleted $\delta^{15} \mathrm{~N}$. Data suggests $\mathrm{P}$ controls production and subsequent isotope ratios within Lake Monroe sediment. High $\delta^{15} \mathrm{~N}$ corresponds with low N/P and C/P (high $\mathrm{P}$ concentration).

loading suggests that there is a relationship between a lake's trophic state and the nutrients entering the lake, and that this relationship can be quantified (Cole et al., 2002).

A study of five shallow, eutrophic lakes (including Lake Jesup, immediately south of Lake Monroe, see Fig.2) by Kenney et al. (2002) demonstrates that following P loading in the late $19^{\text {th }}$ and early $20^{\text {th }}$ centuries, the studied lakes produced organic sediments with an increasing contribution from phytoplankton. The authors suggest, using their $\mathrm{P}$ data and $\mathrm{C} / \mathrm{N}$ ratios, a gradual or transitional period between macrophyte and phytoplankton dominated states. The Lake Monroe phosphorus record matches well with the $\mathrm{C} / \mathrm{N}$ record. Lower values of $\mathrm{P}$ indicate macrophyte dominance, which is observed in the record as high $\mathrm{C} / \mathrm{N}$ values. This relationship is illustrated particularly well at depth.

Submersed macrophyte dominance may also be inferred from concentrations of sponge biogenic silica ( $\mathrm{BSi}_{\text {sponge }}$ ) (Kenney et al., 2002), as submersed aquatic vegetation 
is the predominant substrate for freshwater sponges. Sponge and plant biogenic silica data was taken from Anderson et al. (2005). Lake Monroe $\mathrm{BSi}_{\text {sponge }}$ values generally decline with depth in all cores. Kenney et al. (2002) attributes low $\mathrm{BSi}_{\text {sponge }}$ values in lake sediments to a lack of macrophytes supporting the growth of sponges. The Lake Monroe $\mathrm{C} / \mathrm{N}$ record demonstrates a higher concentration of cellulose-rich plants at depth (macrophytes) yet a decreased concentration of $\mathrm{BSi}_{\text {sponge. }}$. This anomaly may be explained by increased dissolution of silica at depth caused by either frequent drying and flooding or scouring by flowing water (stream channel) (Anderson et al., 2005). $\mathrm{BSi}_{\text {sponge }}$ values should not always be used to infer the presence of either macrophytes or algae in the sediment record as the Lake Monroe data has indicated additional explanations. 


\section{CONCLUSION}

Geochemical and radiometric analyses performed on Lake Monroe sediments record the changes in the source of primary production as brought about by land use changes and nutrient loading within the MSJRB. Increased concentrations of phosphorus throughout the $20^{\text {th }}$ Century drove higher rates of primary productivity, and in turn accounted for increased sediment and $\mathrm{C}$ and $\mathrm{N}$ accumulation. These trends are seen in other waters in Florida, both within and outside of the MSJRB, and infer anthropogenic forcing as the primary cause for change. $\mathrm{C} / \mathrm{N}$ ratios reflect increasing contributions of algae to the sediment, synonymous with an increasing trophic gradient, algal primary production, and a sedimentological shift from ancient peat to modern gyttja and floc.

Perhaps the most convincing of the applied geochemical indicators in this study, in the case of the Lake Monroe sediment record, may be the stable isotope data. When considering the stable isotopic record within the context of trophic state change, the observed relative isotopic enrichment up core is a classic example of decreased isotopic discrimination as a direct result of increased primary production. This trend may be correlated to supply of phosphorus to the Lake Monroe basin, which greatly increased post-1920. It is important to note that both $\delta^{13} \mathrm{C}$ and $\delta^{15} \mathrm{~N}$ values become more depleted in the most recent sediments ( $10 \mathrm{yrs})$, possibly indicating a period of decreased production and increased isotopic discrimination associated with a decrease in the delivery of nutrients to the St. Johns River both upstream as well as in the basin of influence.

The sediments recovered from Lake Monroe all hold paleoecololgical significance, yet the uppermost fluid-mud or floc layer may be the most important of all sediments. Not only is floc the sediment indicative of the current biological and sedimentological regime at Lake Monroe, but its presence may hold a greater control 
over the future state of the lake. A classic example of a eutrophic lake resisting efforts to reverse its trophic state may be found at Lake Apopka. Lake Apopka located in central Florida, underwent a well documented shift from a clear macrophyte dominated lake, to a turbid algal lake in the year 1947 (Bachmann et al., 1999). Recently, numerous measures undertaken to remediate water quality within the lake have not produced the desired results. It has been documented (Bachmann, 2000; Bachmann, 2001; Bachmann, 1999) that the presence of a flocculent layer is preventing the expected and desired shift to a clear macrophyte dominated lake, as the continual re-suspension of this layer by wind and waves has contributed to the persistent state. Not only does this fluid mud layer, which covers $90 \%$ of the lakebed to an average depth of $45 \mathrm{~cm}$, release nutrients into the water column, but it also prevents the rooting of submerged macrophytes (Bachmann et al., 2001).

A similar flocculent layer was recovered at Lake Monroe (Anderson et al., 2003). Although the floc layer at Lake Monroe is not as thick as that at Lake Apopka, its presence still suggests suspension of underlying consolidated sediments and nutrient release to the water column. This floc layer needs to be monitored, as its growth will likely be directly related to continued eutrophication.

An improved age model would constrain and possibly identify the actual timing of eutrophication within Lake Monroe. It is easy to look at the sediment record and attribute the onset of eutrophication to land development throughout the $20^{\text {th }}$ century, but that may not have been the case. Storm and wind events, common to the state of Florida, very likely could have forever changed Lake Monroe at a time much later than initial occupation and land use change. The dating of recent sediments at Lake Monroe was hindered by the lack of total ${ }^{210} \mathrm{~Pb}$ activity in the cores, a phenomenon observed in other Florida lakes (Brenner et al., 2001) and likely due to the outflow of fine-grained ${ }^{210} \mathrm{~Pb}$ bearing sediments, 
Radiocarbon dating of older sediments is also of interest for future paleolimnological studies in this area. Though there is no immediate connection in the geochemical record between the older basal sediments and recent eutrophication, additional radiocarbon dates could contribute critical information to the geological history of the St. Johns River valley and the state of Florida.

This study concentrated on the contributing factors within the Lake Monroe subbasin. It is recognized and addressed that changes throughout the Upper St. Johns River basin (USJRB) south of Lake Monroe, could also have an effect on waters downstream. Paleolimnological studies of lakes and other waterbodies in this region were cited when appropriate, but more work within the USJRB and MSJRB could further highlight the changes occurring within Lake Monroe.

A number of factors can influence the sedimentary geochemical record of OM, so it is imperative for a multi-proxy study to have good agreement between all indicators before any conclusions or projections of trophic state change can be theorized. The Lake Monroe data shows general stratigraphic agreement between chemical parameters (TOC, TIC, TN, TP, C/N $, \delta^{13} \mathrm{C}, \delta^{15} \mathrm{~N}$ ), biogenic silica, diatoms (Anderson et al., 2005), and trophic change, indicating increased primary production due to nutrient $(\mathrm{P})$ loading causing an increased and persistent eutrophic state.

Other indicators of trophic state change beyond those applied throughout this study must also be considered. The isotope and nutrient records can not stand alone, and important indicators such as biomarkers (Filley et al., 2001) and water column $\mathrm{Chl} a(\mathrm{Gu}$ et al., 1996) should be considered in every study to further investigate source and productivity changes. Although this study did not address those indicators, the results presented here have provided an important paleolimnological record to the state of Florida. 


\section{REFERENCES}

Ali, A., Reddy, K.R., and DeBusk, W.F., 1988, Seasonal changes in sediment and water chemistry of a subtropical shallow eutrophic lake: Hydrobiologia, v. 159, p. 159167.

Alvisi, F., and Frignani, M., 1996, ${ }^{210} \mathrm{~Pb}$-derived sediment accumulation rates for the central Adriatic Sea and crater lakes Albano and Nemi (central Italy): Memorie dell'Instituto Italiano di Idrobiologia, v. 55, p. 303-320.

Anderson, W.T., Gaiser, E.E., and Scinto, L.J., 2003, Sediment nutrient characteristics and paleolimnological reconstruction of Lake Monroe, Florida, USA.: Miami, Southeast Environmental Research Center, F.I.U., p. 1-28.

Anderson, W.T., Scinto, L.J., Gaiser, E.E., Carroll, B., Quillen, A., and Haberer, J., 2005, Lake Monroe Sediment Accumulation and Past Water Quality: Miami, Southeast Environmental Research Center, p. 196.

Appleby, P.G., 2001, Basin Analysis, Coring, and Chronological Techniques, in Last, W.M., and Smol, J.P., eds., Tracking Environmental Change Using Lake Sediments, Volume 1: Basin Analysis, Coring, and Chronological Techniques: Dordrecht, Kluwer Academic Publishers, p. 171-203.

Bachmann, R.W., Hoyer, M.V., and Jr., D.E.C., 1999, The restoration of Lake Apopka in relation to alternative stable states: Hydrobiologia, v. 394, p. 219-232.

,- 2000 , Internal heterotrophy following the switch from macrophytes to algae in Lake Apopka, Florida: Hydrobiologia, v. 418, p. 217-227.

-, 2001, Evaluation of recent limnological changes at Lake Apopka: Hydrobiologia, v. 448, p. 19-26.

Barraclough, J.T., 1962, Ground-water resources of Seminole County, Florida: Tallahassee, Florida Geological Survey, p. 91.

Bjorck, S., and Wohlfarth, B., 2001, 14C Chronostratigraphic techniques in paleolimnology, in Last, W.M., and Smol, J.P., eds., Tracking Environmental Change Using Lake Sediments, Volume 1: Basin Analysis, Coring, and Chronological Techniques: Dordrecht, Kluwer Academic Publishers, p. 205-246.

Brenchley, P.J., and Harper, D.A.T., 1998, Paleoecology: Ecosystems, environments and evolution: London, Chapman \& Hall, 402 p. 
Brenner, M., Schelske, C.L., and Keenan, L.W., 2001, Historical rates of sediment and nutrient accumulation in marshes of the Upper St. Johns River Basin, Florida, USA: Journal of Paleolimnology, v. 26, p. 241-257.

Brenner, M., Whitmore, T.J., Curtis, J.H., Hodell, D.A., and Schelske, C.L., 1999a, Stable isotope signatures of sedimented organic matter as indicators of historic lake trophic state: Journal of Paleolimnology, v. 22, p. 205-221.

Brenner, M., Whitmore, T.J., Lasi, M.A., Cable, J.E., and Cable, P.H., 1999b, A multiproxy trophic state reconstruction for shallow Orange Lake, Florida, USA: possible influence of macrophytes on limnetic nutrient concentrations: Journal of Paleolimnology, v. 21, p. 215-233.

Brooks, H.K., 1968, The Plio-Pleistocene of Florida with special reference to the strata outcropping on the Caloosahatchee River., in Perkins, R.D., ed., Late Cenozoic stratigraphy of south Florida: Miami, Miami Geological Society, p. 3-42.

Burgis, M.J., and Morris, P., 1987, The Natural History of Lakes: Cambridge, Cambridge University Press, 218 p.

Cohen, A.S., 2003, Paleolimnology: New York, Oxford University Press, 500 p.

Cole, G.A., 1994, Textbook of Limnology: Prospect Heights, Waveland Press, Inc., 412 p.

Cole, J.J., Carpenter, S.R., Kitchell, J.F., and Pace, M.L., 2002, Pathways of organic carbon utilization in small lakes: Results from a whole-lake $13 \mathrm{C}$ addition and coupled model: Limnology and Oceanography, v. 47, p. 1664-1675.

Colman, S.M., Bradbury, J.P., and Rosenbaum, J.G., 2004, Paleolimnology and paleoclimate studies in Upper Klamath Lake, Oregon: Journal of Paleolimnology, v. 31 , p. $129-138$.

Compton, J.S., 1997, Origin and Paleoceanographic Significance of Florida's Phosphorite Deposits, in Randazzo, A.F., and Jones, D.S., eds., The Geology of Florida: Gainesville, University Press of Florida, p. 195-216.

Davies, T.D., and Cohen, A.D., 1989, Composition and significance of the peat deposits of Florida Bay: Bulletin of Marine Science, v. 44, p. 387-398.

Dodge, R.E., Fairbanks, R.G., Benninger, L.K., and Maurrasse, F., 1983, Pleistocene Sea Levels from Raised Coral Reefs in Haiti: Science, v. 219, p. 1423-1425. 
Eilers, J.M., J.Kann, Cornett, J., Moser, K., and Amand, A.S., 2004, Paleolimnological evidence of change in a shallow, hypereutrophic lake: Upper Klamath Lake, Oregon, USA: Hydrobiologia, v. 520, p. 7-18.

EPA, U.S., 1992, Restoration of Florida's Upper St. Johns River Basin helps heal headwater marshes, Environmental Protection Agency's Office of Wetlands, Oceans, \& Watersheds, p. 1.

Filley, T.R., Freeman, K.H., Bianchi, T.S., Baskaran, M., Colarusso, L.A., and Hatcher, P.G., 2001, An isotopic biogeochemical assessment of shifts in organic matter input to Holocene sediments from Mud Lake, Florida: Organic Geochemistry, v. 32 , p. 1153-1167.

Frouz, J., Lobinske, R., and Ali, A., 2004, Influence of Chironomidae (Diptera) fecal pellet accumulation on lake sediment quality and larval abundance of pestiferous midge Glyptotendipes paripes: Hydrobiologia, v. 518, p. 169-177.

Glew, J.R., Smol, J.P., and Last, W.M., 2001, Sediment core collection and extrusion, in Last, W.M., and Smol, J.P., eds., Tracking Environmental Change Using Lake Sediments, Volume 1: Basin Analysis, Coring, and Chronological Techniques: Dordrecht, Kluwer Academic Publishers, p. 73-105.

Grimm, E.C., George L. Jacobson, J., Watts, W.A., Hansen, B.C.S., and Maasch, K.A., 1993, A 50,000-Year Record of Climate Oscillations from Florida and Its Temporal Correlation with the Heinrich Events: Science, v. 261, p. 198-201.

Gu, B., Schelske, C.L., and Brenner, M., 1996, Relationship between sediment and plankton isotope ratios and primary productivity in Florida lakes: Canadian Journal of Fisheries and Aquatic Sciences, v. 53, p. 875-883.

Hodell, D.A., and Schelske, C.L., 1998, Production, Sedimentation, and Isotopic Composition of Organic Matter in Lake Ontario: Limnology and Oceanography, v. 43 , p. $200-214$.

Hoefs, J., 1997, Stable Isotope Geochemistry: New York, Springer-Verlag.

Ioviono, A.J., and Bradley, W.H., 1969, The role of larval chironomide in the production of lacustrine copropel in Mud Lake, Marion County, Florida: Limnology and Oceanography, v. 14, p. 898-905.

Jennings, E., Mills, P., Jordan, P., Jensen, J.-P., Sondergaard, M., Barr, A., Glasgow, G., and Irvine, K., 2003, Eutrophication from Agricultural Sources: Seasonal Patterns and Effects of Phosphorous: Wexford, Environmental Protection Agency, p. 71. 
Jinglu, W., Gagan, M.K., Xuezhong, J., Weilan, X., and Sumin, W., 2004, Sedimentary geochemical evidence for recent eutrophication of Lake Chenghai, Yunnan, China: Journal of Paleolimnology, v. 32, p. 85-94.

Kaushal, S., and Binford, M.W., 1999, Relationship between C:N ratios of lake sediments, organic matter sources, and historical deforestation in Lake Pleasant, Massachusetts, USA: Journal of Paleolimnology, v. 22, p. 439-442.

Kenney, W.F., Waters, M.N., Schelske, C.L., and Brenner, M., 2002, Sediment records of phosphorous-driven shifts to phytoplankton dominance in shallow Florida lakes: Journal of Paleolimnology, v. 27, p. 367-377.

Lane, E., 1994, Florida's Geological History and Geological Resources, in Lane, E., ed., Volume 35: Tallahassee, Florida Geological Survey.

Last, W.M., and Smol, J.P., 2001, Tracking Environmental Change Using Lake Sediments, Basin Analysis, Coring, and Chronological Techniques, Volume 1: Dordrecht, Kluwer Academic Publishers, p. 548.

Lehmann, M.F., Bernasconi, S.M., and McKenzie, J., 2004, Seasonal variation of the $\delta^{13} \mathrm{C}$ and $\delta^{15} \mathrm{~N}$ or particulate and dissolved carbon and nitrogen in Lake Lugano: Constraints on biogeochemical cycling in a eutrophic lake: Limnology and Oceanography, v. 49, p. 415-429.

McFadden, M.A., Mullins, H.T., Patterson, W.P., and Anderson, W.T., 2004, Paleoproductivity of eastern Lake Ontario over the past 10,000 yr.: Limnology and Oceanography.

McKenzie, J.A., 1985, Carbon isotopes and productivity in the lacustrine and marine environment: In Lakes, p. 99-117.

Meyers, P.A., 1997, Organic geochemical proxies of paleoceanographic, paleolimnologic, and paleoclimatic processes: Organic Geochemistry, v. 27, p. 213-250.

,- 2003 , Applications of organic geochemistry to paleolimnological reconstructions: a summary of examples from the Laurentian Great Lakes: Organic Geochemistry, v. 34, p. 261-289.

Meyers, P.A., and Lallier-Verges, E., 1999, Lacustrine sedimentary organic matter records of Late Quaternary paleoclimates: Journal of Paleolimnology, v. 21, p. 345-372.

Miller, J., 1998, An Environmental History of Northeast Florida: Gainesville, University Press of Florida, $41 \mathrm{p}$. 
Miller, J.A., 1997, Hydrogeology of Florida, in Randazzo, A.F., and Jones, D.S., eds., The Geology of Florida: Tallahassee, University Press of Florida, p. 69-88.

Osmond, J.K., May, J.P., and Tanner, W.F., 1970, Age of the Cape Kennedy Barrier-andLagoon Complex: Journal of Geophysical Research, v. 75, p. 469-479.

Peterson, B.J., and Fry, B., 1987, Stable Isotopes in Ecosystem Studies: Annual Review of Ecology and Systematics, v. 18, p. 293-320.

Phelps, G.G., and German, E.R., 1996, Water Budgets, Water Quality, and Analysis of Nutrient Loading of the Winter Park Chain of Lakes, Central Florida, 1989-1992: Tallahassee, U.S.G.S., p. 96.

Pirkle, W.A., 1971, The offset course of the St. Johns River, Florida: Southeastern Geology, v. 13, p. 39-59.

Randazzo, A.F., 1997, The Sedimentary Platform of Florida: Mesozoic to Cenozoic, in Randazzo, A.F., and Jones, D.S., eds., The Geology of Florida: Gainesville, University Press of Florida, p. 39-56.

Randazzo, A.F., and Jones, D.S., 1997, The Geology of Florida: Gainesville, University Press of Florida, p. 327.

Schelske, C.L., and Hodell, D.A., 1991, Recent changes in productivity and climate of Lake Ontario detected by isotopic analysis of sediments: Limnology and Oceanography, v. 36, p. 961-975.

,- 1995 , Using carbon isotopes of bulk sedimentary organic matter to reconstruct the history of nutrient loading and eutrophication in Lake Erie: Limnology and Oceanography, v. 40(5), p. 918-929.

Schiffer, D.M., 1998, Hydrology of Central Florida Lakes: A Primer, U.S. Geological Survey, p. 45.

Schleser, G.H., 1985, Parameters determining carbon isotope ratios in plants, in Frenzel, B., Stauffer, B., and Weiss, M.M., eds., Problems of Stable Isotopes in Tree-rings, Lake Sediments and Peat-bogs as Climatic Evidence for the Holocene, Volume 15: Stuttgart, Gustav Fischer Verlag, p. 71-96.

Schmidt, W., 1997, Geomorphology and Physiography of Florida, in Randazzo, A.F., and Jones, D.S., eds., The Geology of Florida: Gainesville, University Press of Florida, p. 1-12. 
Scholl, D.W., and Stuiver, M., 1967, Recent Submergence of Southern Florida: A comparison with Adjacent coasts and Other Eustatic Data: Geological Society of America Bulletin, v. 78, p. 437-454.

Scott, T., 1997, Miocene to Holocene History of Florida, in Randazzo, A.F., and Jones, D.S., eds., The Geology of Florida: Tallahassee, University Press of Florida, p. 327.

SJRWMD, 1980, Upper St. Johns River Basin Surface Water Management Plan: Palatka, St. Johns River Water Management District, p. 500.

—, 2002, Middle St. Johns River Basin Surface Water Improvement and Management Plan: Palatka, SJRWMD, p. 92.

Sondergaard, M., Jensen, J.P., and Jeppesen, E., 2001, Retention and Internal Loading of Phosphorous in Shallow, Eutrophic Lakes: The Scientific World, v. 1, p. 427-442.

Sonzogni, W.C., Chapra, S.C., Armstrong, D.E., and Logan, T.J., 1982, Bioavailibility of phosphorous inputs to lakes: Journal of Environmental Quality, v. 11, p. 555-563.

Talbot, M.R., and Laerdal, T., 2000, The Late Pleistocene - Holocene palaeolimnology of Lake Victoria, East Africa, based upon elemental and isotopic analyses of sedimentary organic matter: Journal of Paleolimnology, v. 23, p. 141-164.

Teranes, J.L., McKenzie, J.A., Lotter, A.F., and Sturm, M., 1999, Stable Isotope Response to Lake Eutrophication: Calibration of a High-Resolution Lacustrine Sequence from Baldeggersee, Switzerland: Limnology and Oceanography, v. 44, p. 320-333.

Terranes, J., and Bernasconi, S., 2000, The record of nitrate utilization and productivity limitation provided by $\delta^{15} \mathrm{~N}$ values in lake organic matter - A study of sediment trap and core sediments from Baldeggersee, Switzerland: Limnology and Oceanography, v. 44, p. 801-813.

Watts, W.A., 1975, A late Quaternary record of vegetation from Lake Annie, southcentral Florida: Geology, p. 344-346.

Watts, W.A., and Hansen, B.C.S., 1988, Environments of Florida in the late Wisconsin and Holocene, in Purdy, B.A., ed., Wet Site Archaelogy: Caldwell, The Telford Press, p. 307-323.

White, W.A., 1970, The Geomorphology of the Florida Peninsula: Tallahassee, Bureau of Geology, p. 147. 
Wright, H.E., 1991, Coring Tips: Journal of Paleolimnology, v. 6, p. 37-49.

Wyrick, G.G., 1960, The ground-water resources of Volusia County, Florida, Florida Geological Survey Report of Investigations, p. 65. 


\section{APPENDICES}

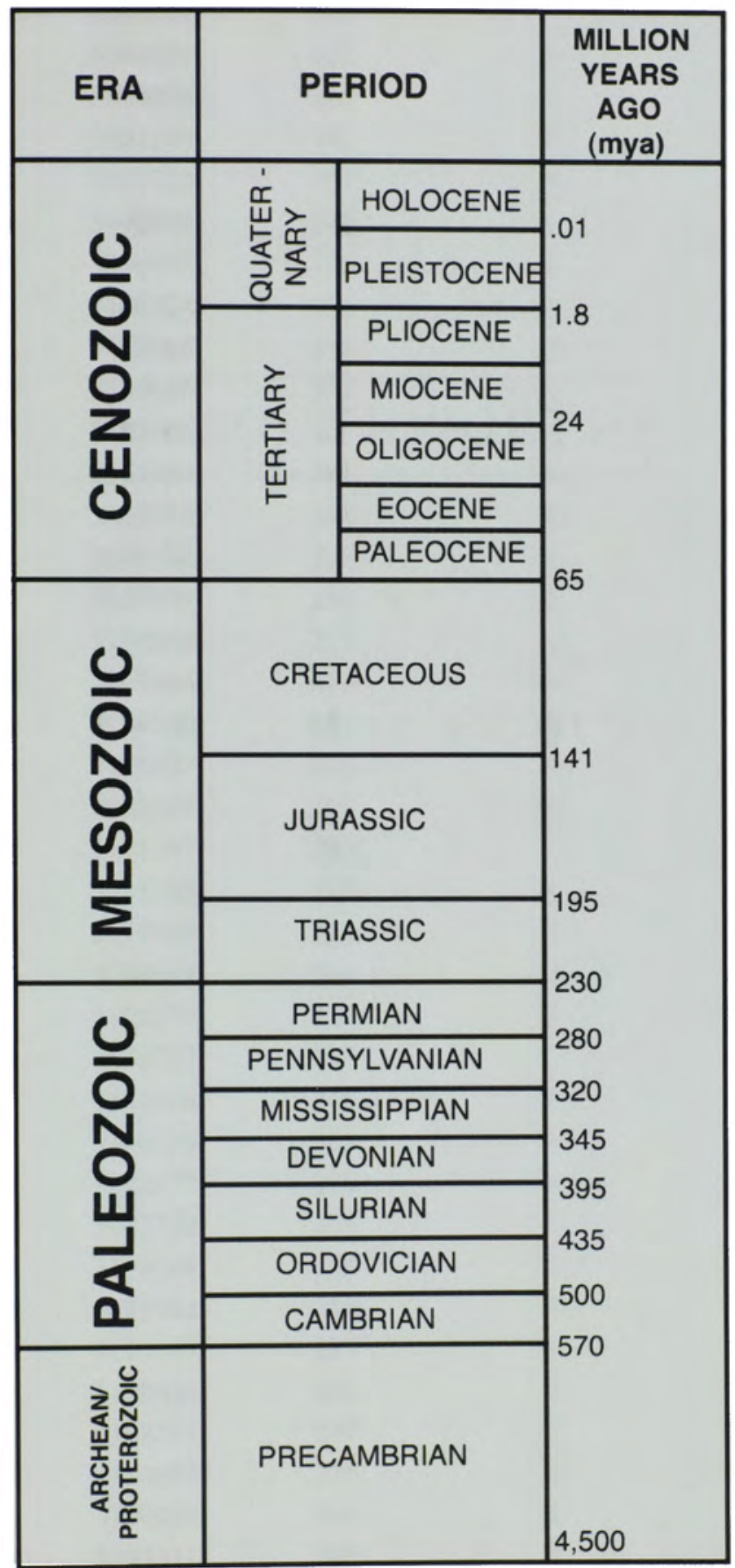

FIGURE A-1 Standard geologic timescale. 
TABLE A-1 Sediment and water survey results from field measurements recorded at Lake Monroe, FL, June 25-27, 2003.

\begin{tabular}{|c|c|c|c|c|c|c|}
\hline Core & $\begin{array}{l}\text { UTM X } \\
\text { coord. }\end{array}$ & $\begin{array}{l}\text { UTM Y } \\
\text { coord. }\end{array}$ & $\begin{array}{c}\text { Water depth } \\
\text { (cm) }\end{array}$ & $\begin{array}{c}\text { Floc thickness } \\
(\mathrm{cm})\end{array}$ & $\begin{array}{c}\text { Sediment depth } \\
\text { (cm) }\end{array}$ & $\begin{array}{c}\text { Sample } \\
\text { date }\end{array}$ \\
\hline LM-01-03 & 469868 & 3189912 & 192 & 3 & 169 & $6 / 26 / 03$ \\
\hline LM-02-03 & 470147 & 3189991 & 117 & 0 & 176 & $6 / 26 / 03$ \\
\hline LM-03-03 & 470623 & 3189038 & 226 & 8 & 59 & $6 / 26 / 03$ \\
\hline LM-04-03 & 470664 & 3191190 & 55 & 6 & 111 & $6 / 27 / 03$ \\
\hline LM-05-03 & 470968 & 3191733 & 75 & 8 & 84 & $6 / 26 / 03$ \\
\hline LM-06-03 & 471038 & 3190070 & 242 & 7 & 153 & $6 / 26 / 03$ \\
\hline LM-07-03 & 471120 & 3190878 & 194 & 0 & 57 & $6 / 26 / 03$ \\
\hline LM-08-03 & 471307 & 3188524 & 116 & 0 & 83 & $6 / 26 / 03$ \\
\hline LM-09-03 & 471425 & 3189985 & 243 & 17 & 190 & $6 / 26 / 03$ \\
\hline LM-10-03 & 471463 & 3189019 & 237 & 7 & 154 & $6 / 26 / 03$ \\
\hline LM-11-03 & 471644 & 3192364 & 84 & 2 & 80 & $6 / 27 / 03$ \\
\hline LM-12-03 & 471618 & 3191567 & 181 & 0 & 39 & $6 / 26 / 03$ \\
\hline LM-13-03 & 471712 & 3189710 & 248 & 8 & 131 & $6 / 26 / 03$ \\
\hline LM-14-03 & 471810 & 3188148 & 227 & 3 & 193 & $6 / 26 / 03$ \\
\hline LM-15-03 & 471863 & 3192098 & 185 & 0 & 63 & $6 / 26 / 03$ \\
\hline LM-16-03 & 472171 & 3190945 & 233 & 10 & 209 & $6 / 26 / 03$ \\
\hline LM-17-03 & 472216 & 3188463 & 235 & 11 & 207 & $6 / 26 / 03$ \\
\hline LM-18-03 & 472656 & 3189350 & 261 & 98 & 90 & $6 / 26 / 03$ \\
\hline LM-19-03 & 472694 & 3192767 & 210 & 0 & 39 & $6 / 26 / 03$ \\
\hline LM-20-03 & 472732 & 3190121 & 255 & 20 & 157 & $6 / 26 / 03$ \\
\hline LM-21-03 & 472753 & 3191257 & 265 & 7 & 163 & $6 / 26 / 03$ \\
\hline LM-22-03 & 472820 & 3191128 & 267 & 5 & 124 & $6 / 26 / 03$ \\
\hline LM-23-03 & 472864 & 3187942 & 224 & 5 & 250 & $6 / 27 / 03$ \\
\hline LM-24-03 & 472906 & 3190044 & 264 & 14 & 176 & $6 / 26 / 03$ \\
\hline LM-25-03 & 472999 & 3193177 & 124 & 0 & 23 & $6 / 26 / 03$ \\
\hline LM-26-03 & 473236 & 3188747 & 257 & 5 & 135 & $6 / 27 / 03$ \\
\hline LM-27-03 & 473427 & 3192010 & 261 & 5 & 163 & $6 / 26 / 03$ \\
\hline LM-28-03 & 473468 & 3190739 & 265 & 4 & 171 & $6 / 26 / 03$ \\
\hline LM-29-03 & 473476 & 3192577 & 248 & 5 & 146 & $6 / 26 / 03$ \\
\hline LM-30-03 & 473486 & 3187779 & 219 & 2 & 100 & $6 / 27 / 03$ \\
\hline LM-31-03 & 473681 & 3189308 & 268 & 5 & 178 & $6 / 27 / 03$ \\
\hline LM-32-03 & 473759 & 3191982 & 258 & 7 & 168 & $6 / 26 / 03$ \\
\hline LM-33-03 & 473770 & 3193147 & 217 & 5 & 179 & $6 / 26 / 03$ \\
\hline LM-34-03 & 473943 & 3188366 & 234 & 6 & 223 & $6 / 27 / 03$ \\
\hline LM-35-03 & 474174 & 3188581 & 257 & 7 & 194 & $6 / 27 / 03$ \\
\hline LM-36-03 & 474204 & 3190857 & 275 & 7 & 118 & $6 / 27 / 03$ \\
\hline LM-37-03 & 474253 & 3190247 & 264 & 5 & 55 & $6 / 27 / 03$ \\
\hline LM-38-03 & 474543 & 3192311 & 249 & 18 & 159 & $6 / 27 / 03$ \\
\hline LM-39-03 & 474556 & 3187505 & 219 & 12 & 122 & $6 / 27 / 03$ \\
\hline LM-40-03 & 474801 & 3189590 & 264 & 5 & 190 & $6 / 27 / 03$ \\
\hline LM-41-03 & 474879 & 3192973 & 79 & 0 & 161 & $6 / 27 / 03$ \\
\hline
\end{tabular}




\begin{tabular}{llllccc}
\hline \multicolumn{1}{l}{ TABLE A-1 (continued) } & \multicolumn{2}{l}{} \\
\hline LM-42-03 & 474950 & 3188535 & 253 & 5 & 207 & $6 / 27 / 03$ \\
LM-43-03 & 475004 & 3191931 & 253 & 8 & 148 & $6 / 27 / 03$ \\
LM-44-03 & 475086 & 3190659 & 265 & 6 & 80 & $6 / 27 / 03$ \\
LM-45-03 & 475114 & 3191129 & 262 & 12 & 132 & $6 / 27 / 03$ \\
LM-46-03 & 475314 & 3192079 & 243 & 9 & 128 & $6 / 27 / 03$ \\
LM-47-03 & 475576 & 3190088 & 252 & 7 & 136 & $6 / 27 / 03$ \\
LM-48-03 & 475618 & 3188819 & 243 & 5 & 136 & $6 / 25 / 03$ \\
LM-49-03 & 475755 & 3187734 & 223 & 9 & 167 & $6 / 25 / 03$ \\
LM-50-03 & 475874 & 3189626 & 253 & 5 & 168 & $6 / 27 / 03$ \\
LM-51-03 & 475878 & 3190732 & 246 & 7 & 51 & $6 / 27 / 03$ \\
LM-52-03 & 475881 & 3191918 & 142 & 1 & 243 & $6 / 27 / 03$ \\
LM-53-03 & 476106 & 3187281 & 179 & 3 & 200 & $6 / 25 / 03$ \\
LM-54-03 & 476255 & 3187952 & 158 & 4 & 26 & $6 / 25 / 03$ \\
LM-55-03 & 476268 & 3189952 & 238 & 9 & 143 & $6 / 27 / 03$ \\
LM-56-03 & 476767 & 3188005 & 100 & 0 & 29 & $6 / 25 / 03$ \\
LM-57-03 & 476911 & 3189138 & 219 & 5 & 60 & $6 / 27 / 03$ \\
LM-58-03 & 476967 & 3190580 & 181 & 12 & 29 & $6 / 27 / 03$ \\
LM-59-03 & 477122 & 3189854 & 186 & 7 & 175 & $6 / 27 / 03$ \\
LM-60-03 & 477649 & 3188590 & 183 & 5 & 142 & $6 / 27 / 03$ \\
\hline
\end{tabular}


TABLE A-2 Lake Monroe sediment nutrient characteristics. N.D. indicates missing data.

\begin{tabular}{|c|c|c|c|c|c|c|c|}
\hline Core & $\begin{array}{c}\text { Top of } \\
\text { Interval } \\
(\mathbf{c m}) \\
\end{array}$ & $\begin{array}{c}\text { Base of } \\
\text { Interval } \\
(\mathbf{c m}) \\
\end{array}$ & $\begin{array}{r}\text { TC } \\
(\%) \\
\end{array}$ & $\begin{array}{l}\text { TN } \\
(\%) \\
\end{array}$ & $\begin{array}{l}\text { TIC } \\
(\%) \\
\end{array}$ & $\begin{array}{c}\text { TOC } \\
(\%) \\
\end{array}$ & $\begin{array}{c}\mathrm{C}_{\text {org }}: \mathrm{N}_{\text {bulk }} \\
(\mathrm{mol})\end{array}$ \\
\hline LM-03 & 0 & 3 & 4.46 & 0.34 & 2.71 & 1.75 & 6.01 \\
\hline LM-03 & 3 & 6 & 10.2 & 0.88 & 1.28 & 8.92 & 11.83 \\
\hline LM-03 & 6 & 9 & 16.82 & 1.55 & 1.16 & 15.66 & 11.79 \\
\hline LM-03 & 9 & 12 & 14.89 & 1.42 & 0.62 & 14.27 & 11.73 \\
\hline LM-03 & 12 & 15 & 5.16 & 0.56 & 0.67 & 4.49 & 9.36 \\
\hline LM-03 & 15 & 18 & 0.69 & 0.05 & 0.04 & 0.65 & 15.21 \\
\hline LM-03 & 18 & 21 & 1.7 & 0.32 & 0.16 & 1.54 & 5.61 \\
\hline LM-03 & 21 & 24 & 9.35 & 1.36 & 0.82 & 8.53 & 7.32 \\
\hline LM-03 & 24 & 27 & 19.68 & 1.85 & 0.35 & 19.33 & 12.19 \\
\hline LM-03 & 27 & 30 & 23.87 & 2.01 & 0.22 & 23.65 & 13.73 \\
\hline LM-03 & 30 & 33 & 30.53 & 2.55 & 0.27 & 30.26 & 13.84 \\
\hline LM-03 & 33 & 36 & 32.26 & 2.64 & 0.00 & 32.26 & 14.26 \\
\hline LM-03 & 36 & 39 & 30.43 & 2.58 & 0.36 & 30.07 & 13.60 \\
\hline LM-06 & 0 & 3 & 16.12 & 1.59 & N.D. & N.D. & N.D. \\
\hline LM-06 & 3 & 6 & 7.05 & 0.78 & N.D. & N.D. & N.D. \\
\hline LM-06 & 6 & 9 & 6.32 & 0.57 & N.D. & N.D. & N.D. \\
\hline LM-06 & 9 & 12 & 31.46 & 2.61 & 1.33 & 30.13 & 13.47 \\
\hline LM-06 & 12 & 15 & 35.32 & 2.9 & 0.81 & 34.51 & 13.88 \\
\hline LM-06 & 15 & 18 & 38 & 3.2 & N.D. & N.D. & N.D. \\
\hline LM-06 & 18 & 21 & 40.06 & 3.44 & 0.59 & 39.47 & 13.39 \\
\hline LM-06 & 21 & 24 & 40.78 & 3.66 & 0.56 & 40.22 & 12.82 \\
\hline LM-06 & 24 & 27 & 39.13 & 3.52 & 0.78 & 38.35 & 12.71 \\
\hline LM-06 & 27 & 30 & 33.64 & 3.11 & 1.07 & 32.57 & 12.22 \\
\hline LM-06 & 30 & 33 & 36.75 & 3.36 & 0.76 & 35.99 & 12.50 \\
\hline LM-06 & 33 & 36 & 38.68 & 3.44 & 0.73 & 37.95 & 12.87 \\
\hline LM-06 & 36 & 39 & 40.24 & 3.74 & 0.71 & 39.53 & 12.33 \\
\hline LM-06 & 39 & 42 & 42.45 & 3.98 & 0.66 & 41.79 & 12.25 \\
\hline LM-06 & 42 & 45 & 44.51 & 3.84 & 0.54 & 43.97 & 13.36 \\
\hline LM-06 & 45 & 48 & 38.58 & 3.32 & 0.49 & 38.09 & 13.39 \\
\hline LM-06 & 48 & 51 & 41.5 & 3.73 & 0.50 & 41.00 & 12.82 \\
\hline LM-06 & 51 & 54 & 44.96 & 4.4 & 0.46 & 44.50 & 11.80 \\
\hline LM-06 & 54 & 57 & 45.3 & 3.97 & N.D. & N.D. & N.D. \\
\hline LM-06 & 57 & 60 & 40.41 & 3.92 & 0.48 & 39.93 & 11.88 \\
\hline LM-07 & 0 & 3 & 0.39 & 0.1 & 0.02 & 0.37 & 4.32 \\
\hline LM-07 & 3 & 6 & 0.28 & 0.01 & 0.06 & 0.22 & 25.71 \\
\hline LM-07 & 6 & 9 & 0.31 & 0 & 0.08 & 0.23 & N.D. \\
\hline LM-07 & 9 & 12 & 0.3 & 0 & 0.22 & 0.08 & N.D. \\
\hline LM-07 & 12 & 15 & 0.67 & 0.01 & 0.21 & 0.46 & 53.89 \\
\hline LM-07 & 15 & 18 & 0.85 & 0.07 & 0.16 & 0.69 & 11.54 \\
\hline LM-07 & 18 & 21 & 1.31 & 0.15 & 0.13 & 1.18 & 9.21 \\
\hline LM-07 & 21 & 24 & 2.32 & 0.23 & 0.00 & 2.32 & 11.77 \\
\hline LM-07 & 24 & 27 & 1.32 & 0.15 & 0.12 & 1.20 & 9.36 \\
\hline LM-07 & 27 & 30 & 0.79 & 0.09 & 0.05 & 0.74 & 9.61 \\
\hline LM-07 & 30 & 33 & 0.4 & 0.06 & 0.05 & 0.35 & 6.82 \\
\hline LM-07 & 33 & 36 & 0.29 & 0.05 & 0.07 & 0.22 & 5.16 \\
\hline
\end{tabular}




\begin{tabular}{|c|c|c|c|c|c|c|c|}
\hline \multicolumn{8}{|c|}{ TABLE A-2 (continued) } \\
\hline LM-07 & 36 & 39 & 0.19 & 0.02 & 0.03 & 0.16 & 9.36 \\
\hline LM-07 & 39 & 40 & 0.24 & 0 & 0.04 & 0.20 & N.D. \\
\hline LM-13 & 0 & 3 & 9.57 & 0.87 & 4.51 & 5.06 & 6.78 \\
\hline LM-13 & 3 & 6 & 13.65 & 1.08 & 2.18 & 11.47 & 12.39 \\
\hline LM-13 & 6 & 9 & 30.94 & 2.34 & 1.24 & 29.70 & 14.81 \\
\hline LM-13 & 9 & 12 & 36.26 & 2.84 & 1.13 & 35.13 & 14.43 \\
\hline LM-13 & 12 & 15 & 36.52 & 2.95 & 0.94 & 35.58 & 14.07 \\
\hline LM-13 & 15 & 18 & 38.57 & 3.18 & 0.22 & 38.35 & 14.07 \\
\hline LM-13 & 18 & 21 & 39.47 & 3.12 & 0.27 & 39.20 & 14.66 \\
\hline LM-13 & 21 & 24 & 38.27 & 2.81 & 0.08 & 38.19 & 15.86 \\
\hline LM-13 & 24 & 27 & 37.81 & 3.11 & 0.32 & 37.49 & 14.06 \\
\hline LM-13 & 27 & 30 & 28.31 & 2.29 & 4.41 & 23.90 & 12.18 \\
\hline LM-13 & 30 & 33 & 35.58 & 3.14 & 0.83 & 34.75 & 12.91 \\
\hline LM-13 & 33 & 36 & 41.45 & 3.34 & 0.17 & 41.28 & 14.42 \\
\hline LM-13 & 36 & 39 & 36.25 & 2.88 & 0.23 & 36.02 & 14.59 \\
\hline LM-13 & 39 & 42 & 28.5 & 2.51 & 0.17 & 28.33 & 13.17 \\
\hline LM-13 & 42 & 45 & 26.62 & 2.39 & 0.94 & 25.68 & 12.53 \\
\hline LM-13 & 45 & 48 & 23.19 & 1.72 & 1.40 & 21.79 & 14.78 \\
\hline LM-13 & 48 & 51 & & N.D. & N.D. & N.D. & N.D. \\
\hline LM-15 & 0 & 3 & 1.58 & 0.21 & 0.61 & 0.97 & 5.41 \\
\hline LM-15 & 3 & 6 & 2.52 & 0.21 & 0.12 & 2.40 & 13.33 \\
\hline LM-15 & 6 & 9 & 2.03 & 0.18 & 0.14 & 1.89 & 12.25 \\
\hline LM-15 & 9 & 12 & 1.51 & 0.16 & 0.14 & 1.37 & 9.98 \\
\hline LM-15 & 12 & 15 & 1.46 & 0.17 & 0.09 & 1.37 & 9.37 \\
\hline LM-16 & 0 & 3 & 8.16 & 0.98 & 0.13 & 8.03 & 9.56 \\
\hline LM-16 & 3 & 6 & 14.53 & 1.29 & 0.20 & 14.33 & 12.96 \\
\hline LM-16 & 6 & 9 & 30.76 & 2.49 & 0.20 & 30.56 & 14.32 \\
\hline LM-16 & 9 & 12 & 37.18 & 3.06 & 0.40 & 36.78 & 14.02 \\
\hline LM-16 & 12 & 15 & 40.29 & 3.3 & 0.17 & 40.12 & 14.19 \\
\hline LM-16 & 15 & 18 & 38.29 & 3.11 & 0.29 & 38.00 & 14.25 \\
\hline LM-16 & 18 & 21 & 41.42 & 3.5 & 0.49 & 40.93 & 13.64 \\
\hline LM-16 & 21 & 24 & 41.2 & 3.4 & 0.66 & 40.54 & 13.91 \\
\hline LM-16 & 24 & 27 & 34.63 & 2.79 & 0.48 & 34.15 & 14.28 \\
\hline LM-16 & 27 & 30 & 35.75 & 2.75 & 0.33 & 35.42 & 15.03 \\
\hline LM-16 & 30 & 33 & 34.85 & 2.81 & 0.94 & 33.91 & 14.08 \\
\hline LM-16 & 33 & 36 & 37.4 & 3.06 & 0.92 & 36.48 & 13.91 \\
\hline LM-16 & 36 & 39 & 36.22 & 2.88 & 3.59 & 32.63 & 13.22 \\
\hline LM-16 & 39 & 42 & 38.74 & 3.18 & 3.35 & 35.39 & 12.98 \\
\hline LM-16 & 42 & 45 & 36.57 & 3.11 & 1.54 & 35.03 & 13.14 \\
\hline LM-16 & 45 & 48 & 33.99 & 2.69 & 1.42 & 32.57 & 14.13 \\
\hline LM-16 & 48 & 51 & 36.79 & 3.04 & 1.92 & 34.87 & 13.38 \\
\hline LM-22 & 0 & 3 & 24.33 & 2.24 & 7.23 & 17.10 & 8.91 \\
\hline LM-22 & 3 & 6 & 18.96 & 1.42 & 3.16 & 15.80 & 12.98 \\
\hline LM-22 & 6 & 9 & 23.98 & 1.95 & 3.91 & 20.07 & 12.01 \\
\hline LM-22 & 9 & 12 & 34.85 & 2.83 & 1.83 & 33.02 & 13.61 \\
\hline LM-22 & 12 & 15 & 31.58 & 2.4 & 0.58 & 31.00 & 15.07 \\
\hline LM-22 & 15 & 18 & 35.79 & 2.74 & 1.49 & 34.30 & 14.61 \\
\hline LM-22 & 18 & 21 & 39.46 & 3.06 & 2.11 & 37.35 & 14.24 \\
\hline
\end{tabular}




\begin{tabular}{|c|c|c|c|c|c|c|c|}
\hline \\
\hline \multicolumn{8}{|c|}{$\frac{\text { IABLE A-2 (continued) }}{21}$} \\
\hline LM-22 & 24 & 27 & 37.51 & 3.01 & 0.26 & 37.25 & 14.44 \\
\hline LM-22 & 27 & 30 & 30.57 & 2.7 & 0.30 & 30.27 & 13.08 \\
\hline LM-22 & 30 & 33 & 31.39 & 2.56 & 0.41 & 30.98 & 14.12 \\
\hline LM-22 & 33 & 36 & 37.21 & 3.04 & 0.26 & 36.95 & 14.18 \\
\hline LM-22 & 36 & 39 & 42.27 & 3.49 & 0.33 & 41.94 & 14.02 \\
\hline LM-22 & 39 & 42 & 38.94 & 3.26 & 0.68 & 38.26 & 13.69 \\
\hline LM-22 & 42 & 45 & 35.56 & 2.98 & 1.33 & 34.23 & 13.40 \\
\hline LM-22 & 45 & 48 & 29.97 & 2.69 & 0.99 & 28.98 & 12.57 \\
\hline LM-22 & 48 & 51 & 26.1 & 2.37 & 0.98 & 25.12 & 12.37 \\
\hline LM-22 & 51 & 54 & 23.35 & 2.16 & 1.41 & 21.94 & 11.85 \\
\hline LM-26 & 0 & 3 & 9.62 & 1.25 & 0.83 & 8.79 & 8.21 \\
\hline LM-26 & 3 & 6 & 5.53 & 0.65 & 0.20 & 5.33 & 9.56 \\
\hline LM-26 & 6 & 9 & 7.31 & 0.6 & 0.59 & 6.72 & 13.06 \\
\hline LM-26 & 9 & 12 & 21.39 & 1.76 & 1.57 & 19.82 & 13.14 \\
\hline LM-26 & 12 & 15 & 38.61 & 3.33 & 0.96 & 37.65 & 13.19 \\
\hline LM-26 & 15 & 18 & 43.96 & 3.43 & 0.66 & 43.30 & 14.73 \\
\hline LM-26 & 18 & 21 & 43.56 & 3.36 & 1.01 & 42.55 & 14.77 \\
\hline LM-26 & 21 & 24 & 44.31 & 3.38 & 0.49 & 43.82 & 15.13 \\
\hline LM-26 & 24 & 27 & 37.21 & 2.9 & 3.72 & 33.49 & 13.47 \\
\hline LM-26 & 27 & 30 & 32.41 & 2.45 & 2.81 & 29.60 & 14.10 \\
\hline LM-26 & 30 & 33 & 30.81 & 2.3 & 1.67 & 29.14 & 14.78 \\
\hline LM-26 & 33 & 36 & 34.6 & 2.6 & 0.88 & 33.72 & 15.13 \\
\hline LM-26 & 36 & 39 & 35.83 & 2.82 & 1.35 & 34.48 & 14.26 \\
\hline LM-26 & 39 & 42 & 34.1 & 2.7 & 0.38 & 33.72 & 14.57 \\
\hline LM-26 & 42 & 45 & 34.03 & 2.66 & 1.04 & 32.99 & 14.47 \\
\hline LM-26 & 45 & 48 & 29.59 & 2.35 & 1.15 & 28.44 & 14.12 \\
\hline LM-26 & 48 & 51 & 32.48 & 2.49 & 0.46 & 32.02 & 15.00 \\
\hline LM-26 & 51 & 54 & 33.89 & 2.71 & 0.68 & 33.21 & 14.30 \\
\hline LM-28 & 0 & 3 & 11.62 & 1.4 & 2.03 & 9.59 & 7.99 \\
\hline LM-28 & 3 & 6 & 7.95 & 0.89 & 0.68 & 7.27 & 9.53 \\
\hline LM-28 & 6 & 9 & 6.89 & 0.83 & 1.02 & 5.87 & 8.25 \\
\hline LM-28 & 9 & 12 & 8.18 & 1.02 & 0.51 & 7.67 & 8.78 \\
\hline LM-28 & 12 & 15 & 3.67 & 0.43 & 0.57 & 3.10 & 8.40 \\
\hline LM-28 & 15 & 18 & 1.3 & 0.19 & 0.60 & 0.70 & 4.30 \\
\hline LM-28 & 18 & 21 & 0.81 & 0.22 & 0.18 & 0.63 & 3.36 \\
\hline LM-28 & 21 & 24 & 0.79 & 0.21 & 0.07 & 0.72 & 4.02 \\
\hline LM-28 & 24 & 27 & 1.05 & 0.23 & 0.12 & 0.93 & 4.70 \\
\hline LM-28 & 27 & 30 & 1.11 & 0.25 & 0.09 & 1.02 & 4.75 \\
\hline LM-28 & 30 & 33 & 0.92 & 0.23 & 0.07 & 0.85 & 4.33 \\
\hline LM-28 & 33 & 36 & 1.37 & 0.27 & 0.07 & 1.30 & 5.64 \\
\hline LM-28 & 36 & 39 & 1.24 & 0.25 & 0.05 & 1.19 & 5.56 \\
\hline LM-28 & 39 & 42 & 1.25 & 0.19 & 0.15 & 1.10 & 6.76 \\
\hline LM-28 & 42 & 45 & 1.06 & 0.24 & 0.78 & 0.28 & 1.36 \\
\hline LM-3 I & 0 & 3 & 12.73 & 1.66 & 0.00 & 0.00 & \\
\hline LM-31 & 3 & 6 & 10.35 & 1.1 & 0.47 & 9.88 & 10.48 \\
\hline LM-31 & 6 & 9 & 17.86 & 1.42 & 2.40 & 15.46 & 12.70 \\
\hline LM-31 & 9 & 12 & 32.51 & 2.49 & 1.06 & 31.45 & 14.74 \\
\hline
\end{tabular}




\begin{tabular}{|c|c|c|c|c|c|c|c|}
\hline \\
\hline \multicolumn{7}{|c|}{$\frac{\text { TABLE A-2 (continued) }}{12}$} & \\
\hline LM-31 & 15 & 18 & 42.66 & 3.35 & 0.43 & 42.23 & 14.71 \\
\hline LM-31 & 18 & 21 & 42.16 & 3.28 & 0.26 & 41.90 & 14.90 \\
\hline LM-31 & 21 & 24 & 37.69 & 2.92 & 0.23 & 37.46 & 14.97 \\
\hline LM-31 & 24 & 27 & 39.84 & 3.22 & 0.37 & 39.47 & 14.30 \\
\hline LM-31 & 27 & 30 & 32.6 & 2.6 & 0.43 & 32.17 & 14.44 \\
\hline LM-31 & 30 & 33 & 34.96 & 2.63 & 0.18 & 34.78 & 15.43 \\
\hline LM-31 & 33 & 36 & 33.94 & 2.68 & 0.58 & 33.36 & 14.52 \\
\hline LM-31 & 36 & 39 & 36.16 & 2.89 & 0.76 & 35.40 & 14.29 \\
\hline LM-31 & 39 & 42 & 28.61 & 2.39 & 0.09 & 28.52 & 13.92 \\
\hline LM-31 & 42 & 45 & 29.58 & 2.57 & 0.10 & 29.48 & 13.38 \\
\hline LM-31 & 45 & 48 & 29.08 & 2.29 & 0.14 & 28.94 & 14.74 \\
\hline LM-31 & 48 & 51 & 41.34 & 3.12 & 0.11 & 41.23 & 15.42 \\
\hline LM-31 & 51 & 54 & 26.99 & 2.13 & 0.30 & 26.69 & 14.62 \\
\hline LM-31 & 54 & 57 & 18.85 & 1.68 & 0.00 & 0.00 & \\
\hline LM-32 & 0 & 3 & 11.55 & 1.35 & 0.35 & 11.20 & 9.68 \\
\hline LM-32 & 3 & 6 & 10.96 & 1.21 & 0.26 & 10.70 & 10.31 \\
\hline LM-32 & 6 & 9 & 9.82 & 0.99 & 1.44 & 8.38 & 9.87 \\
\hline LM-32 & 9 & 12 & 6.35 & 0.56 & 1.82 & 4.53 & 9.44 \\
\hline LM-32 & 12 & 15 & 3.8 & 0.31 & 0.50 & 3.30 & 12.42 \\
\hline LM-32 & 15 & 18 & 9.42 & 0.67 & 2.29 & 7.13 & 12.42 \\
\hline LM-32 & 18 & 21 & 11.19 & 0.78 & 1.48 & 9.71 & 14.52 \\
\hline LM-32 & 21 & 24 & 24.09 & 1.76 & 1.00 & 23.09 & 15.30 \\
\hline LM-32 & 24 & 27 & 24.27 & 1.8 & 1.00 & 23.27 & 15.08 \\
\hline LM-32 & 27 & 30 & 26.54 & 1.92 & 0.90 & 25.64 & 15.58 \\
\hline LM-32 & 30 & 33 & 32.02 & 2.2 & 0.72 & 31.30 & 16.60 \\
\hline LM-32 & 33 & 36 & 30.07 & 2.17 & 0.62 & 29.45 & 15.83 \\
\hline LM-32 & 36 & 39 & 30.05 & 2.24 & 0.00 & 0.00 & \\
\hline LM-32 & 39 & 42 & 28.67 & 2.08 & 0.87 & 27.80 & 15.60 \\
\hline LM-32 & 42 & 45 & 34.22 & 2.52 & 0.58 & 33.64 & 15.57 \\
\hline LM-32 & 45 & 48 & 42.23 & 2.82 & 0.79 & 41.44 & 17.14 \\
\hline LM-32 & 48 & 51 & 41.49 & 2.9 & 0.75 & 40.74 & 16.39 \\
\hline LM-32 & 51 & 54 & 39.22 & 2.88 & 0.56 & 38.66 & 15.66 \\
\hline LM-32 & 54 & 57 & 40.2 & 2.99 & 0.39 & 39.81 & 15.53 \\
\hline LM-32 & 57 & 60 & 47.38 & 3.55 & 1.21 & 46.17 & 15.17 \\
\hline LM-32 & 60 & 63 & 34.08 & 2.4 & 0.47 & 33.61 & 16.34 \\
\hline LM-32 & 63 & 66 & 39.84 & 2.66 & 0.34 & 39.50 & 17.32 \\
\hline LM-32 & 66 & 69 & 32.66 & 2.37 & 0.25 & 32.41 & 15.95 \\
\hline LM-32 & 69 & 70 & 41.96 & 2.93 & N.D. & N.D. & N.D. \\
\hline LM-37 & 0 & 3 & 15.65 & 1.94 & N.D. & N.D. & N.D. \\
\hline LM-37 & 3 & 6 & 15.35 & 1.88 & 0.29 & 15.06 & 9.35 \\
\hline LM-37 & 6 & 9 & 14.79 & 1.82 & 0.59 & 14.20 & 9.10 \\
\hline LM-37 & 9 & 12 & 13.32 & 1.71 & 0.00 & 0.00 & \\
\hline LM-37 & 12 & 15 & 13.27 & 1.55 & 0.47 & 12.80 & 9.63 \\
\hline LM-37 & 15 & 18 & 12.66 & 1.49 & 2.46 & 10.20 & 7.98 \\
\hline LM-37 & 18 & 21 & 5.26 & 0.32 & 2.04 & 3.22 & 11.73 \\
\hline LM-37 & 21 & 24 & 0.76 & 0.06 & 0.18 & 0.58 & 11.35 \\
\hline LM-37 & 24 & 27 & 0.4 & 0.07 & 0.08 & 0.32 & 5.35 \\
\hline
\end{tabular}




\begin{tabular}{|c|c|c|c|c|c|c|c|}
\hline \multicolumn{8}{|c|}{ TABLE A-2 (continued) } \\
\hline LM-37 & 27 & 30 & 0.87 & 0.02 & 0.45 & 0.42 & 24.33 \\
\hline LM-37 & 30 & 33 & 1.65 & 0.13 & 1.18 & 0.47 & 4.17 \\
\hline LM-39 & 0 & 3 & 4.82 & 0.4 & 0.93 & 3.89 & 11.35 \\
\hline LM-39 & 3 & 6 & 3.13 & 0.3 & 0.78 & 2.35 & 9.14 \\
\hline LM-39 & 6 & 9 & 6.53 & 0.41 & 3.31 & 3.22 & 9.17 \\
\hline LM-39 & 9 & 12 & 12.42 & 0.77 & 9.14 & 3.28 & 4.97 \\
\hline LM-39 & 12 & 15 & 14.25 & 0.96 & 9.77 & 4.48 & 5.45 \\
\hline LM-39 & 15 & 18 & 14.37 & 0.87 & 5.16 & 9.21 & 12.35 \\
\hline LM-39 & 18 & 21 & 32.44 & 2.61 & 3.34 & 29.10 & 13.01 \\
\hline LM-39 & 21 & 24 & 40.86 & 3.31 & 9.02 & 31.84 & 11.22 \\
\hline LM-39 & 24 & 27 & 36.98 & 3.02 & 2.66 & 34.32 & 13.26 \\
\hline LM-39 & 27 & 30 & 39.56 & 3.26 & 0.41 & 39.15 & 14.01 \\
\hline LM-39 & 30 & 33 & 42.88 & 3.43 & 0.77 & 42.11 & 14.32 \\
\hline LM-39 & 33 & 36 & 43.77 & 3.74 & 5.78 & 37.99 & 11.85 \\
\hline LM-39 & 36 & 39 & 43.64 & 3.86 & 1.42 & 42.22 & 12.76 \\
\hline LM-39 & 39 & 42 & 42.66 & 3.74 & 4.83 & 37.83 & 11.80 \\
\hline LM-39 & 42 & 45 & 43.32 & 4.03 & 10.17 & 33.15 & 9.60 \\
\hline LM-42 & 0 & 3 & 10.38 & 1.26 & 0.00 & 0.00 & N.D. \\
\hline LM-42 & 3 & 6 & 11.36 & 1.53 & 0.00 & 0.00 & N.D. \\
\hline LM-42 & 6 & 9 & 11.66 & 1.56 & 0.19 & 11.47 & 8.58 \\
\hline LM-42 & 9 & 12 & 8.52 & 1.02 & 0.48 & 8.04 & 9.19 \\
\hline LM-42 & 12 & 15 & 3.46 & 0.38 & 0.64 & 2.82 & 8.66 \\
\hline LM-42 & 15 & 18 & 3.74 & 0.32 & 0.84 & 2.90 & 10.56 \\
\hline LM-42 & 18 & 21 & 6.68 & 0.65 & 0.49 & 6.19 & 11.11 \\
\hline LM-42 & 21 & 24 & 18.91 & 1.89 & 0.50 & 18.41 & 11.36 \\
\hline LM-42 & 24 & 27 & 39.05 & 3.7 & 0.29 & 38.76 & 12.22 \\
\hline LM-42 & 27 & 30 & 43.52 & 4.01 & 4.81 & 38.71 & 11.26 \\
\hline LM-42 & 30 & 33 & 42.77 & 3.9 & 0.00 & 0.00 & N.D. \\
\hline LM-43 & 0 & 3 & 14.59 & 1.96 & 0.31 & 14.28 & 8.50 \\
\hline LM-43 & 3 & 6 & 11.58 & 1.33 & 0.94 & 10.64 & 9.34 \\
\hline LM-43 & 6 & 9 & 6.81 & 0.54 & 2.07 & 4.74 & 10.24 \\
\hline LM-43 & 9 & 12 & 22.17 & 1.77 & 4.57 & 17.60 & 11.60 \\
\hline LM-43 & 12 & 15 & 36.33 & 3.07 & 0.26 & 36.07 & 13.71 \\
\hline LM-43 & 15 & 18 & 31.88 & 2.62 & 2.18 & 29.70 & 13.22 \\
\hline LM-43 & 18 & 21 & 28.62 & 2.24 & 0.55 & 28.07 & 14.62 \\
\hline LM-43 & 21 & 24 & 29.9 & 2.42 & 0.20 & 29.70 & 14.32 \\
\hline LM-43 & 24 & 27 & 25.09 & 1.92 & 0.22 & 24.87 & 15.11 \\
\hline LM-43 & 27 & 30 & 36.47 & 2.75 & 0.53 & 35.94 & 15.25 \\
\hline LM-43 & 30 & 33 & 32.3 & 2.48 & 0.00 & 0.00 & N.D. \\
\hline LM-43 & 33 & 36 & 32.53 & 2.61 & 3.22 & 29.31 & 13.10 \\
\hline LM-43 & 36 & 39 & 38.04 & 2.89 & 2.99 & 35.05 & 14.15 \\
\hline LM-43 & 39 & 42 & 33.96 & 2.61 & 0.26 & 33.70 & 15.07 \\
\hline LM-45 & 0 & 3 & 10.16 & 1.36 & 0.62 & 9.54 & 8.19 \\
\hline LM-45 & 3 & 6 & 3.39 & 0.4 & 1.76 & 1.63 & 4.74 \\
\hline LM-45 & 6 & 9 & 3.32 & 0.32 & 0.43 & 2.89 & 10.54 \\
\hline LM-45 & 9 & 12 & 6.57 & 0.73 & 0.31 & 6.26 & 10.00 \\
\hline LM-45 & 12 & 15 & 19.25 & 1.91 & 0.36 & 18.89 & 11.54 \\
\hline LM-45 & 15 & 18 & 17.08 & 1.63 & 0.31 & 16.77 & 12.00 \\
\hline
\end{tabular}




\begin{tabular}{|c|c|c|c|c|c|c|c|}
\hline \multicolumn{8}{|c|}{ TABLE A-2 (continued) } \\
\hline LM-45 & 18 & 21 & 31.42 & 2.96 & 0.23 & 31.19 & 12.29 \\
\hline LM-45 & 21 & 24 & 24.75 & 2.19 & 0.26 & 24.49 & 13.05 \\
\hline LM-45 & 24 & 27 & 32.76 & 3.03 & 0.30 & 32.46 & 12.50 \\
\hline LM-45 & 27 & 30 & 30.06 & 2.74 & 0.33 & 29.73 & 12.66 \\
\hline LM-45 & 30 & 33 & 32.54 & 3.16 & 0.29 & 32.25 & 11.91 \\
\hline LM-45 & 33 & 36 & 36.17 & 3.23 & 0.34 & 35.83 & 12.94 \\
\hline LM-45 & 36 & 39 & 34.22 & 3.1 & 0.26 & 33.96 & 12.78 \\
\hline LM-45 & 39 & 42 & 34.73 & 3.01 & 0.89 & 33.84 & 13.12 \\
\hline LM-47 & 0 & 3 & 11.11 & 1.28 & 3.58 & 7.53 & 6.86 \\
\hline LM-47 & 3 & 6 & 7.69 & 0.73 & 0.35 & 7.34 & 11.74 \\
\hline LM-47 & 6 & 9 & 20.01 & 2.01 & 0.52 & 19.49 & 11.31 \\
\hline LM-47 & 9 & 12 & 33.89 & 3.29 & 0.37 & 33.52 & 11.89 \\
\hline LM-47 & 12 & 15 & 39.65 & 3.81 & 0.81 & 38.84 & 11.89 \\
\hline LM-47 & 15 & 18 & 44.47 & 4.2 & 1.35 & 43.12 & 11.98 \\
\hline LM-47 & 18 & 21 & 42.38 & 3.56 & 0.35 & 42.03 & 13.77 \\
\hline LM-49 & 0 & 3 & 2.89 & 0.38 & 0.23 & 2.66 & 8.16 \\
\hline LM-49 & 3 & 6 & 2.43 & 0.29 & 0.36 & 2.07 & 8.34 \\
\hline LM-49 & 6 & 9 & 19.85 & 1.97 & 1.15 & 18.70 & 11.07 \\
\hline LM-49 & 9 & 12 & 29.43 & 2.84 & 0.93 & 28.50 & 11.71 \\
\hline LM-49 & 12 & 15 & 40.58 & 3.92 & 1.30 & 39.28 & 11.69 \\
\hline LM-49 & 15 & 18 & 42.12 & 4.2 & 0.24 & 41.88 & 11.63 \\
\hline LM-49 & 18 & 21 & 41.54 & 4.12 & 0.92 & 40.62 & 11.50 \\
\hline LM-49 & 21 & 24 & 43.06 & 4.25 & 0.14 & 42.92 & 11.78 \\
\hline LM-50 & 0 & 3 & 8.92 & 1.27 & 0.26 & 8.66 & 7.96 \\
\hline LM-50 & 3 & 6 & 11.51 & 1.65 & 0.34 & 11.17 & 7.90 \\
\hline LM-50 & 6 & 9 & 12.39 & 1.33 & 0.12 & 12.27 & 10.76 \\
\hline LM-50 & 9 & 12 & 10.57 & 1.5 & 0.31 & 10.26 & 7.98 \\
\hline LM-50 & 12 & 15 & 10.98 & 1.54 & 0.34 & 10.64 & 8.06 \\
\hline LM-50 & 15 & 18 & 8.31 & 1.14 & 0.44 & 7.87 & 8.06 \\
\hline LM-50 & 18 & 21 & 6.04 & 0.75 & 0.85 & 5.19 & 8.07 \\
\hline LM-50 & 21 & 24 & 3.82 & 0.57 & 0.52 & 3.30 & 6.76 \\
\hline LM-50 & 24 & 27 & 4.49 & 0.77 & 1.73 & 2.76 & 4.18 \\
\hline LM-50 & 27 & 30 & 3.96 & 0.47 & 3.20 & 0.76 & 1.88 \\
\hline LM-50 & 30 & 33 & 5 & 0.42 & 5.32 & 0.00 & N.D. \\
\hline LM-50 & 33 & 36 & 9.39 & 0.73 & 7.94 & 1.45 & 2.33 \\
\hline LM-50 & 36 & 39 & 16.81 & 1.35 & 0.00 & 0.00 & N.D. \\
\hline LM-50 & 39 & 42 & 27.59 & 2.48 & 4.89 & 22.70 & 10.68 \\
\hline LM-50 & 42 & 45 & 28.78 & 2.43 & 0.79 & 27.99 & 13.44 \\
\hline LM-50 & 45 & 48 & 41.01 & 3.75 & 0.66 & 40.35 & 12.55 \\
\hline LM-50 & 48 & 51 & 41.67 & 4.01 & 0.64 & 41.03 & 11.94 \\
\hline LM-50 & 51 & 54 & 42.82 & 3.9 & 0.00 & 0.00 & N.D. \\
\hline LM-50 & 54 & 57 & 44.54 & 4.17 & 0.12 & 44.42 & 12.43 \\
\hline LM-57 & 0 & 3 & 1.17 & 0.14 & 0.00 & 1.17 & 9.75 \\
\hline LM-57 & 3 & 6 & 1.2 & 0.15 & 0.73 & 1.00 & 7.81 \\
\hline LM-57 & 6 & 9 & 1.73 & 0 & 6.45 & 2.93 & N.D. \\
\hline LM-57 & 9 & 12 & 9.38 & 0.55 & 8.65 & 3.79 & 8.03 \\
\hline LM-57 & 12 & 15 & 12.44 & 0.78 & 8.55 & 6.18 & 9.25 \\
\hline LM-57 & 15 & 18 & 14.73 & 0.95 & 8.77 & 5.30 & 6.51 \\
\hline
\end{tabular}




\begin{tabular}{lccccccc}
\hline TABLE A-2 (continued) & \multicolumn{1}{l}{ (18 } & 21 & 14.07 & 0.91 & 8.93 & 5.14 & 6.59 \\
\hline LM-57 & 18 & 24 & 12.63 & 0.89 & 8.77 & 3.86 & 5.06 \\
LM-57 & 21 & 27 & 12.95 & 0.87 & 9.40 & 3.55 & 4.77 \\
LM-57 & 24 & 30 & 13.1 & 0.91 & 9.65 & 3.45 & 4.43 \\
LM-57 & 27 & 33 & 13.43 & 0.87 & 10.03 & 3.40 & 4.56 \\
LM-57 & 30 & 36 & 12.82 & 0.8 & 10.64 & 2.18 & 3.18 \\
LM-57 & 33 & 39 & 12.23 & 0.76 & 10.66 & 1.57 & 2.41 \\
LM-57 & 36 & 42 & 10.82 & 0.48 & 8.32 & 2.50 & 6.07 \\
LM-57 & 39 & 45 & 8.51 & 0.46 & 8.32 & 2.50 & 6.33 \\
LM-57 & 42 & & & & & & \\
\hline
\end{tabular}


TABLE A-3 Lake Monroe ${ }^{210} \mathrm{~Pb}$ activity results from selected intervals. Dated cores include LM-06, LM-28, LM-31, LM-32, LM-45, LM-50B. Sediment accumulation rates from this table were used to calculate MAR's.

\begin{tabular}{|c|c|c|c|c|c|c|c|c|}
\hline Core & $\begin{array}{c}\text { Top of } \\
\text { Interval } \\
(\mathrm{cm}) \\
\end{array}$ & $\begin{array}{c}\text { Base of } \\
\text { Interval } \\
(\mathrm{cm}) \\
\end{array}$ & $\begin{array}{c}\text { Cumulative } \\
\text { Dry Mass } \\
\left(\mathrm{g} / \mathrm{cm}^{2}\right) \\
\end{array}$ & $\begin{array}{c}\text { Age: Base } \\
\text { of Int. } \\
\text { (yr) } \\
\end{array}$ & $\begin{array}{c}\text { Error of } \\
\text { Age } \\
( \pm \text { s.d. }) \\
\end{array}$ & $\begin{array}{l}\text { Date } \\
\text { (A.D.) } \\
\end{array}$ & $\begin{array}{c}\text { Sediment } \\
\text { Accum. } \\
\left(\mathrm{g} / \mathrm{cm}^{2} \mathbf{y r}\right) \\
\end{array}$ & $\begin{array}{c}\text { Error of } \\
\text { Sed. Accum. } \\
( \pm \text { s.d. }) \\
\end{array}$ \\
\hline LM-06 & 0 & 3 & 0.1065 & 8.39 & 3.27 & 1995.1 & 0.0127 & 0.00114 \\
\hline LM-06 & 3 & 6 & 0.462 & 69.8 & 12.98 & 1933.7 & 0.0058 & 0.00105 \\
\hline LM-28 & 0 & 3 & 0.1695 & 4.54 & 1.68 & 1998.9 & 0.0373 & 0.00244 \\
\hline LM-28 & 3 & 6 & 0.5481 & 9.87 & 1.76 & 1993.6 & 0.0711 & 0.00709 \\
\hline LM-28 & 6 & 9 & 0.9672 & 18.52 & 1.99 & 1985 & 0.0485 & 0.00368 \\
\hline LM-28 & 9 & 12 & 1.5126 & 43.29 & 3.39 & 1960.2 & 0.022 & 0.00166 \\
\hline LM-28 & 12 & 15 & 2.334 & 81.52 & 6.72 & 1922 & 0.0215 & 0.00295 \\
\hline LM-31 & 0 & 3 & 0.3279 & 10.94 & 3.7 & 1992.5 & 0.03 & 0.00264 \\
\hline LM-31 & 3 & 6 & 0.8283 & 26.01 & 5.14 & 1977.5 & 0.0332 & 0.00411 \\
\hline LM-3I & 6 & 9 & 1.4706 & 39.99 & 7.26 & 1963.5 & 0.0459 & 0.00909 \\
\hline LM-31 & 9 & 12 & 2.6049 & 72.51 & 18.2 & 1931 & 0.0349 & 0.01257 \\
\hline LM-31 & 12 & 15 & 3.0693 & 89.52 & 30.51 & 1914 & 0.0273 & 0.02043 \\
\hline LM-31 & 15 & 18 & 3.6183 & 113.35 & 63.23 & 1890.1 & 0.023 & 0.03225 \\
\hline LM-32 & 0 & 3 & 0.309 & 9.5 & 1.45 & 1994 & 0.0325 & 0.00157 \\
\hline LM-32 & 3 & 6 & 0.6114 & 21.39 & 1.73 & 1982.1 & 0.0254 & 0.00142 \\
\hline LM-32 & 6 & 9 & 1.0938 & 47.36 & 2.77 & 1956.1 & 0.0186 & 0.00122 \\
\hline LM-32 & 9 & 12 & 1.6251 & 81.69 & 6.66 & 1921.8 & 0.0155 & 0.00204 \\
\hline LM-32 & 12 & 15 & 2.1105 & 109.28 & 13.84 & 1894.2 & 0.0176 & 0.00544 \\
\hline LM-45 & 0 & 3 & 0.3033 & 38.76 & 15.08 & 1964.7 & 0.0078 & 0.00206 \\
\hline LM-50B & 0 & 1 & 0.34 & 4.23 & 3.42 & 1999.6 & 0.0804 & 0.00677 \\
\hline LM-50B & 2 & 3 & 1.62 & 11.43 & 2.84 & 1992.4 & 0.2377 & 0.01871 \\
\hline LM-50B & 4 & 5 & 3.04 & 21.72 & 3.03 & 1982.2 & 0.1162 & 0.00813 \\
\hline LM-50B & 6 & 7 & 4.38 & 36.63 & 3.88 & 1967.2 & 0.082 & 0.00769 \\
\hline LM-50B & 8 & 9 & 5.52 & 54.7 & 5.82 & 1949.2 & 0.0574 & 0.00856 \\
\hline LM-50B & 10 & 11 & 6.585 & 73.7 & 8.99 & 1930.2 & 0.0561 & 0.01351 \\
\hline LM-50B & 12 & 13 & 8.305 & 108.88 & 23.23 & 1895 & 0.0457 & 0.02432 \\
\hline
\end{tabular}


TABLE A-4 Lake Monroe sediment ages according to the cf:cs (constant flux: constant sedimentation) model for cores LM-06, LM-31, LM-32, and LM-45.

\begin{tabular}{|c|c|c|c|c|c|c|}
\hline Core & $\begin{array}{c}\text { Top of } \\
\text { Interval } \\
(\mathrm{cm}) \\
\end{array}$ & $\begin{array}{c}\text { Base of } \\
\text { Interval } \\
(\mathbf{c m}) \\
\end{array}$ & $\begin{array}{c}\text { Cumulative } \\
\text { Dry Mass } \\
\left(\mathrm{g} / \mathrm{cm}^{\mathbf{2}}\right) \\
\end{array}$ & $\begin{array}{c}\text { Age: Base } \\
\text { of interval } \\
(\mathbf{y r}) \\
\end{array}$ & 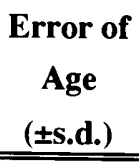 & $\begin{array}{l}\text { Date } \\
\text { (A.D.) } \\
\end{array}$ \\
\hline LM-06 & 0 & 3 & 0.1065 & 9.3 & 4.06 & 1994.1 \\
\hline LM-06 & 3 & 6 & 0.462 & 40.5 & 17.6 & 1962.9 \\
\hline LM-06 & 6 & 9 & 0.8796 & 77.2 & 33.5 & 1926.3 \\
\hline LM-31 & 0 & 3 & 0.3279 & 8.2 & 0.64 & 1995.3 \\
\hline LM-31 & 3 & 6 & 0.8283 & 20.7 & 1.62 & 1982.8 \\
\hline LM-31 & 6 & 9 & 1.4706 & 36.7 & 2.88 & 1966.8 \\
\hline LM-31 & 9 & 12 & 2.6049 & 65 & 5.1 & 1938.5 \\
\hline LM-31 & 12 & 15 & 3.0693 & 76.5 & 6.01 & 1926.9 \\
\hline LM-31 & 15 & 18 & 3.6183 & 90.2 & 7.09 & 1913.2 \\
\hline LM-32 & 0 & 3 & 0.309 & 13.9 & 2.65 & 1989.6 \\
\hline LM-32 & 3 & 6 & 0.6114 & 27.5 & 5.25 & 1976 \\
\hline LM-32 & 6 & 9 & 1.0938 & 49.1 & 9.4 & 1954.3 \\
\hline LM-32 & 9 & 12 & 1.6251 & 73 & 13.96 & 1930.5 \\
\hline LM-32 & 12 & 15 & 2.1105 & 94.8 & 18.13 & 1908.6 \\
\hline LM-45 & 0 & 3 & 0.3033 & 25 & 0 & 1978.5 \\
\hline LM-45 & 3 & 6 & 0.8976 & 73.9 & 0 & 1929.5 \\
\hline
\end{tabular}


TABLE A-5 Lake Monroe sediment age and accumulation rates calculated by c.r.s. (constant rate of supply) model for cores LM-28, LM-31, LM-32, and LM-50B.

\begin{tabular}{ccccccccc}
\hline Core & $\begin{array}{c}\text { Top of } \\
\text { Interval } \\
(\mathbf{c m})\end{array}$ & $\begin{array}{c}\text { Base of } \\
\text { Interval } \\
(\mathbf{c m})\end{array}$ & $\begin{array}{c}\text { Cumulative } \\
\text { Dry Mass } \\
\left(\mathbf{g} / \mathbf{c m}^{2}\right)\end{array}$ & $\begin{array}{c}\text { Age: Base } \\
\text { of Int. } \\
(\mathbf{y r})\end{array}$ & $\begin{array}{c}\text { Error of } \\
\text { Age } \\
(\mathbf{\pm S . d} \text {. })\end{array}$ & $\begin{array}{c}\text { Date } \\
(\mathbf{A . D} .)\end{array}$ & $\begin{array}{c}\text { Sediment } \\
\text { Accum. } \\
\left(\mathbf{g} / \mathbf{c m}^{2} \mathbf{y r}\right)\end{array}$ & $\begin{array}{c}\text { Error of } \\
\text { Sed. Accum. }\end{array}$ \\
\hline \hline LM-28 & 0 & 3 & 0.1695 & 4.54 & 1.68 & 1998.9 & 0.0373 & 0.00244 \\
LM-28 & 3 & 6 & 0.5481 & 9.87 & 1.76 & 1993.6 & 0.0711 & 0.00709 \\
LM-28 & 6 & 9 & 0.9672 & 18.52 & 1.99 & 1985 & 0.0485 & 0.00368 \\
LM-28 & 9 & 12 & 1.5126 & 43.29 & 3.39 & 1960.2 & 0.022 & 0.00166 \\
LM-28 & 12 & 15 & 2.334 & 81.52 & 6.72 & 1922 & 0.0215 & 0.00295 \\
LM-31 & 0 & 3 & 0.3279 & 10.94 & 3.7 & 1992.5 & 0.03 & 0.00264 \\
LM-31 & 3 & 6 & 0.8283 & 26.01 & 5.14 & 1977.5 & 0.0332 & 0.00411 \\
LM-31 & 6 & 9 & 1.4706 & 39.99 & 7.26 & 1963.5 & 0.0459 & 0.00909 \\
LM-31 & 9 & 12 & 2.6049 & 72.51 & 18.2 & 1931 & 0.0349 & 0.01257 \\
LM-31 & 12 & 15 & 3.0693 & 89.52 & 30.51 & 1914 & 0.0273 & 0.02043 \\
LM-31 & 15 & 18 & 3.6183 & 113.35 & 63.23 & 1890.1 & 0.023 & 0.03225 \\
LM-32 & 0 & 3 & 0.309 & 9.5 & 1.45 & 1994 & 0.0325 & 0.00157 \\
LM-32 & 3 & 6 & 0.6114 & 21.39 & 1.73 & 1982.1 & 0.0254 & 0.00142 \\
LM-32 & 6 & 9 & 1.0938 & 47.36 & 2.77 & 1956.1 & 0.0186 & 0.00122 \\
LM-32 & 9 & 12 & 1.6251 & 81.69 & 6.66 & 1921.8 & 0.0155 & 0.00204 \\
LM-32 & 12 & 15 & 2.1105 & 109.28 & 13.84 & 1894.2 & 0.0176 & 0.00544 \\
LM-50B & 0 & 1 & 0.34 & 4.23 & 3.42 & 1999.6 & 0.0804 & 0.00677 \\
LM-50B & 2 & 3 & 1.62 & 11.43 & 2.84 & 1992.4 & 0.2377 & 0.01871 \\
LM-50B & 4 & 5 & 3.04 & 21.72 & 3.03 & 1982.2 & 0.1162 & 0.00813 \\
LM-50B & 6 & 7 & 4.38 & 36.63 & 3.88 & 1967.2 & 0.082 & 0.00769 \\
LM-50B & 8 & 9 & 5.52 & 54.7 & 5.82 & 1949.2 & 0.0574 & 0.00856 \\
LM-50B & 10 & 11 & 6.585 & 73.7 & 8.99 & 1930.2 & 0.0561 & 0.01351 \\
LM-50B & 12 & 13 & 8.305 & 108.88 & 23.23 & 1895 & 0.0457 & 0.02432 \\
\hline & & & & & & & & \\
\hline
\end{tabular}


TABLE A-6 TC, TN, TP accumulation rates.

Core Top of Interval Base of Interval Sed.acum.rate TC

TN

TP

\begin{tabular}{|c|c|c|c|c|c|c|}
\hline & $(\mathbf{c m})$ & $(\mathbf{c m})$ & $\left(\mathrm{g} / \mathrm{cm}^{2} / \mathrm{yr}\right)$ & \multicolumn{3}{|c|}{$\left(\mathbf{m g} / \mathbf{c m}^{2} / \mathbf{y r}\right)\left(\mathbf{m g} / \mathbf{c m}^{2} / \mathbf{y r}\right)\left(\mathbf{m g} / \mathbf{c m}^{2} / \mathbf{y r}\right)$} \\
\hline LM-06 & 0 & 3 & 0.01 & 2.05 & 0.20 & 0.01 \\
\hline LM-06 & 3 & 6 & 0.01 & 0.41 & 0.05 & 0.00 \\
\hline LM-28 & 0 & 3 & 0.04 & 4.33 & 0.52 & 0.04 \\
\hline LM-28 & 3 & 6 & 0.07 & 5.65 & 0.63 & 0.16 \\
\hline LM-28 & 6 & 9 & 0.05 & 3.34 & 0.40 & 0.03 \\
\hline LM-28 & 9 & 12 & 0.02 & 1.80 & 0.22 & 0.02 \\
\hline LM-28 & 12 & 15 & 0.02 & 0.79 & 0.09 & 0.01 \\
\hline LM-31 & 0 & 3 & 0.03 & 3.82 & 0.50 & 0.03 \\
\hline LM-31 & 3 & 6 & 0.03 & 3.34 & 0.36 & 0.03 \\
\hline LM-31 & 6 & 9 & 0.05 & 8.20 & 0.65 & 0.02 \\
\hline LM-31 & 9 & 12 & 0.03 & 11.35 & 0.87 & 0.01 \\
\hline LM-31 & 12 & 15 & 0.03 & 10.60 & 0.83 & 0.00 \\
\hline LM-31 & 15 & 18 & 0.02 & 9.81 & 0.77 & 0.00 \\
\hline LM-32 & 0 & 3 & 0.03 & 3.75 & 0.44 & 0.04 \\
\hline LM-32 & 3 & 6 & 0.03 & 2.78 & 0.31 & 0.03 \\
\hline LM-32 & 6 & 9 & 0.02 & 1.83 & 0.18 & 0.02 \\
\hline LM-32 & 9 & 12 & 0.02 & 0.98 & 0.09 & 0.02 \\
\hline LM-32 & 12 & 15 & 0.02 & 0.72 & 0.06 & 0.00 \\
\hline LM-45 & 0 & 3 & 0.01 & 0.79 & 0.11 & 0.01 \\
\hline LM-50 & 0 & 3 & 0.08 & 7.17 & 1.02 & 0.08 \\
\hline LM-50 & 0 & 3 & 0.24 & 27.36 & 3.92 & 0.25 \\
\hline LM-50 & 3 & 6 & 0.12 & 14.40 & 1.55 & 0.14 \\
\hline LM-50 & 6 & 9 & 0.08 & 8.67 & 1.23 & 0.09 \\
\hline LM-50 & 9 & 12 & 0.06 & 6.30 & 0.88 & 0.06 \\
\hline LM-50 & 12 & 15 & 0.06 & 4.66 & 0.64 & 0.04 \\
\hline LM-50 & 15 & 18 & 0.05 & 2.76 & 0.34 & 0.03 \\
\hline LM-50 & 18 & 21 & 0.10 & 3.75 & 0.50 & 0.04 \\
\hline LM-50 & 21 & 24 & 0.08 & 3.55 & 0.61 & 0.03 \\
\hline LM-50 & 24 & 27 & 0.12 & 4.88 & 0.58 & 0.09 \\
\hline LM-50 & 30 & 33 & 0.15 & 7.66 & 0.64 & 0.14 \\
\hline LM-50 & 33 & 36 & 0.20 & 17.13 & 1.42 & 0.13 \\
\hline
\end{tabular}


TABLE A-7 Lake Monroe ${ }^{137}$ Cs activity results from selected intervals for cores LM-28, LM-31, LM-32.

\begin{tabular}{ccccccc}
\hline Core & $\begin{array}{c}\text { Top of } \\
\text { Interval } \\
(\mathbf{c m})\end{array}$ & $\begin{array}{c}\text { Base of } \\
\text { Interval } \\
(\mathbf{c m})\end{array}$ & $\begin{array}{c}\text { Tube ht. } \\
(\mathbf{c m})\end{array}$ & $\begin{array}{c}{ }^{137} \mathbf{C s} \\
(\mathbf{p C i} / \mathbf{g})\end{array}$ & $\begin{array}{c}\text { S.D. }{ }^{137} \mathbf{C s} \\
(\mathbf{p C i} / \mathbf{g})\end{array}$ & $\begin{array}{c}{ }^{137} \mathbf{C s} \text { Corr. } \\
(\mathbf{p C i} / \mathbf{g})\end{array}$ \\
\hline LM-28 & 3 & 6 & 1.5 & 0.86 & 0.09 & 0.63 \\
LM-28 & 6 & 9 & 1.3 & 0.84 & 0.07 & 0.6 \\
LM-28 & 9 & 12 & 1.2 & 1.02 & 0.06 & 0.73 \\
LM-28 & 12 & 15 & 1.3 & 0.32 & 0.06 & 0.23 \\
LM-28 & 15 & 18 & 1.2 & N.D. & N.D. & 0 \\
LM-28 & 21 & 24 & 1.2 & N.D. & N.D. & 0 \\
LM-31 & 3 & 6 & 1.3 & 1.24 & 0.1 & 0.89 \\
LM-31 & 6 & 9 & 1.5 & 0.44 & 0.06 & 0.33 \\
LM-31 & 9 & 12 & 1 & 0.17 & 0.04 & 0.13 \\
LM-31 & 12 & 15 & 2.1 & N.D. & N.D. & 0 \\
LM-31 & 21 & 24 & 1.4 & N.D. & N.D. & 0 \\
LM-32 & 0 & 3 & 0.5 & 1.84 & 0.16 & 1.32 \\
LM-32 & 3 & 6 & 0.9 & 1.78 & 0.15 & 1.3 \\
LM-32 & 6 & 9 & 1.1 & 1.68 & 0.17 & 1.25 \\
LM-32 & 9 & 12 & 1 & 0.24 & 0.09 & 0.18 \\
LM-32 & 12 & 15 & 1.2 & N.D. & N.D. & 0 \\
LM-32 & 15 & 18 & 1.1 & N.D. & N.D. & 0 \\
LM-32 & 18 & 21 & 1.1 & N.D. & N.D. & 0 \\
\hline & & & & & & \\
\hline
\end{tabular}


TABLE A-8 Lake Monroe stable isotope data for selected six cores (LM06, LM-31, LM-32, LM-45, LM-50).

\begin{tabular}{|c|c|c|c|c|}
\hline Core & $\begin{array}{c}\text { Top of } \\
\text { Interval } \\
(\mathrm{cm}) \\
\end{array}$ & $\begin{array}{c}\text { Base of } \\
\text { Interval } \\
(\mathrm{cm}) \\
\end{array}$ & $\begin{array}{c}\delta^{15} \mathrm{~N} \\
(\mathrm{AIR}) \\
\end{array}$ & $\begin{array}{c}\delta^{13} \mathrm{C} \\
\text { (VPDB) }\end{array}$ \\
\hline LM-06 & 0 & 3 & 3.78 & -25.33 \\
\hline LM-06 & 3 & 6 & 4.16 & -24.88 \\
\hline LM-06 & 6 & 9 & 4.14 & -25.07 \\
\hline LM-06 & 9 & 12 & 3.94 & -26.49 \\
\hline LM-06 & 12 & 15 & 3.56 & -26.42 \\
\hline LM-06 & 15 & 18 & 3.35 & -26.13 \\
\hline LM-06 & 18 & 21 & 3.22 & -26.55 \\
\hline LM-06 & 21 & 24 & 3 & -26.49 \\
\hline LM-06 & 24 & 27 & 3.22 & -26.34 \\
\hline LM-06 & 27 & 30 & 3.13 & -26.3 \\
\hline LM-06 & 30 & 33 & 2.99 & -26.1 \\
\hline LM-06 & 33 & 36 & 2.74 & -26.37 \\
\hline LM-06 & 36 & 39 & 2.64 & -26.28 \\
\hline LM-06 & 39 & 42 & 2.46 & -26 \\
\hline LM-06 & 42 & 45 & 2.32 & -26.3 \\
\hline LM-06 & 45 & 48 & 2.29 & -26.34 \\
\hline LM-06 & 48 & 51 & 2.41 & -26.66 \\
\hline LM-06 & 51 & 54 & 2.46 & -26.98 \\
\hline LM-06 & 54 & 57 & 2.41 & -26.72 \\
\hline LM-06 & 57 & 60 & 2.74 & -26.21 \\
\hline LM-28 & 0 & 3 & 3.72 & -24.2 \\
\hline LM-28 & 3 & 6 & 3.9 & -24.06 \\
\hline LM-28 & 6 & 9 & 3.56 & -24.3 \\
\hline LM-28 & 9 & 12 & 3.65 & -24.23 \\
\hline LM-28 & 12 & 15 & 3.61 & -24.61 \\
\hline LM-28 & 15 & 18 & 4.26 & -25.07 \\
\hline LM-28 & 18 & 21 & 3.9 & -25.73 \\
\hline LM-28 & 21 & 24 & 4.07 & -25.99 \\
\hline LM-28 & 24 & 27 & 4.23 & -26.16 \\
\hline LM-28 & 27 & 30 & 3.37 & -25.99 \\
\hline LM-28 & 30 & 33 & 3.58 & -26.15 \\
\hline LM-28 & 33 & 36 & 3.54 & -26.49 \\
\hline LM-28 & 36 & 39 & 4.55 & -26.06 \\
\hline LM-28 & 39 & 42 & 4.42 & -26.13 \\
\hline LM-28 & 42 & 45 & 3.68 & -25.82 \\
\hline LM-31 & 0 & 3 & 3.39 & -24.05 \\
\hline LM-31 & 3 & 6 & 3.55 & -23.9 \\
\hline LM-31 & 6 & 9 & 3.77 & -25.97 \\
\hline LM-31 & 9 & 12 & 3.56 & -26.44 \\
\hline LM-31 & 12 & 15 & 3.70 & -26.54 \\
\hline LM-31 & 15 & 18 & 3.22 & -26.33 \\
\hline LM-31 & 18 & 21 & 3.02 & -26.12 \\
\hline LM-31 & 21 & 24 & 3.13 & -26.33 \\
\hline
\end{tabular}




\begin{tabular}{|c|c|c|c|c|}
\hline \multicolumn{5}{|c|}{ TABLE A-8 (continued) } \\
\hline LM-31 & 24 & 27 & 3.74 & -26.40 \\
\hline LM-31 & 27 & 30 & 3.85 & -26.50 \\
\hline LM-31 & 30 & 33 & 3.54 & -26.31 \\
\hline LM-31 & 33 & 36 & 3.49 & -26.46 \\
\hline LM-31 & 36 & 39 & 2.94 & -26.58 \\
\hline LM-31 & 39 & 42 & 2.76 & -26.99 \\
\hline LM-31 & 42 & 45 & 3.38 & -26.68 \\
\hline LM-31 & 45 & 48 & 3.18 & -26.75 \\
\hline LM-31 & 48 & 51 & 2.99 & -26.69 \\
\hline LM-31 & 51 & 54 & 3.52 & -26.30 \\
\hline LM-31 & 54 & 57 & 3.97 & -26.29 \\
\hline LM-32 & 0 & 3 & 3.23 & -24.61 \\
\hline LM-32 & 3 & 6 & 3.50 & -24.38 \\
\hline LM-32 & 6 & 9 & 3.83 & -23.77 \\
\hline LM-32 & 9 & 12 & 3.77 & -23.85 \\
\hline LM-32 & 12 & 15 & 3.62 & -25.08 \\
\hline LM-32 & 15 & 18 & 3.57 & -25.98 \\
\hline LM-32 & 18 & 21 & 3.66 & -25.80 \\
\hline LM-32 & 21 & 24 & 3.71 & -25.95 \\
\hline LM-32 & 24 & 27 & 3.53 & -26.00 \\
\hline LM-32 & 27 & 30 & 3.73 & -26.16 \\
\hline LM-32 & 30 & 33 & 3.68 & -26.41 \\
\hline LM-32 & 33 & 36 & 3.16 & -26.24 \\
\hline LM-32 & 36 & 39 & 3.41 & -25.94 \\
\hline LM-32 & 39 & 42 & 3.08 & -26.28 \\
\hline LM-32 & 42 & 45 & 3.16 & -26.04 \\
\hline LM-32 & 45 & 48 & 3.25 & -26.05 \\
\hline LM-32 & 48 & 51 & 3.48 & -26.15 \\
\hline LM-32 & 51 & 54 & 3.22 & -26.32 \\
\hline LM-32 & 54 & 57 & 3.42 & -26.22 \\
\hline LM-32 & 57 & 60 & 3.32 & -26.33 \\
\hline LM-32 & 60 & 63 & 3.65 & -26.31 \\
\hline LM-32 & 63 & 66 & 3.74 & -26.46 \\
\hline LM-32 & 66 & 69 & 3.63 & -26.17 \\
\hline LM-32 & 70 & 70 & 3.75 & -26.13 \\
\hline LM-45 & 0 & 3 & 3.54 & -23.80 \\
\hline LM-45 & 3 & 6 & 3.71 & -23.85 \\
\hline LM-45 & 6 & 9 & 4.08 & -24.52 \\
\hline LM-45 & 9 & 12 & 4.24 & -26.00 \\
\hline LM-45 & 12 & 15 & 4.12 & -26.71 \\
\hline LM-45 & 15 & 18 & 4.36 & -26.82 \\
\hline LM-45 & 18 & 21 & 4.12 & -27.09 \\
\hline LM-45 & 21 & 24 & 3.83 & -26.58 \\
\hline LM-45 & 24 & 27 & 3.69 & -26.81 \\
\hline LM-45 & 27 & 30 & 3.56 & -26.34 \\
\hline LM-45 & 30 & 33 & 3.88 & -26.47 \\
\hline LM-45 & 33 & 36 & 3.39 & -26.60 \\
\hline LM-45 & 36 & 39 & 3.44 & -26.23 \\
\hline
\end{tabular}




\begin{tabular}{|c|c|c|c|c|}
\hline \\
\hline \multicolumn{5}{|c|}{$\begin{array}{cc}\text { 1ABLE A-8 (continued) } \\
\text { LM-45 }\end{array}$} \\
\hline LM-50 & 0 & 3 & 3.15 & -24.08 \\
\hline LM-50 & 3 & 6 & 2.96 & -24.63 \\
\hline LM-50 & 6 & 9 & 2.54 & -24.86 \\
\hline LM-50 & 9 & 12 & 2.90 & -24.72 \\
\hline LM-50 & 12 & 15 & 2.97 & -24.07 \\
\hline LM-50 & 15 & 18 & 3.58 & -23.52 \\
\hline LM-50 & 18 & 21 & 3.91 & -23.49 \\
\hline LM-50 & 21 & 24 & 3.53 & -23.70 \\
\hline LM-50 & 24 & 27 & 3.55 & -23.50 \\
\hline LM-50 & 27 & 30 & 3.02 & -24.17 \\
\hline LM-50 & 30 & 33 & 3.29 & -25.87 \\
\hline LM-50 & 33 & 36 & 3.91 & -26.87 \\
\hline LM-50 & 36 & 39 & 3.49 & -27.28 \\
\hline LM-50 & 39 & 42 & 3.05 & -27.04 \\
\hline LM-50 & 42 & 45 & 3.38 & -27.36 \\
\hline LM-50 & 45 & 48 & 3.11 & -27.05 \\
\hline LM-50 & 48 & 51 & 3.10 & -26.81 \\
\hline LM-50 & 51 & 54 & 2.98 & -26.96 \\
\hline LM-50 & 54 & 57 & & -26.41 \\
\hline
\end{tabular}

